\title{
Synthesis of Spiro[4.5]trienones by Intramolecular ipso-Halocyclization
}

\section{of 4-(p-Methoxyaryl)-1-alkynes}

Xiaoxia Zhang, Richard C. Larock ${ }^{*}$

Department of Chemistry, Iowa State University, Ames, Iowa 50011

\section{Supporting Information}

General. The ${ }^{1} \mathrm{H}$ and ${ }^{13} \mathrm{C}$ NMR spectra were recorded at 300 and $75.5 \mathrm{MHz}$ or 400 and $100 \mathrm{MHz}$ respectively. All melting points are uncorrected. High resolution mass spectra were recorded on a Kratos MS50TC double focusing magnetic sector mass spectrometer using $\mathrm{EI}$ at $70 \mathrm{eV}$. All reagents were used directly as obtained commercially unless otherwise noted.

\section{Synthesis of Starting Materials.}

Compounds $\mathbf{1}, \mathbf{5}, \mathbf{7}, \mathbf{9}$, and 13 were prepared by the following general reaction conditions. To a solution of $N$-(4-methoxyphenyl)trifluoromethanesulfonamide ${ }^{1}(1.28 \mathrm{~g}$, $5.0 \mathrm{mmol}), \mathrm{PPh}_{3}(5.5 \mathrm{mmol})$ and the corresponding propargylic alcohol $(5.5 \mathrm{mmol})$ in anhydrous THF $(50 \mathrm{~mL})$ at $0{ }^{\circ} \mathrm{C}$ was added diethyl azodicarboxylate $(5.5 \mathrm{mmol})$. The resulting solution was stirred at $0{ }^{\circ} \mathrm{C}$ for $1 \mathrm{~h}$ and an additional $3 \mathrm{~h}$ at room temperature. The mixture was washed with brine $(50 \mathrm{~mL})$ and the organic layer was dried over $\mathrm{Na}_{2} \mathrm{SO}_{4}$, filtered, and the solvent removed under reduced pressure. The residue was purified by chromatography on a silica gel column to afford the corresponding product.

\section{$N$-(4-Methoxyphenyl)- $N$-(3-phenylprop-2-yn-1-}

yl)trifluoromethanesulfonamide (1). The indicated compound was prepared as a yellow oil from 3-phenyl-2-propyn-1-ol in a $70 \%$ yield. The reaction mixture was 
chromatographed using 5:1 hexane/EtOAc. ${ }^{1} \mathrm{H} \mathrm{NMR}\left(\mathrm{CDCl}_{3}, 300 \mathrm{MHz}\right) \delta 3.78(\mathrm{~s}, 3 \mathrm{H})$, $4.70(\mathrm{~s}, 2 \mathrm{H}), 6.91-6.94(\mathrm{~m}, 2 \mathrm{H}), 7.29-7.41(\mathrm{~m}, 7 \mathrm{H}) ;{ }^{13} \mathrm{C} \mathrm{NMR}\left(\mathrm{CDCl}_{3}, 75 \mathrm{MHz}\right) \delta 44.76$, $55.72,82.35,86.90,114.98,122.18,128.68,129.20,129.63,130.96,131.95,160.65$; IR $\left(\mathrm{CH}_{2} \mathrm{Cl}_{2}\right)$ 3060, 3008, 2967, 2938, $2841 \mathrm{~cm}^{-1}$; HRMS $\mathrm{m} / \mathrm{z} 369.0651$ (calcd for $\left.\mathrm{C}_{17} \mathrm{H}_{14} \mathrm{~F}_{3} \mathrm{NO}_{3} \mathrm{~S}, 369.0646\right)$.

\section{$N$-(4-Methoxyphenyl)- $N$-[3-(4-methoxyphenyl)prop-2-yn-1-}

yl)trifluoromethanesulfonamide (5). The indicated compound was prepared as an orange oil from 3-(4-methoxyphenyl)-2-propyn-1-ol in a $98 \%$ yield. The reaction mixture was chromatographed using 5:1 hexane/EtOAc. ${ }^{1} \mathrm{H}$ NMR $\left(\mathrm{CDCl}_{3}, 400 \mathrm{MHz}\right) \delta$ $3.73(\mathrm{~s}, 3 \mathrm{H}), 3.74(\mathrm{~s}, 3 \mathrm{H}), 4.66(\mathrm{~s}, 2 \mathrm{H}), 6.79-6.82(\mathrm{~d}, J=9.0 \mathrm{~Hz}, 2 \mathrm{H}), 6.88-6.91(\mathrm{~d}, J=$ $8.7 \mathrm{~Hz}, 2 \mathrm{H}), 7.28-7.31(\mathrm{~d}, J=8.7 \mathrm{~Hz}, 2 \mathrm{H}), 7.36-7.39(\mathrm{~d}, J=9.0 \mathrm{~Hz}, 2 \mathrm{H}) ;{ }^{13} \mathrm{C}$ NMR $\left(\mathrm{CDCl}_{3}, 75 \mathrm{MHz}\right) \delta 44.84,55.42,55.61,80.99,86.93,114.19,114.90,129.66,130.95$, 133.44, 160.38, 160.63; IR $\left(\mathrm{CH}_{2} \mathrm{Cl}_{2}\right) 2963,2842,2220,1606,1508,1390 \mathrm{~cm}^{-1}$; HRMS $\mathrm{m} / z 399.0758$ (calcd for $\mathrm{C}_{18} \mathrm{H}_{16} \mathrm{~F}_{3} \mathrm{NO}_{4} \mathrm{~S}, 399.0752$ ).

\section{$N$-[3-(4-Acetylphenyl)prop-2-yn-1-yl]- $N$-(4-}

methoxyphenyl)trifluoromethanesulfonamide (7). The indicated compound was prepared as a yellow oil from 1-[4-(3-hydroxy-1-propynyl)phenyl]ethanone in a $95 \%$ yield. The reaction mixture was chromatographed using 3:1 hexane/EtOAc. ${ }^{1} \mathrm{H}$ NMR $\left(\mathrm{CDCl}_{3}, 300 \mathrm{MHz}\right) \delta 2.54(\mathrm{~s}, 3 \mathrm{H}), 3.77(\mathrm{~s}, 1 \mathrm{H}), 4.74(\mathrm{~s}, 2 \mathrm{H}), 6.92-6.95(\mathrm{~d}, J=9.0 \mathrm{~Hz}$, 2H), 7.39-7.45 (m, 4H), 7.86-7.89 (d, $J=9.0 \mathrm{~Hz}, 2 \mathrm{H}) ;{ }^{13} \mathrm{C} \mathrm{NMR}\left(\mathrm{CDCl}_{3}, 75 \mathrm{MHz}\right) \delta$ $21.05,44.61,60.48,85.59,85.94,114.95,118.24,122.53,126.74,128.43,129.42$, 130.83, 131.97, 136.98, 160.65, 197.27 (extra peak due to F splitting); IR $\left(\mathrm{CHCl}_{3}\right) 3057$, 
2971, 2846, 1682, 1606, 1511, $1398 \mathrm{~cm}^{-1}$; HRMS $\mathrm{m} / \mathrm{z} 411.0759$ (calcd for $\left.\mathrm{C}_{19} \mathrm{H}_{16} \mathrm{~F}_{3} \mathrm{NO}_{4} \mathrm{~S}, 411.0752\right)$.

$N$-(2-Heptynyl)- $N$-(4-methoxyphenyl)trifluoromethanesulfonamide (9). The indicated compound was prepared as a colorless oil from 2-heptyn-1-ol in a $80 \%$ yield. The reaction mixture was chromatographed using 10:1 hexane/EtOAc. ${ }^{1} \mathrm{H} \mathrm{NMR}\left(\mathrm{CDCl}_{3}\right.$, $300 \mathrm{MHz}) \delta$ 0.87-0.92 (t, $J=7.2 \mathrm{~Hz}, 3 \mathrm{H}), 1.28-1.49(\mathrm{~m}, 4 \mathrm{H}), 2.13-2.19(\mathrm{~m}, 2 \mathrm{H}), 3.79(\mathrm{~s}$, $3 \mathrm{H}), 4.47(\mathrm{~s}, 2 \mathrm{H}), 6.90-6.95(\mathrm{~d}, J=7.2 \mathrm{~Hz}, 2 \mathrm{H}), 7.32-7.37(\mathrm{~d}, J=7.2 \mathrm{~Hz}, 2 \mathrm{H}) ;{ }^{13} \mathrm{C}$ NMR $\left(\mathrm{CDCl}_{3}, 75 \mathrm{MHz}\right) \delta 13.63,18.40,21.96,30.55,44.39,55.57,73.22,87.84,113.99$, $114.73,118.28,122.57,126.86,129.61,130.86,160.49$ (extra peaks are due to Fsplitting); IR $\left(\mathrm{CH}_{2} \mathrm{Cl}_{2}\right)$ 2962, 2872, 2236, 1607, 1513, $1395 \mathrm{~cm}^{-1}$; HRMS m/z 349.0965 (calcd for $\mathrm{C}_{15} \mathrm{H}_{18} \mathrm{~F}_{3} \mathrm{NO}_{3} \mathrm{~S}, 349.0959$ ).

\section{$N$-[3-(Cyclohex-1-en-1-yl)-1-methylprop-2-ynyl]- $N$-(4-}

methoxyphenyl)trifluoromethanesulfonamide (13). The indicated compound was prepared as a light yellow oil from 4-(1-cyclohexen-1-yl)-3-butyn-2-ol in an $84 \%$ yield. The reaction mixture was chromatographed using 5:1 hexane/EtOAc. ${ }^{1} \mathrm{H} \mathrm{NMR}\left(\mathrm{CDCl}_{3}\right.$, $400 \mathrm{MHz}) \delta 1.37-1.39(\mathrm{~d}, J=7.2 \mathrm{~Hz}, 3 \mathrm{H}), 1.55-1.63(\mathrm{~m}, 4 \mathrm{H}), 2.05-2.08(\mathrm{~m}, 4 \mathrm{H}), 3.80(\mathrm{~s}$, $3 \mathrm{H}), 5.25-5.26(\mathrm{q}, J=7.2 \mathrm{~Hz}, 1 \mathrm{H}), 6.06(\mathrm{~s}, 1 \mathrm{H}), 6.90-6.93(\mathrm{~d}, J=8.8 \mathrm{~Hz}, 2 \mathrm{H}), 7.32-7.34$ $(\mathrm{d}, J=8.8 \mathrm{~Hz}, 2 \mathrm{H}) ;{ }^{13} \mathrm{C} \mathrm{NMR}\left(\mathrm{CDCl}_{3}, 100 \mathrm{MHz}\right) \delta 21.39,21.97,22.16,25.57,25.62$, $28.82,50.30,55.42,83.81,88.10,114.13,118.58,119.80,121.79,125.50,132.91$, 135.70, 160.55 (extra peaks due to F splitting); IR $\left(\mathrm{CH}_{2} \mathrm{Cl}_{2}\right) 2985,2936,2838,2224$, $1731,1512,1386 \mathrm{~cm}^{-1}$; HRMS m/z 387.1121 (calcd for $\mathrm{C}_{18} \mathrm{H}_{20} \mathrm{~F}_{3} \mathrm{NO}_{3} \mathrm{~S}, 387.1116$ ).

$N$-(4-Methoxyphenyl)- $N$-[3-(trimethylsilyl)prop-2-yn-1-

yl)]trifluoromethanesulfonamide (11). To a solution of (3-bromo-1- 
propynyl)trimethylsilane in $\mathrm{CH}_{3} \mathrm{CN}$ was added 4 equiv of 4-methoxyaniline. After being stirred for $20 \mathrm{~h}$ under $\mathrm{N}_{2}$, the reaction was quenched by adding brine. The reaction mixture was extracted with $\mathrm{Et}_{2} \mathrm{O}$. The extracts were dried over $\mathrm{MgSO}_{4}$ and the solvent was removed under reduced pressure. The residue was purified by flash chromatography (5:1 hexane/EtOAc) on silica gel to afford $N$-[3-(trimethylsilyl)prop-2-yn-1-yl]-4methoxyaniline in a $53 \%$ yield as a yellow oil. To a solution of $N$-[3(trimethylsilyl)prop-2-ynyl]-4-methoxyaniline (699 mg, $3.0 \mathrm{mmol}$ ) and $\mathrm{NEt}_{3}(364 \mathrm{mg}, 3.6$ mmol $)$ in $\mathrm{CH}_{2} \mathrm{Cl}_{2}(5 \mathrm{~mL})$ was added $\mathrm{Tf}_{2} \mathrm{O}(1.02 \mathrm{~g}, 3.6 \mathrm{mmol})$ at $-78{ }^{\circ} \mathrm{C}$. The reaction mixture was quenched with aq $\mathrm{NaHCO}_{3}$ and the reaction mixture was extracted twice with $\mathrm{CH}_{2} \mathrm{Cl}_{2}$. The extracts were dried over $\mathrm{MgSO}_{4}$ and the solvent was removed under reduced pressure. The residue was purified by flash chromatography (5:1 hexane/EtOAc) on silica gel to afford compound $\mathbf{1 1}$ (931 mg, $85 \%$ yield) as a yellow oil. ${ }^{1} \mathrm{H}$ NMR $\left(\mathrm{CDCl}_{3}, 300 \mathrm{MHz}\right) \delta 0.15(\mathrm{~s}, 9 \mathrm{H}), 3.82(\mathrm{~s}, 3 \mathrm{H}), 4.47(\mathrm{~s}, 2 \mathrm{H}), 6.91-6.94(\mathrm{~d}, J=9.0 \mathrm{~Hz}$, $2 \mathrm{H}), 7.34-7.36(\mathrm{~d}, J=9.0 \mathrm{~Hz}, 2 \mathrm{H}) ;{ }^{13} \mathrm{C} \mathrm{NMR}\left(\mathrm{CDCl}_{3}, 75 \mathrm{MHz}\right) \delta 0.00,45.00,56.00$, $93.05,98.72,115.10,118.53,122.81,129.87,131.30,160.93$ (extra peaks due to $\mathrm{F}$ splitting); IR $\left(\mathrm{CH}_{2} \mathrm{Cl}_{2}\right)$ 2963, 2842, 1610, 1515, $1398 \mathrm{~cm}^{-1}$; HRMS m/z 365.0734 (calcd for $\mathrm{C}_{14} \mathrm{H}_{18} \mathrm{~F}_{3} \mathrm{NO}_{3} \mathrm{SSi}, 365.0729$ ).

Compounds 15 and 17 were prepared using the following general reaction conditions. To a solution of the corresponding $N$-arylacetamide $(3.0 \mathrm{mmol})$ in anhydrous THF $(10 \mathrm{~mL})$ was added $\mathrm{NaH}(9.0 \mathrm{mmol}, 60 \%$ dispersion in mineral oil $)$ at room temperature. After being stirred for $15 \mathrm{~min}, 3$-bromo-1-phenyl-1-propyne $(4.5 \mathrm{mmol})$ in $5 \mathrm{ml}$ THF was added dropwise. TLC was used to monitor the completion of the reaction. The reaction was cooled to $0{ }^{\circ} \mathrm{C}$ upon completion and quenched with satd $\mathrm{NH}_{4} \mathrm{Cl}$, and 
extracted twice with EtOAc. The organic layer was washed with water and brine, dried over $\mathrm{MgSO}_{4}$, and concentrated in vacuo. The residue was purified by column chromatography on silica gel to afford the corresponding product.

$N$-(4-Methoxyphenyl)- $N$-(3-phenylprop-2-yn-1-yl)acetamide (15). The indicated compound was prepared as an orange oil from $N$-(4-methoxyphenyl)acetamide in a $55 \%$ yield. The reaction mixture was chromatographed using 1:1 hexane/EtOAc. ${ }^{1} \mathrm{H}$ $\operatorname{NMR}\left(\mathrm{CDCl}_{3}, 400 \mathrm{MHz}\right) \delta 1.81(\mathrm{~s}, 3 \mathrm{H}), 3.75(\mathrm{~s}, 3 \mathrm{H}), 4.62(\mathrm{~s}, 2 \mathrm{H}), 6.87-6.89(\mathrm{~d}, J=8.8$ $\mathrm{Hz}, 2 \mathrm{H}), 7.17-7.21(\mathrm{~m}, 5 \mathrm{H}), 7.28-7.29(\mathrm{~m}, 2 \mathrm{H}) ;{ }^{13} \mathrm{C} \mathrm{NMR}\left(\mathrm{CDCl}_{3}, 100 \mathrm{MHz}\right) \delta 22.44$, $38.98,55.48,83.98,84.85,114.77,122.89,128.24,129.40,131.67,134.98,159.38$, 170.47; IR $\left(\mathrm{CH}_{2} \mathrm{Cl}_{2}\right)$ 3056, 2959, 2935, 2841, 1663, 1514, $1392 \mathrm{~cm}^{-1}$; HRMS m/z 279.1263 (calcd for $\mathrm{C}_{18} \mathrm{H}_{17} \mathrm{NO}_{2}, 279.1259$ ).

\section{$N$-[4-(Dimethylamino)phenyl]- $N$-(3-phenylprop-2-yn-1-yl)acetamide}

(17).

The indicated compound was prepared as a slightly, red sticky oil from $\mathrm{N}$-[4(dimethylamino)phenyl]acetamide in a $52 \%$ yield. The reaction mixture was chromatographed using 2:1 hexane/EtOAc. ${ }^{1} \mathrm{H}$ NMR $\left(\mathrm{CDCl}_{3}, 300 \mathrm{MHz}\right) \delta 1.88(\mathrm{~s}, 3 \mathrm{H})$, $2.96(\mathrm{~s}, 6 \mathrm{H}), 6.68-6.71(\mathrm{~d}, J=6.9 \mathrm{~Hz}, 2 \mathrm{H}), 7.13-7.16(\mathrm{~d}, J=6.9 \mathrm{~Hz}, 2 \mathrm{H}), 7.24-7.26(\mathrm{~m}$, 3H), 7.35-7.38 (m, 2H); ${ }^{13} \mathrm{C} \mathrm{NMR}\left(\mathrm{CDCl}_{3}, 75 \mathrm{MHz}\right) \delta 22.66,39.31,40.69,83.87,85.48$, 112.80, 123.31, 128.34, 128.41. 129.01, 131.20, 131.91, 150.34, 171.13; IR $\left(\mathrm{CH}_{2} \mathrm{Cl}_{2}\right)$

3045, 2919, 2812, 1609, 1661, $1524 \mathrm{~cm}^{-1}$; HRMS m/z 292.1580 (calcd for $\mathrm{C}_{19} \mathrm{H}_{20} \mathrm{~N}_{2} \mathrm{O}$, 292.1576).

1-(4-Methoxyphenyl)-4-phenyl-3-butyn-2-one (18). To a cooled suspension (ice bath) of PCC (4.31 g, $20.0 \mathrm{mmol})$ in $\mathrm{CH}_{2} \mathrm{Cl}_{2}(200 \mathrm{~mL})$ was slowly added a solution of 2-(4-methoxyphenyl)ethanol $(15.0 \mathrm{mmol})$ in $\mathrm{CH}_{2} \mathrm{Cl}_{2}(10 \mathrm{~mL})$. The mixture was stirred 
at that temperature for $2 \mathrm{~h}$, then warmed up to room temperature for another $2 \mathrm{~h}$. The mixture was filtered through celite and the solvent was removed under vacuum. The reaction mixture was chromatographed using 5:1 hexane/EtOAc to give (4methoxyphenyl)acetaldehyde as a colorless oil in a $75 \%$ yield. To a solution of phenylacetylene $(10.0 \mathrm{mmol})$ in anhydrous $30 \mathrm{~mL}$ THF at $0{ }^{\circ} \mathrm{C}$ was added $n$-BuLi $(10$ mmol, $2.5 \mathrm{M}$ in hexane) under $\mathrm{N}_{2}$. The resulting solution was stirred at that temperature for $1 \mathrm{~h}$. Then (4-methoxyphenyl)acetaldehyde $(5.0 \mathrm{mmol}) \mathrm{in} 10 \mathrm{ml}$ of THF was added to the solution under an inert atmosphere. The resulting solution was stirred at room temperature for $2 \mathrm{~h}$. Brine $(30 \mathrm{~mL})$ was then added to quench the reaction and the solution was extracted twice with diethyl ether $(2 \times 30 \mathrm{~mL})$. The solvent was removed under vacuum, and the reaction mixture was chromatographed using 5:1 hexane/EtOAc to obtain 1-(4-methoxyphenyl)-4-phenyl-3-butyn-2-ol as a light orange oil in an $80 \%$ yield. ${ }^{1} \mathrm{H}$ NMR $\left(\mathrm{CDCl}_{3}, 300 \mathrm{MHz}\right) \delta 2.91(\mathrm{~s}, 1 \mathrm{H}), 2.99-3.01(\mathrm{~d}, J=6.3 \mathrm{~Hz}, 2 \mathrm{H}), 3.71$ (s, $3 \mathrm{H}), 4.71(\mathrm{~m}, 1 \mathrm{H}), 6.80-6.83(\mathrm{~d}, J=8.7 \mathrm{~Hz}, 2 \mathrm{H}), 7.16-7.26(\mathrm{~m}, 5 \mathrm{H}), 7.35-7.38(\mathrm{~m}, 2 \mathrm{H})$; ${ }^{13} \mathrm{C} \mathrm{NMR}\left(\mathrm{CDCl}_{3}, 75 \mathrm{MHz}\right) \delta 43.57,55.50,64.07,85.95,90.18,114.09,122.96,128.61$, 128.70, 129.08, 131.21, 131.95, 158.79; IR $\left(\mathrm{CH}_{2} \mathrm{Cl}_{2}\right) 3310,1609 \mathrm{~cm}^{-1} ; \mathrm{HRMS} \mathrm{m} / \mathrm{z}$ 252.1154 (calcd for $\mathrm{C}_{17} \mathrm{H}_{16} \mathrm{O}_{2}, 252.1150$ ). To the solution of 1-(4-methoxyphenyl)-4phenyl-3-butyn-2-ol (2.0 mmol) in $10 \mathrm{~mL}$ of $\mathrm{CH}_{2} \mathrm{Cl}_{2}$ was added Dess-Martin periodinane ( $2.4 \mathrm{mmol})$. The mixture was stirred for $12 \mathrm{~h}$. The reaction was diluted with another 20 $\mathrm{mL}$ of $\mathrm{CH}_{2} \mathrm{Cl}_{2}$. The organic layer was washed with $20 \mathrm{~mL}$ of aq satd $\mathrm{Na}_{2} \mathrm{~S}_{2} \mathrm{O}_{3}, 20 \mathrm{~mL}$ of aq satd $\mathrm{NaHCO}_{3}$ and brine. The organic layer was dried over $\mathrm{MgSO}_{4}$, and concentrated in vacuo. The residue was purified by column chromatography on silica gel by 10:1 hexane/EtOAc to afford compound $\mathbf{1 8}$ in a $90 \%$ yield as a colorless oil. ${ }^{1} \mathrm{H}$ NMR 
$\left(\mathrm{CDCl}_{3}, 400 \mathrm{MHz}\right) 3.78(\mathrm{~s}, 3 \mathrm{H}), 3.86(\mathrm{~s}, 2 \mathrm{H}), 6.89-6.91(\mathrm{~d}, J=8.8 \mathrm{~Hz}, 2 \mathrm{H}), 7.21-7.23(\mathrm{~d}$, $J=8.8 \mathrm{~Hz}, 2 \mathrm{H}), 7.32-7.35(\mathrm{~m}, 2 \mathrm{H}), 7.40-7.47(\mathrm{~m}, 3 \mathrm{H}) ;{ }^{13} \mathrm{C} \mathrm{NMR}\left(\mathrm{CDCl}_{3}, 100 \mathrm{MHz}\right) \delta$

$51.39,55.33,87.82,92.76,114.24,119.93,125.24,128.67,130.87,130.98,133.15$, 159.03, 185.66; IR $\left(\mathrm{CHCl}_{3}\right) 3068,2935,2228,1701,1609,1511 \mathrm{~cm}^{-1} ; \mathrm{HRMS} \mathrm{m} / \mathrm{z}$ 250.0997 (calcd for $\mathrm{C}_{17} \mathrm{H}_{14} \mathrm{O}_{2}, 250.0994$ ).

4-Methoxyphenyl 3-phenyl-2-propynoate (20). To a solution of 4methoxyphenol (10.0 mmol) in $\mathrm{CH}_{2} \mathrm{Cl}_{2}(5 \mathrm{~mL})$ was added 3-phenyl-2-propynoic acid (10.0 mmol), DMAP (1.0 mmol), and a solution of DCC (10 mmol) in $1 \mathrm{~mL}$ of $\mathrm{CH}_{2} \mathrm{Cl}_{2}$ at $0{ }^{\circ} \mathrm{C}$. After $2 \mathrm{~h}$, the precipitate was filtered off and the filtrate was washed with $\mathrm{H}_{2} \mathrm{O}$, dried over $\mathrm{MgSO}_{4}$, and concentrated in vacuo. The product was obtained as a yellow solid in a $62 \%$ yield by direct recrystallization of the mixture. The spectral properties were identical with those previously reported. ${ }^{4}$

$N$-(4-Methoxyphenyl)-3-phenyl-2-propynamide (22). This compound was prepared using the procedure used for compound $\mathbf{2 0}$, except 4-methoxyaniline was used instead of 4-methoxyphenol. Compound $\mathbf{2 2}$ was obtained as a white solid in a $74 \%$ yield. The spectral properties were identical with those previously reported. ${ }^{5}$

4-(4-Phenyl-3-butynyl)anisole (24). This compound was prepared by the Sonogashiro reaction of 4-(3-butynyl)anisole with phenyl iodide. 4-(3-Butynyl)anisole was prepared as follows. $n$-Butyllithium ( $3.3 \mathrm{mmol}, 1.1$ equiv, $2 \mathrm{M}$ in hexanes) was added at $-78{ }^{\circ} \mathrm{C}$ to 1 -trimethylsilyl-1-propyne (3.6 mmol, 1.2 equiv) in dry THF (30 mL). After stirring at $-78{ }^{\circ} \mathrm{C}$ for $2 \mathrm{~h}, 4$-methoxybenzyl iodide $(248 \mathrm{mg}, 3.0 \mathrm{mmol}$ ) in dry THF (10 ml) was added and the mixture was stirred at $-78{ }^{\circ} \mathrm{C}$ for $1 \mathrm{~h}$. The reaction mixture was allowed to reach room temperature and brine $(30 \mathrm{~mL})$ was then added to quench the 
reaction. The solution was extracted twice using diethyl ether $(2 \times 30 \mathrm{~mL})$. The solvent was removed under vacuum to obtain crude [4-(4-methoxyphenyl)-1butynyl]trimethylsilane, which was directly employed in the next step. To the silane was added $20 \mathrm{~mL}$ of methanol and $\mathrm{KOH}(3.6 \mathrm{mmol}, 1.2$ equiv). The solution was stirred overnight, neutralized by adding $1 \mathrm{~N} \mathrm{HCl}$, and extracted with ether. Removal of the solvent and flash chromatography on silica gel using 40:1 hexane/EtOAc afforded 4-(3butynyl)anisole in an $80 \%$ yield as an oil. The spectral properties were identical with those previously reported. ${ }^{2}$ To a solution of $\mathrm{Et}_{3} \mathrm{~N}(30 \mathrm{~mL}), \mathrm{PdCl}_{2}\left(\mathrm{PPh}_{3}\right)_{2}(2 \mathrm{~mol} \%), 3.0$ mmol of 4-(3-butynyl)anisole, and 1.2 equiv of iodobenzene (stirring for $3 \mathrm{~min}$ beforehand) was added $\mathrm{CuI}(1 \mathrm{~mol} \%)$. The reaction mixture was flushed with $\mathrm{Ar}$ and the flask was then sealed. The mixture was stirred at room temperature and the reaction was monitored by TLC to establish completion of the reaction. The resulting solution was filtered, washed with satd aq $\mathrm{NaCl}$ solution, and extracted with diethyl ether. The combined ether fractions were dried over $\mathrm{MgSO}_{4}$ and concentrated under vacuum to yield the crude product, which was purified by flash chromatography on silica gel using 40:1 hexane/EtOAc. The spectral properties were identical with those previously reported. ${ }^{3}$

General Procedure for Iodocyclization by ICl (Conditions A). $0.3 \mathrm{Mmol}$ of the alkyne and $3 \mathrm{~mL}$ of $\mathrm{CH}_{2} \mathrm{Cl}_{2}$ were placed in a vial. Then the vial was sealed, flushed with $\mathrm{N}_{2}$ and cooled to $-78{ }^{\circ} \mathrm{C}$. 2 Equiv of $\mathrm{ICl}$ in $1 \mathrm{~mL}$ of $\mathrm{CH}_{2} \mathrm{Cl}_{2}$ were added dropwise to the vial for 10 minutes. The reaction mixture was stirred at $-78{ }^{\circ} \mathrm{C}$ for another $10-30$ min. The reaction mixture was then quickly quenched with $20 \mathrm{~mL}$ of satd aq $\mathrm{Na}_{2} \mathrm{~S}_{2} \mathrm{O}_{3}$ and extracted twice with EtOAc. The organic layers were dried over $\mathrm{MgSO}_{4}$ and filtered. 
The solvent was evaporated under reduced pressure and the product was isolated by chromatography on a silica gel column.

3-Iodo-4-phenyl-1-trifluoromethanesulfonyl-1-azaspiro[4.5]deca-3,6,9-trien-

8-one (3). The reaction mixture was chromatographed using 5:1 hexane/EtOAc to afford $88 \%$ of the product as a light yellow solid: mp $166-167{ }^{\circ} \mathrm{C} ;{ }^{1} \mathrm{H}$ NMR $\left(\mathrm{CDCl}_{3}, 400 \mathrm{MHz}\right)$ $\delta 4.69(\mathrm{~s}, 2 \mathrm{H}), 6.16-6.19(\mathrm{~d}, J=10.0 \mathrm{~Hz}, 2 \mathrm{H}), 6.81-6.84(\mathrm{~d}, J=10.0 \mathrm{~Hz}, 2 \mathrm{H}), 6.98-7.01$ (m, 2H), 7.28-7.34 (m, 3H); ${ }^{13} \mathrm{C} \mathrm{NMR}\left(\mathrm{CDCl}_{3}, 100 \mathrm{MHz}\right) \delta 63.47,74.19,90.01,128.53$, 129.26, 129.66, 130.40, 131.57, 144.21, 144.34, 183.62; $\mathrm{IR}\left(\mathrm{CH}_{2} \mathrm{Cl}_{2}\right) 3054,2927,2856$, $1675,1400 \mathrm{~cm}^{-1}$; HRMS $\mathrm{m} / z 480.9461$ (calcd for $\mathrm{C}_{16} \mathrm{H}_{11} \mathrm{~F}_{3} \mathrm{INO}_{3} \mathrm{~S}, 480.9457$ ).

3-Iodo-4-(4-methoxyphenyl)-1-trifluoromethanesulfonyl-1-azaspiro[4.5]deca3,6,9-trien-8-one (6). The reaction mixture was chromatographed using 5:1 hexane/EtOAc to afford $84 \%$ of the product as a light yellow solid: mp $140-141{ }^{\circ} \mathrm{C} ;{ }^{1} \mathrm{H}$ NMR $\left(\mathrm{CDCl}_{3}, 400 \mathrm{MHz}\right) \delta 3.78(\mathrm{~s}, 3 \mathrm{H}), 4.69(\mathrm{~s}, 2 \mathrm{H}), 6.19-6.21(\mathrm{~d}, J=10.0 \mathrm{~Hz}, 2 \mathrm{H})$, 6.81-6.85 (m, 4H), 6.95-6.97 (d, $J=10.0 \mathrm{~Hz}, 2 \mathrm{H}), 8.22-8.26(\mathrm{~m}, 2 \mathrm{H}), 8.70(\mathrm{~s}, 1 \mathrm{H}) ;{ }^{13} \mathrm{C}$ NMR $\left(\mathrm{CDCl}_{3}, 100 \mathrm{MHz}\right) \delta 55.25,63.32,74.06,89.97,113.95,118.14,121.36,123.58$, $130.34,130.58,144.01,144.48,160.34,183.71$ (extra peaks due to F splitting); IR $\left(\mathrm{CH}_{2} \mathrm{Cl}_{2}\right)$ 3054, 2955, 2842, 1674, 1511, $1398 \mathrm{~cm}^{-1}$; HRMS m/z 510.9571 (calcd for $\left.\mathrm{C}_{17} \mathrm{H}_{13} \mathrm{~F}_{3} \mathrm{INO}_{4} \mathrm{~S}, 510.9562\right)$.

\section{4-(4-Acetylphenyl)-3-iodo-1-trifluoromethanesulfonyl-1-azaspiro[4.5]deca-}

3,6,9-trien-8-one (8). The reaction mixture was chromatographed using 3:1 hexane/EtOAc to afford $89 \%$ of the product as a white solid: mp $160-161{ }^{\circ} \mathrm{C} ;{ }^{1} \mathrm{H}$ NMR $\left(\mathrm{CDCl}_{3}, 300 \mathrm{MHz}\right) \delta 2.59(\mathrm{~s}, 3 \mathrm{H}), 4.73(\mathrm{~s}, 2 \mathrm{H}), 6.20-6.23(\mathrm{~d}, J=9.9 \mathrm{~Hz}, 2 \mathrm{H}), 6.87-6.90$ $(\mathrm{d}, J=9.9 \mathrm{~Hz}, 2 \mathrm{H}), 7.15-7.17(\mathrm{~d}, J=6.6 \mathrm{~Hz}, 2 \mathrm{H}), 7.15-7.17(\mathrm{~d}, J=6.6 \mathrm{~Hz}, 2 \mathrm{H}) ;{ }^{13} \mathrm{C}$ 
$\operatorname{NMR}\left(\mathrm{CDCl}_{3}, 75 \mathrm{MHz}\right) \delta 26.85,63.79,74.35,90.96,128.61,129.90,130.70,136.43$, 137.89, 143.57, 144.10, 183.53, 197.36; IR $\left(\mathrm{CHCl}_{3}\right) 3056,2926,2856,1676,1394 \mathrm{~cm}^{-1}$; HRMS m/z 522.9572 (calcd for $\mathrm{C}_{18} \mathrm{H}_{13} \mathrm{~F}_{3} \mathrm{INO}_{4} \mathrm{~S}, 522.9562$ ).

4-Butyl-3-iodo-1-trifluoromethanesulfonyl-1-azaspiro[4.5]deca-3,6,9-trien-8one (10). The reaction mixture was chromatographed using 10:1 hexane/EtOAc to afford a $75 \%$ yield of the product as a light yellow solid: mp $118-119{ }^{\circ} \mathrm{C} ;{ }^{1} \mathrm{H}$ NMR $\left(\mathrm{CDCl}_{3}, 400\right.$ MHz) $\delta$ 0.86-0.88 (t, $J=7.2 \mathrm{~Hz}, 3 \mathrm{H}), 1.26-1.38(\mathrm{~m}, 4 \mathrm{H}), 1.83-1.87(\mathrm{~m}, 2 \mathrm{H}), 4.55(\mathrm{~s}, 2 \mathrm{H})$, 6.34-6.37 (d, $J=10.0 \mathrm{~Hz}, 2 \mathrm{H}), 6.68-6.71(\mathrm{~d}, J=10.0 \mathrm{~Hz}, 2 \mathrm{H}) ;{ }^{13} \mathrm{C} \mathrm{NMR}\left(\mathrm{CDCl}_{3}, 100\right.$ MHz) $\delta 13.60,22.80,28.26,30.96,63.11,74.13,86.87,118.08,121.30,130.15,142.78$, 144.90, 184.05 (extra peaks due to F splitting); IR $\left(\mathrm{CH}_{2} \mathrm{Cl}_{2}\right)$ 2978, 2930, 2871, 1676, $1401 \mathrm{~cm}^{-1}$; HRMS m/z 460.9776 (calcd for $\mathrm{C}_{14} \mathrm{H}_{15} \mathrm{~F}_{3} \mathrm{INO}_{3} \mathrm{~S}, 460.9770$ ).

3-Iodo-1-trifluoromethanesulfonyl-4-trimethylsilyl-1-azaspiro[4.5]deca-3,6,9-

trien-8-one (12). The reaction mixture was chromatographed using 3:1 hexane/EtOAc to afford a $58 \%$ yield of the product as a white solid: $\mathrm{mp} 154-155{ }^{\circ} \mathrm{C} ;{ }^{1} \mathrm{H} \mathrm{NMR}\left(\mathrm{CDCl}_{3}, 400\right.$ MHz) $\delta 0.32(\mathrm{~s}, 9 \mathrm{H}), 4.57$ (s, 2H), 6.39-6.42 (d, $J=10.0 \mathrm{~Hz}, 2 \mathrm{H}), 6.57-6.59(\mathrm{~d}, J=10.0$ $\mathrm{Hz}, 2 \mathrm{H}) ;{ }^{13} \mathrm{C} \mathrm{NMR}\left(\mathrm{CDCl}_{3}, 100 \mathrm{MHz}\right) \delta-1.82,62.92,77.30,100.90,118.02,121.24$, 131.28, 144.82, 148.30, 184.14 (extra peaks due to F splitting); $\mathbb{R}\left(\mathrm{CH}_{2} \mathrm{Cl}_{2}\right) 2959,1674$, $1394 \mathrm{~cm}^{-1}$; HRMS m/z 476.9544 (calcd for $\mathrm{C}_{13} \mathrm{H}_{15} \mathrm{~F}_{3} \mathrm{INO}_{3} \mathrm{Si}, 476.9539$ ).

\section{4-(Cyclohex-1-en-1-yl)-3-iodo-1-trifluoromethanesulfonyl-1-}

azaspiro[4.5]deca-3,6,9-trien-8-one (14). The reaction mixture was chromatographed using 10:1 hexane/EtOAc to afford an $83 \%$ yield of the product as a white solid: mp 131-132 ${ }^{\circ} \mathrm{C} ;{ }^{1} \mathrm{H}$ NMR $\left(\mathrm{CDCl}_{3}, 400 \mathrm{MHz}\right) \delta 1.49-1.64(\mathrm{~m}, 7 \mathrm{H}), 1.87-2.02(\mathrm{~m}, 4 \mathrm{H}), 4.87-$ $4.89(\mathrm{~m}, 1 \mathrm{H}), 5.45(\mathrm{~s}, 1 \mathrm{H}), 6.25-6.28(\mathrm{~m}, 2 \mathrm{H}), 6.62-6.73(\mathrm{~m}, 2 \mathrm{H}) ;{ }^{13} \mathrm{C} \mathrm{NMR}\left(\mathrm{CDCl}_{3}, 300\right.$ 
MHz) $\delta 21.22,22.31,25.02,28.42,68.70,74.68,77.27,97.36,129.68,133.25,144.50$, 184.09 (one $\mathrm{sp}^{3}$ carbon missing due to overlap); IR $\left(\mathrm{CH}_{2} \mathrm{Cl}_{2}\right) 2934,1673,1398 \mathrm{~cm}^{-1}$; HRMS m/z 498.9932 (calcd for $\mathrm{C}_{17} \mathrm{H}_{17} \mathrm{~F}_{3} \mathrm{INO}_{3} \mathrm{~S}, 498.9926$ ).

1-Acetyl-3-iodo-4-phenyl-1-azaspiro[4.5]deca-3,6,9-trien-8-one (16). The reaction mixture was chromatographed using EtOAc to afford a $66 \%$ yield of the product as a white solid (conformational isomers). ${ }^{1} \mathrm{H}$ NMR $\left(\mathrm{CDCl}_{3}, 400 \mathrm{MHz}\right) \delta 1.97$ and 2.11 (s, 3H), 4.65 (s, 2H), 6.15-6.17 (d, $J=10.0 \mathrm{~Hz}, 1 \mathrm{H}), 6.21-6.23(\mathrm{~d}, J=10.0 \mathrm{~Hz}, 1 \mathrm{H}), 6.70-$ $6.72(\mathrm{~d}, J=10.0 \mathrm{~Hz}, 1 \mathrm{H}), 6.81-6.84(\mathrm{~d}, J=10.0 \mathrm{~Hz}, 1 \mathrm{H}), 6.96-6.98(\mathrm{~m}, 2 \mathrm{H}), 7.24-7.30$ (m, 3H); ${ }^{13} \mathrm{C} \mathrm{NMR}\left(\mathrm{CDCl}_{3}, 100 \mathrm{MHz}\right) \delta 21.71,22.80,62.52,62.68,71.36,71.77,90.64$, $93.35,128.22,128.33,129.16,129.26,129.39,129.62,130.00,130.53,132.25,132.37$, 143.30, 145.31, 146.73, 146.89, 168.01, 168.97, 183.61, 184.59; IR $\left(\mathrm{CH}_{2} \mathrm{Cl}_{2}\right) 3048,2926$, 2863, 1665, $1394 \mathrm{~cm}^{-1}$; HRMS m/z 391.0076 (calcd for $\mathrm{C}_{17} \mathrm{H}_{14} \mathrm{INO}_{2}, 391.0069$ ).

General Procedure for the Iodo/bromocyclization by $\mathrm{Br}_{2} / \mathrm{I}_{2}$ (Conditions $\mathrm{B}$ ). $0.3 \mathrm{Mmol}$ of the $N$-(2-alkynyl)-4-methoxyanilide, $0.60 \mathrm{mmol}$ of $\mathrm{NaHCO}_{3}$, and $3 \mathrm{~mL}$ of MeCN were placed in a vial. 2 Equiv of $\mathrm{Br}_{2} / \mathrm{I}_{2}$ in $1 \mathrm{~mL}$ of $\mathrm{CH}_{3} \mathrm{CN}$ were added dropwise to the vial. The reaction mixture was stirred for $10 \min \left(\mathrm{Br}_{2}\right)$ or $1-12 \mathrm{~h}\left(\mathrm{I}_{2}\right)$. The reaction mixture was then quenched with $20 \mathrm{~mL}$ of satd aq $\mathrm{Na}_{2} \mathrm{~S}_{2} \mathrm{O}_{3}$ and extracted twice with EtOAc. The organic layers were dried over $\mathrm{MgSO}_{4}$ and filtered. The solvent was evaporated under reduced pressure and the product was isolated by chromatography on a silica gel column.

\section{3-Bromo-4-phenyl-1-trifluoromethanesulfonyl-1-azaspiro[4.5]deca-3,6,9-}

trien-8-one (4). The reaction mixture was chromatographed using 5:1 hexane/EtOAc to afford a $92 \%$ yield of the product as a white solid: $\mathrm{mp} 142-143{ }^{\circ} \mathrm{C} ;{ }^{1} \mathrm{H} \mathrm{NMR}\left(\mathrm{CDCl}_{3}, 300\right.$ 
MHz) $\delta 4.73(\mathrm{~s}, 2 \mathrm{H}), 6.21-6.24(\mathrm{~d}, J=10.2 \mathrm{~Hz}, 2 \mathrm{H}), 6.85-6.88(\mathrm{~d}, J=10.2 \mathrm{~Hz}, 2 \mathrm{H})$, 7.06-7.09 (m, 2H), 7.32-7.35 (m, 3H); ${ }^{13} \mathrm{C} \mathrm{NMR}\left(\mathrm{CDCl}_{3}, 75 \mathrm{MHz}\right) \delta 59.45,74.23$, $115.69,128.55,129.19,129.58,129.70,130.57,138.35,144.12,183.53 ; \mathrm{IR}\left(\mathrm{CH}_{2} \mathrm{Cl}_{2}\right)$ 3054, 2927, 2852, $1676 \mathrm{~cm}^{-1}$; HRMS m/z 432.9602 (calcd for $\mathrm{C}_{16} \mathrm{H}_{11} \mathrm{BrF}_{3} \mathrm{NO}_{3} \mathrm{~S}$, 432.9595).

3-Iodo-4-phenylspiro[4.5]deca-3,6,9-triene-2,8-dione (19). The reaction mixture was chromatographed using 3:1 hexane/EtOAc to afford a $98 \%$ yield of the product as a purple solid: mp $129-131{ }^{\circ} \mathrm{C} ;{ }^{1} \mathrm{H}$ NMR $\left(\mathrm{CDCl}_{3}, 400 \mathrm{MHz}\right) \delta 2.98(\mathrm{~s}, 2 \mathrm{H})$, 6.34-6.37 (d, $J=10.0 \mathrm{~Hz}, 2 \mathrm{H}), 6.81-6.84(\mathrm{~d}, J=10.0 \mathrm{~Hz}, 2 \mathrm{H}), 7.26-7.29(\mathrm{~m}, 2 \mathrm{H}), 7.36-$ $7.42(\mathrm{~m}, 3 \mathrm{H}) ;{ }^{13} \mathrm{C} \mathrm{NMR}\left(\mathrm{CDCl}_{3}, 100 \mathrm{MHz}\right) \delta 43.40,54.30,106.23,127.00,128.60$, 130.47, 130.65, 134.13, 148.87, 176.22, 184.40, 199.41; IR $\left(\mathrm{CH}_{2} \mathrm{Cl}_{2}\right)$ 3058, 2930, 2853, 1732, 1670, $1624 \mathrm{~cm}^{-1}$; HRMS m/z 361.9809 (calcd for $\mathrm{C}_{16} \mathrm{H}_{11} \mathrm{IO}_{2}, 361.9804$ ).

3-Iodo-4-phenyl-1-oxaspiro[4.5]deca-3,6,9-triene-2,8-dione (21). The reaction mixture was chromatographed using 3:1 hexane/EtOAc to afford a 100\% yield of the product as a white solid: $\mathrm{mp} 174-175{ }^{\circ} \mathrm{C} ;{ }^{1} \mathrm{H}$ NMR $\left(\mathrm{CDCl}_{3}, 400 \mathrm{MHz}\right) \delta 6.38-6.41(\mathrm{~d}, J=$ $10.0 \mathrm{~Hz}, 2 \mathrm{H}), 6.67-6.69(\mathrm{~d}, J=10.0 \mathrm{~Hz}, 2 \mathrm{H}), 7.35-7.48(\mathrm{~m}, 5 \mathrm{H}) ;{ }^{13} \mathrm{C} \mathrm{NMR}\left(\mathrm{CDCl}_{3}, 100\right.$ MHz) $\delta 85.17,88.11,127.32,129.04,130.24,131.16,132.08,141.66,166.86,168.66$, 183.60; IR $\left(\mathrm{CH}_{2} \mathrm{Cl}_{2}\right) 3066,2936,1783,1704,1668,1638,1393 \mathrm{~cm}^{-1}$; HRMS m/z 363.9602 (calcd for $\mathrm{C}_{15} \mathrm{H}_{9} \mathrm{IO}_{3}, 362.9597$ ).

3-Iodo-4-phenyl-1-azaspiro[4.5]deca-3,6,9-triene-2,8-dione (23). The reaction mixture was chromatographed using 3:1 hexane/EtOAc to afford a $84 \%$ yield of the product as a white solid: decomposes at $195{ }^{\circ} \mathrm{C} ;{ }^{1} \mathrm{H}$ NMR $\left(d_{6}\right.$-acetone, $\left.400 \mathrm{MHz}\right) \delta 6.24-$ $6.27(\mathrm{~d}, J=10.0 \mathrm{~Hz}, 2 \mathrm{H}), 6.94-6.96(\mathrm{~d}, J=10.0 \mathrm{~Hz}, 2 \mathrm{H}), 7.37-7.43(\mathrm{~m}, 5 \mathrm{H}), 8.23(\mathrm{~s}$, 
$1 \mathrm{H}) ;{ }^{13} \mathrm{C}$ NMR $\left(d_{6}\right.$-acetone, $\left.100 \mathrm{MHz}\right) \delta 66.72,98.99,128.07,128.42,129.58,130.62$, 132.89, 145.73, 160.70, 168.58, 183.79; IR $\left(\mathrm{CH}_{2} \mathrm{Cl}_{2}\right) 3196,3066,1693,1673,1638 \mathrm{~cm}^{-1}$; HRMS m/z 362.9761 (calcd for $\mathrm{C}_{15} \mathrm{H}_{10} \mathrm{INO}_{2}, 362.9756$ ); Anal. Calcd for $\mathrm{C}_{15} \mathrm{H}_{10} \mathrm{INO}_{2}$ : C, 49.61; H, 2.78; N, 3.86; Found: C, 49.35; H, 3.03; N, 4.03.

General Procedure for the Iodo/bromocyclization of 4-(4-phenylbut-3ynyl)anisole (Conditions C). $0.3 \mathrm{Mmol}$ of 4-(4-phenylbut-3-ynyl)anisole, $0.6 \mathrm{mmol}$ of $\mathrm{NaOMe}, 4 \mathrm{~mL}$ of $\mathrm{MeOH}$, and $2 \mathrm{~mL}$ of $\mathrm{CH}_{2} \mathrm{Cl}_{2}$ were placed in a vial and the solution was cooled to $-78{ }^{\circ} \mathrm{C}$. 5 Equiv of $\mathrm{Br}_{2} / \mathrm{ICl}$ in $1 \mathrm{~mL}$ of $\mathrm{CH}_{2} \mathrm{Cl}_{2}$ were added dropwise to the vial. The reaction mixture was stirred for $10 \mathrm{~min}$ and then quickly quenched with $20 \mathrm{~mL}$ of satd aq $\mathrm{Na}_{2} \mathrm{~S}_{2} \mathrm{O}_{3}$ and extracted twice with EtOAc. The organic layers were dried over $\mathrm{MgSO}_{4}$ and filtered. The solvent was evaporated under reduced pressure and the product was isolated by chromatography on a silica gel column.

2-Iodo-1-phenylspiro[4.5]deca-1,6,9-trien-8-one (25). The reaction mixture was chromatographed using 5:1 hexane/EtOAc to afford a $93 \%$ yield of the product as a light yellow solid (Conditions C): $\mathrm{mp} 124-125{ }^{\circ} \mathrm{C} ;{ }^{1} \mathrm{H} \mathrm{NMR}\left(\mathrm{CDCl}_{3}, 400 \mathrm{MHz}\right) \delta 2.32-$ 2.35 (t, $J=7.2 \mathrm{~Hz}, 1 \mathrm{H}), 3.05-3.08(\mathrm{t}, J=7.2 \mathrm{~Hz}, 1 \mathrm{H}), 6.20-6.22(\mathrm{~d}, J=10.0 \mathrm{~Hz}, 2 \mathrm{H})$, 6.88-6.90 (d, $J=10.0 \mathrm{~Hz}, 2 \mathrm{H}), 7.09-7.11(\mathrm{~m}, 2 \mathrm{H}), 7.26-7.28(\mathrm{~m}, 3 \mathrm{H}) ;{ }^{13} \mathrm{C} \mathrm{NMR}\left(\mathrm{CDCl}_{3}\right.$, $100 \mathrm{MHz}) \delta 37.53,43.47,56.86,98.89,128.01,128.20,128.37,129.14,135.69,147.87$, 151.64, 185.57; IR $\left(\mathrm{CH}_{2} \mathrm{Cl}_{2}\right)$ 2944, 2858, $1620 \mathrm{~cm}^{-1}$; HRMS m/z 348.0019 (calcd for $\left.\mathrm{C}_{16} \mathrm{H}_{13} \mathrm{IO}, 348.0011\right)$.

2-Bromo-1-phenylspiro[4.5]deca-1,6,9-trien-8-one (26). The reaction mixture was chromatographed using 5:1 hexane/EtOAc to afford a $98 \%$ yield of the product as a light yellow solid (Conditions C): $\mathrm{mp} 129-130{ }^{\circ} \mathrm{C} ;{ }^{1} \mathrm{H}$ NMR $\left(\mathrm{CDCl}_{3}, 300 \mathrm{MHz}\right) \delta 2.28$ - 
$2.33(\mathrm{t}, J=7.2 \mathrm{~Hz}, 1 \mathrm{H}), 3.00-3.05(\mathrm{t}, J=7.2 \mathrm{~Hz}, 1 \mathrm{H}), 6.22-6.25(\mathrm{~d}, J=10.2 \mathrm{~Hz}, 2 \mathrm{H})$, 6.90-6.94 (d, $J=10.2 \mathrm{~Hz}, 2 \mathrm{H}), 7.16-7.19(\mathrm{~m}, 2 \mathrm{H}), 7.25-7.28(\mathrm{~m}, 3 \mathrm{H}) ;{ }^{13} \mathrm{C} \mathrm{NMR}\left(\mathrm{CDCl}_{3}\right.$, $75 \mathrm{MHz}) \delta 36.17,39.45,56.88,123.52,128.14,128.39,128.54,129.36,134.12,141.37$, 152.23, 185.72; IR $\left(\mathrm{CH}_{2} \mathrm{Cl}_{2}\right) 3038,2944,2858,1665,1620 \mathrm{~cm}^{-1} ; \mathrm{HRMS} \mathrm{m} / z 300.0155$ (calcd for $\mathrm{C}_{16} \mathrm{H}_{13} \mathrm{BrO}, 300.0150$ ); Anal. Calcd for $\mathrm{C}_{16} \mathrm{H}_{13} \mathrm{BrO}$ : C, 63.81; H, 4.35. Found: C, 63.47; H, 4.70.

\section{5,6-Diphenyl-2-(trifluoromethanesulfonyl)spiro[benz[e]isoindoline-1,1'-}

[2.5]cyclohexadien-4'-one (27). To a solution of $3(0.25 \mathrm{mmol})$ in $4 \mathrm{~mL}$ of DMF in a vial was added diphenylacetylene ( $0.50 \mathrm{mmol}), \mathrm{Pd}(\mathrm{OAc})_{2}(5 \mathrm{~mol} \%), n-\mathrm{Bu} 4 \mathrm{NCl}(0.75$ mmol) and $\mathrm{NaOAc}(0.50 \mathrm{mmol})$. The vial was flushed with $\mathrm{N}_{2}$ and closed. The reaction mixture was heated to $100{ }^{\circ} \mathrm{C}$ for $12 \mathrm{~h}$, cooled to room temperature, diluted with $25 \mathrm{ml}$ of ether, washed with $25 \mathrm{~mL}$ of satd aq $\mathrm{NaCl}$, dried over $\mathrm{MgSO}_{4}$ and filtered. The solvent was evaporated under reduced pressure. The reaction mixture was chromatographed using 5:1 hexane/EtOAc to afford a $46 \%$ yield of the product as a yellow solid: mp 254$255^{\circ} \mathrm{C} ;{ }^{1} \mathrm{H} \mathrm{NMR}\left(\mathrm{CDCl}_{3}, 300 \mathrm{MHz}\right) \delta 4.84(\mathrm{~s}, 2 \mathrm{H}), 6.49-6.52(\mathrm{~d}, J=9.0 \mathrm{~Hz}, 2 \mathrm{H}), 6.98-$ $7.05(\mathrm{~m}, 6 \mathrm{H}), 7.16-7.20(\mathrm{~m}, 7 \mathrm{H}), 7.34-7.40(\mathrm{~m}, 2 \mathrm{H}), 7.56-7.59(\mathrm{~m}, 1 \mathrm{H}), 7.72-7.75(\mathrm{~m}$, $1 \mathrm{H}) ;{ }^{13} \mathrm{C} \mathrm{NMR}\left(\mathrm{CDCl}_{3}, 400 \mathrm{MHz}\right) 55.76,71.90,121.49,126.75,127.06,127.32,127.45$, $127.58,127.90,128.39,128.44,128.61,129.22,130.15,130.83,132.78,133.64,134.22$, 137.55, 137.82, 142.01, 145.91, 184.77; IR ( $\left.\mathrm{CHCl}_{3}\right)$ 3061, 2921, 2835, 1674, 1632, 1398

$\mathrm{cm}^{-1}$; HRMS m/z 531.1129 (calcd for $\mathrm{C}_{30} \mathrm{H}_{20} \mathrm{~F}_{3} \mathrm{NO}_{3} \mathrm{~S}, 531.1116$ ). 


\section{References}

(1) Inoue, J.; Cui, Y.-S.; Sakai, O.; Nakamura, Y.; Kogiso, H.; Kador, P. F. Bioorg.

Chem. 2000, 8, 2167.

(2) Satoh, T.; Hayashi, Y.; Yamakawa, K. Bull. Chem. Soc. Jpn. 1993, 66, 1866.

(3) Ma, S.; Wang, L. J. Org. Chem. 1998, 63, 3497.

(4) Shi, Z.; He, C. J. Org. Chem. 2004, 69, 3669.

(5) Barreau, M.; Ponsinet, G. Synthesis, 1987, 262. 
$666^{\circ} \mathrm{C}$

569.

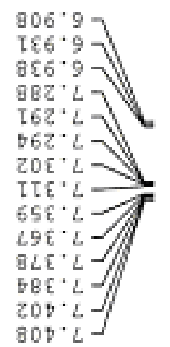

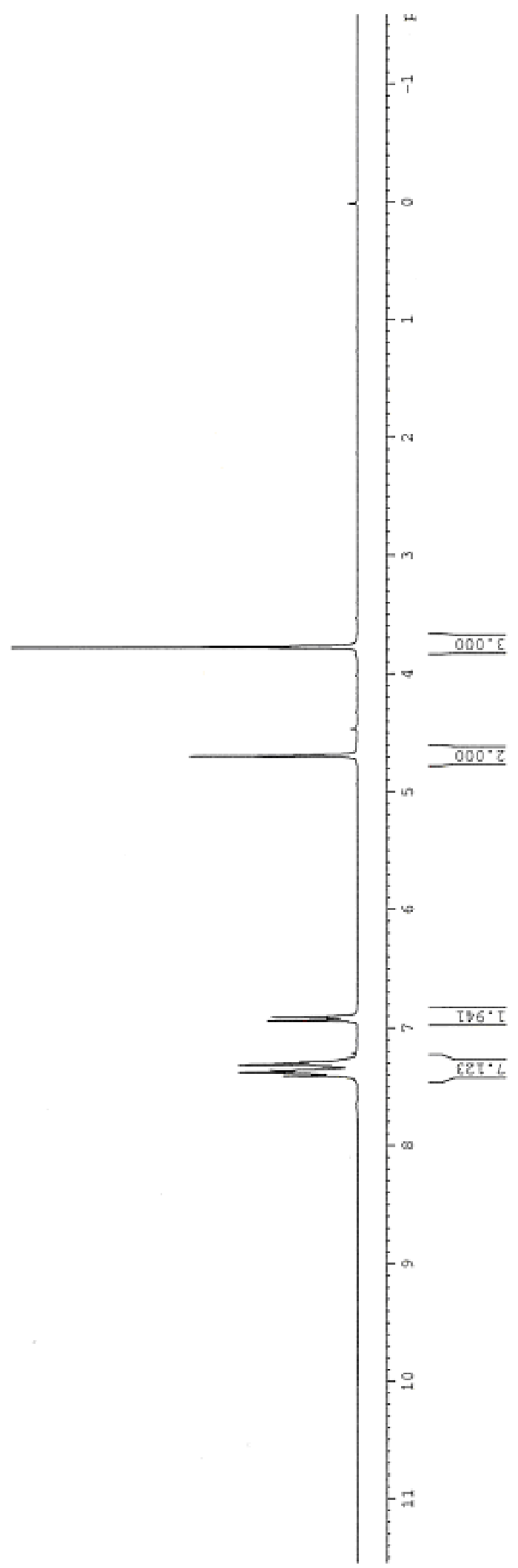

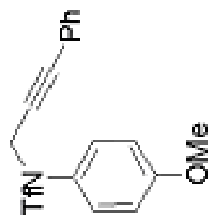



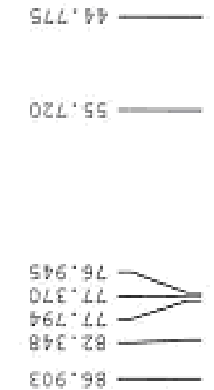

SL6. 71 E9I:2zI 56I. $62 \mathrm{Z}:$ $929 \cdot 621$

ESE. I5T

$059 \cdot 09 \mathrm{\tau}$

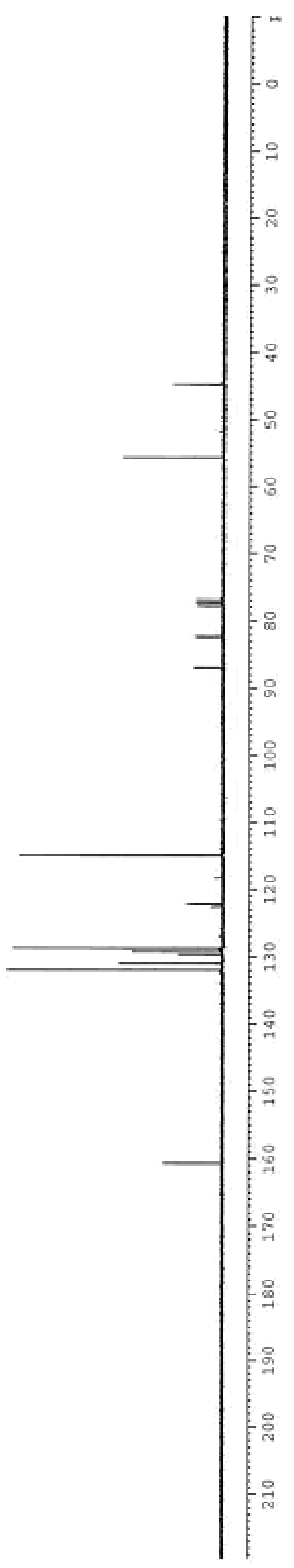

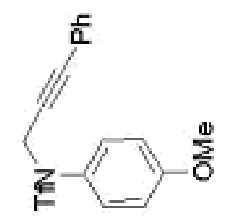



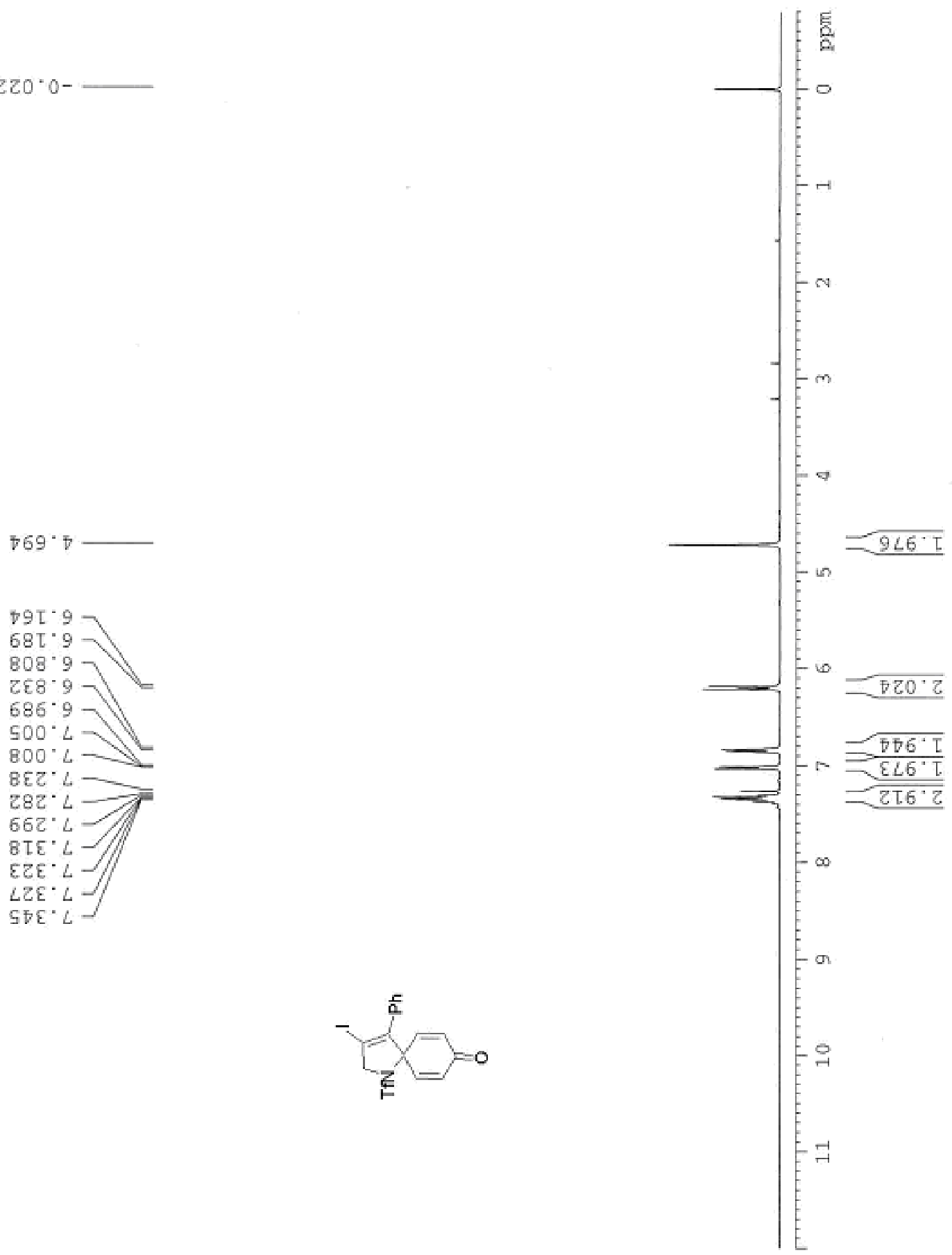

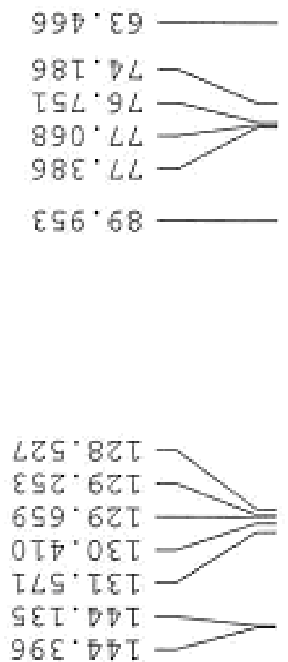

$\varepsilon L S^{\circ} \varepsilon g \tau$
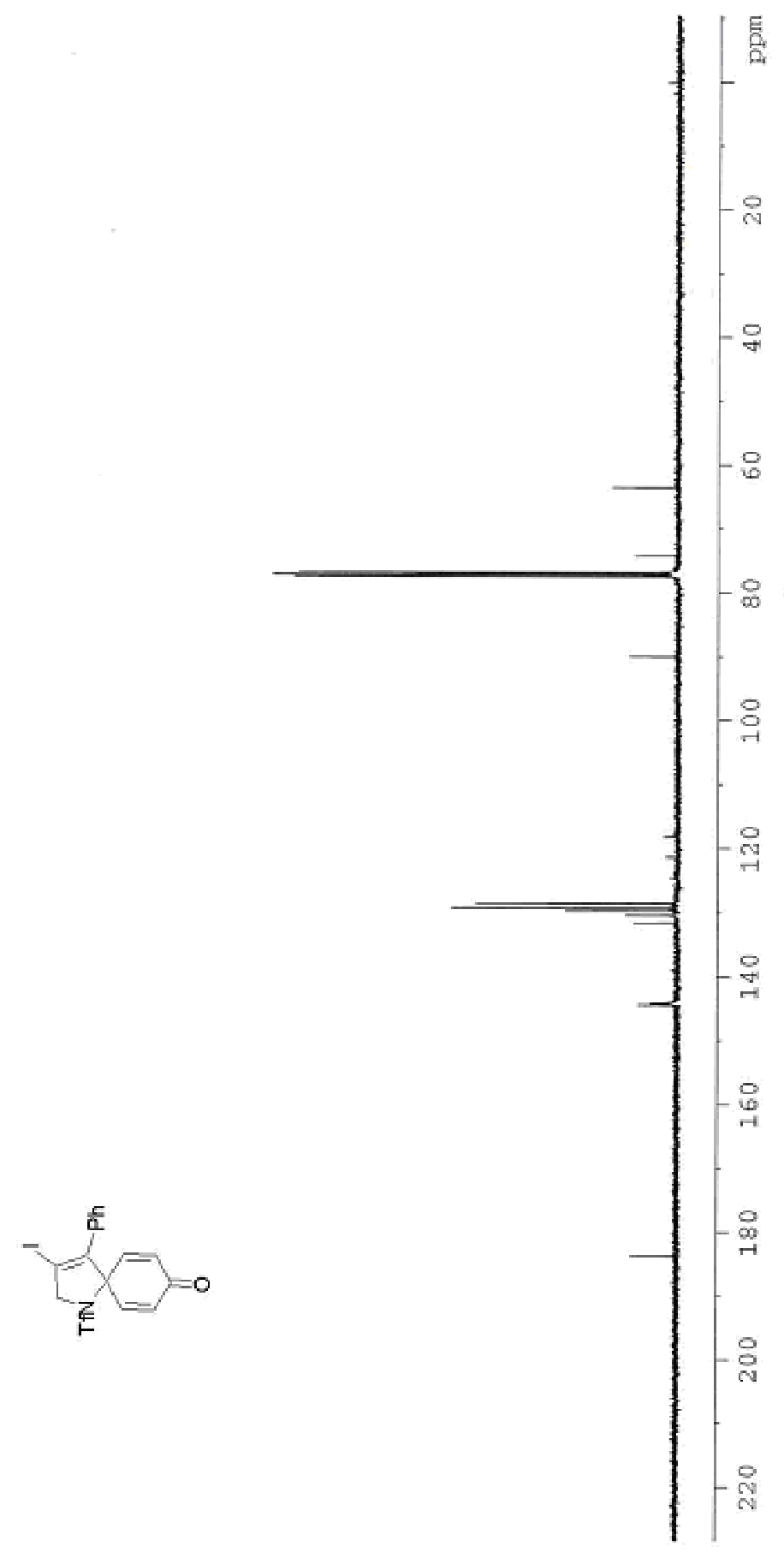
โEL・五

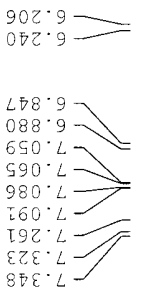

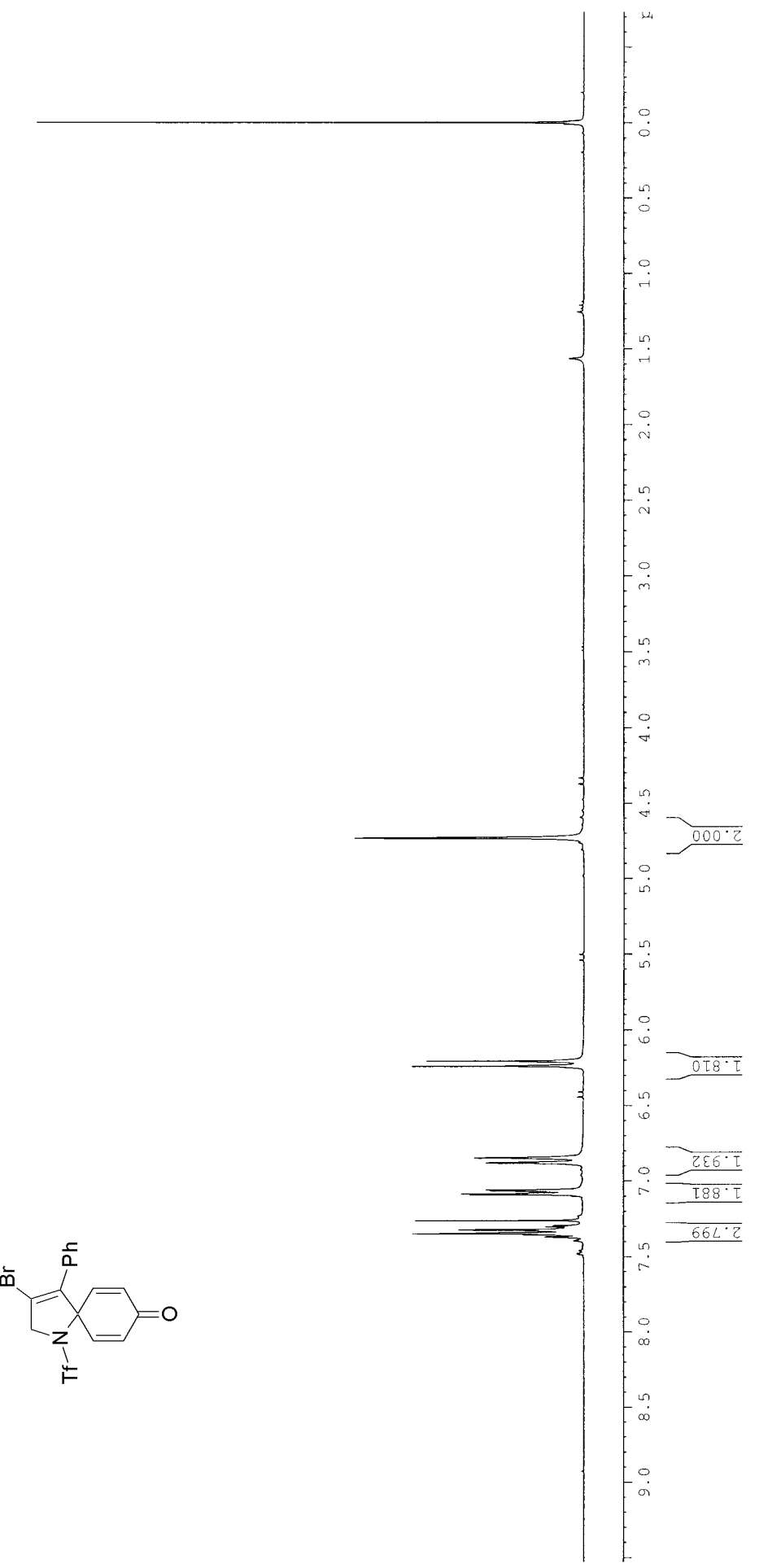




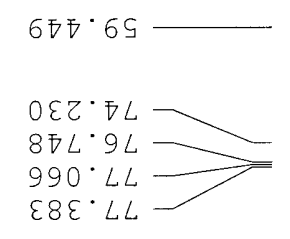

$569^{\circ} \varsigma \tau T$

Sष5.8ZT

$98 I \cdot 62 \tau$

I85. $62 \mathrm{~T}$

$969 \cdot 62 \tau$

ELG' $0 \varepsilon \tau$

โร $8 \varepsilon \tau$

9โโ・五

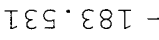

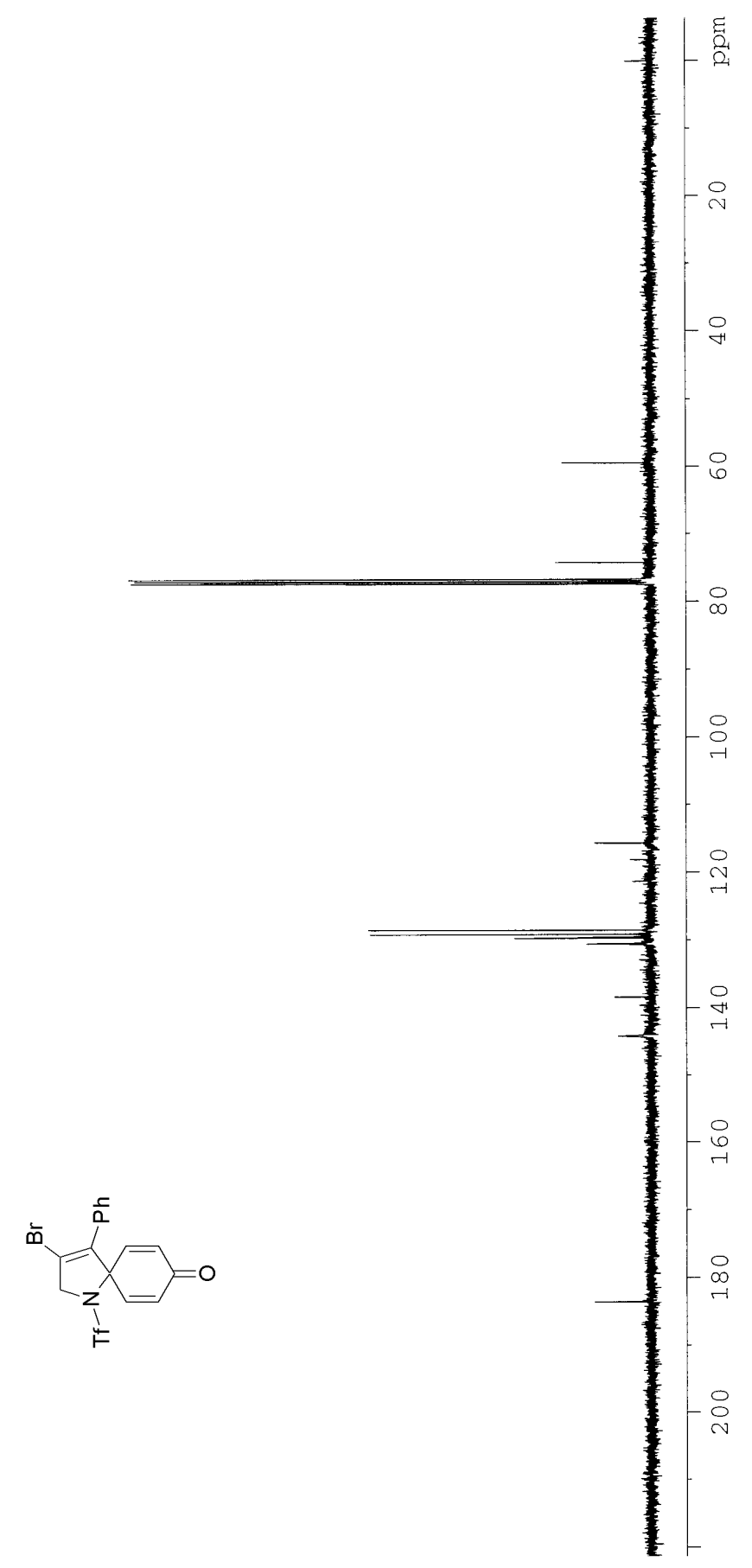

สี 
$000 \cdot 3$

$8 Z L \cdot E-$

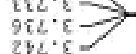

$899^{\circ}+$

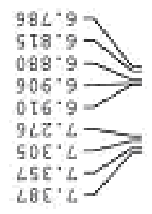

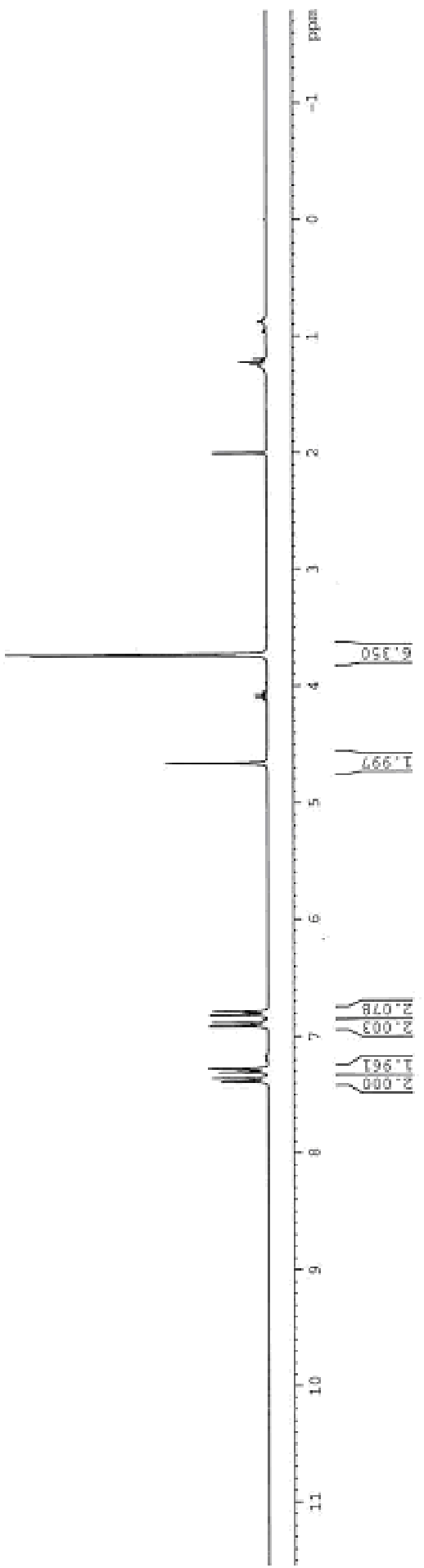


$D D B^{\circ}-60$

$677^{\circ} 55>$
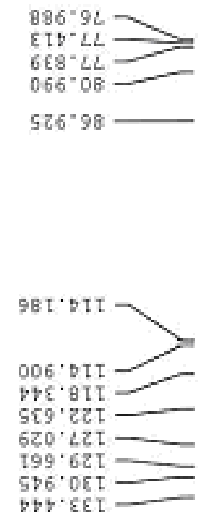

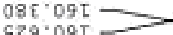

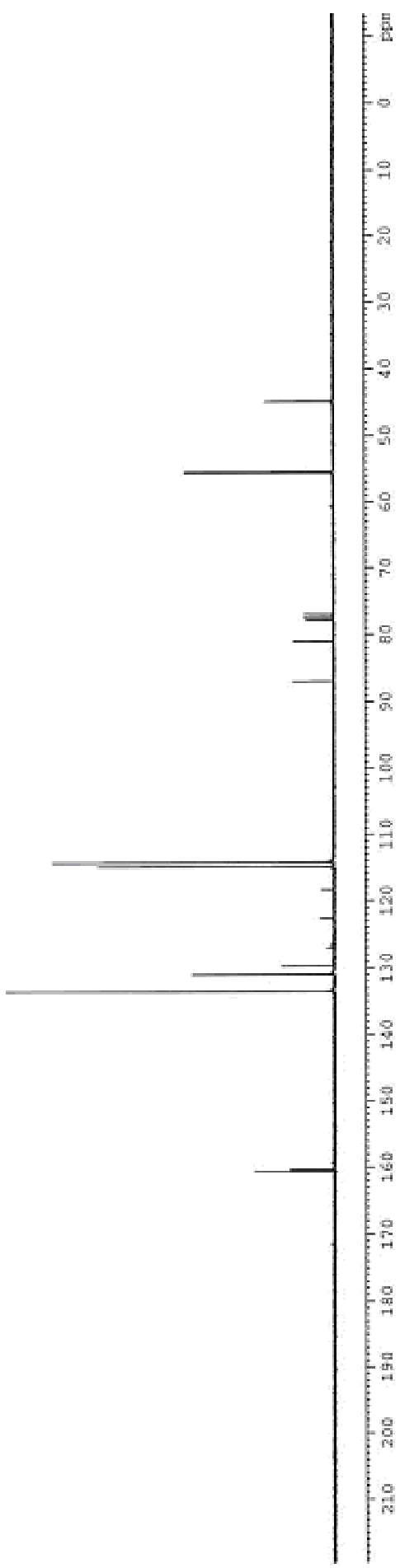


$6 L L^{\circ} \varepsilon$

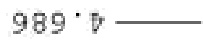

$687 \cdot 9 \longrightarrow$
$7 \tau 2 \cdot 9 \longrightarrow$ हโ8' 9 T28.9५Е8. 9

$978 \cdot 9$

ह56.9DL6. $9=$

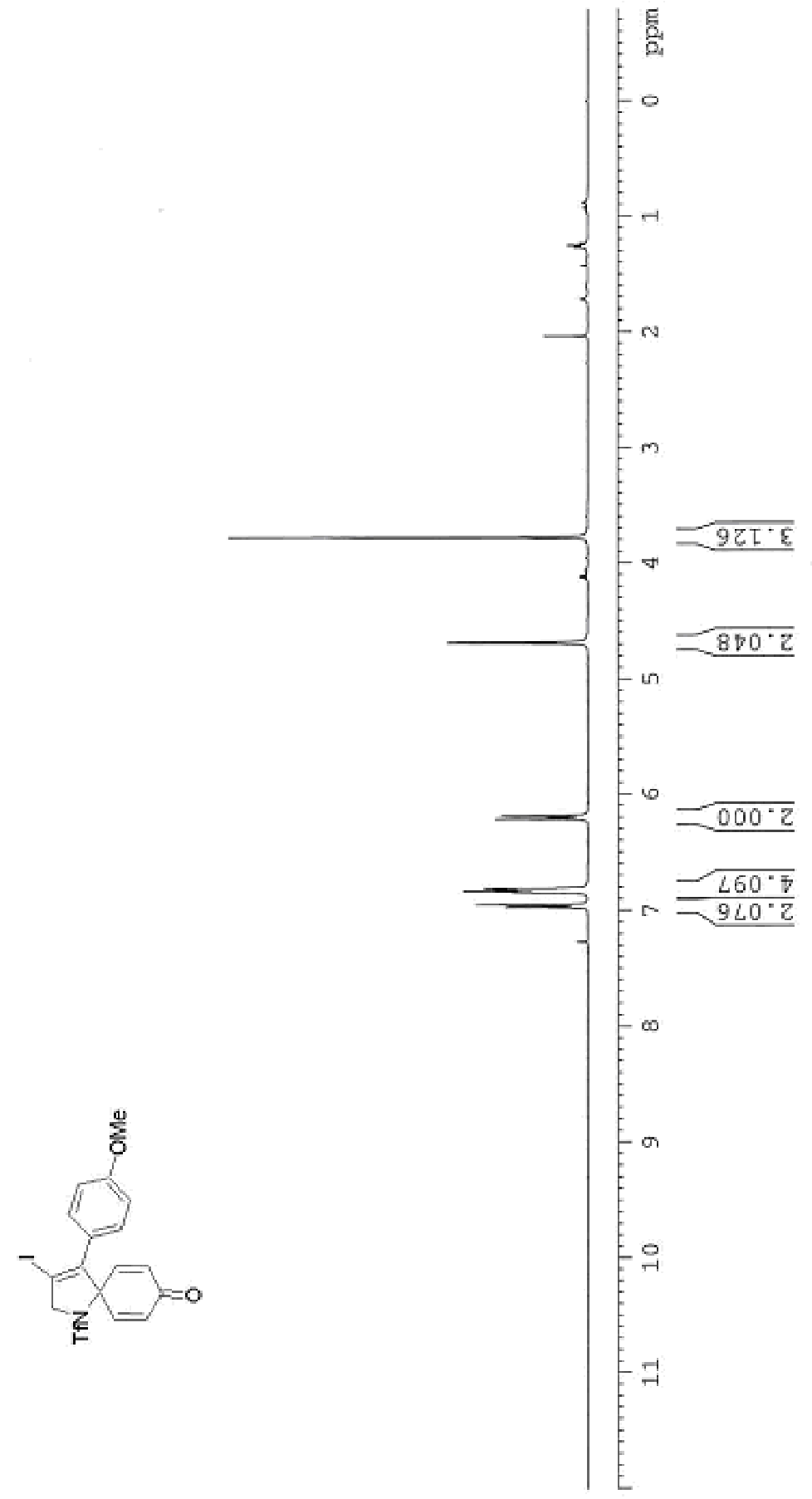




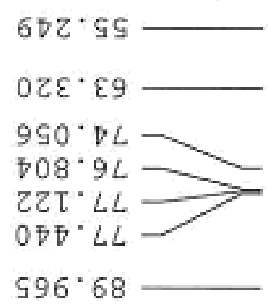

$\nabla 56^{\circ} \varepsilon \mathrm{IT}$

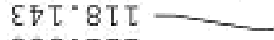

SSE" TZT

8LS' $22 T$

$\nabla \nabla E \cdot D E T$

D $8 S^{\circ} 0 \varepsilon \tau$

$0 \mathrm{TO} \nabla \bar{\nabla} \mathrm{T}$

$\angle L F \cdot \overline{\nabla T T}$

$\varepsilon \overline{E \cdot 09 \tau}$

G०L" $88 \tau$

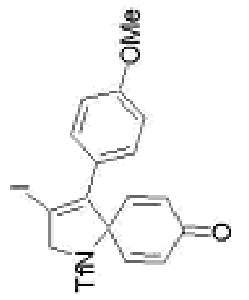

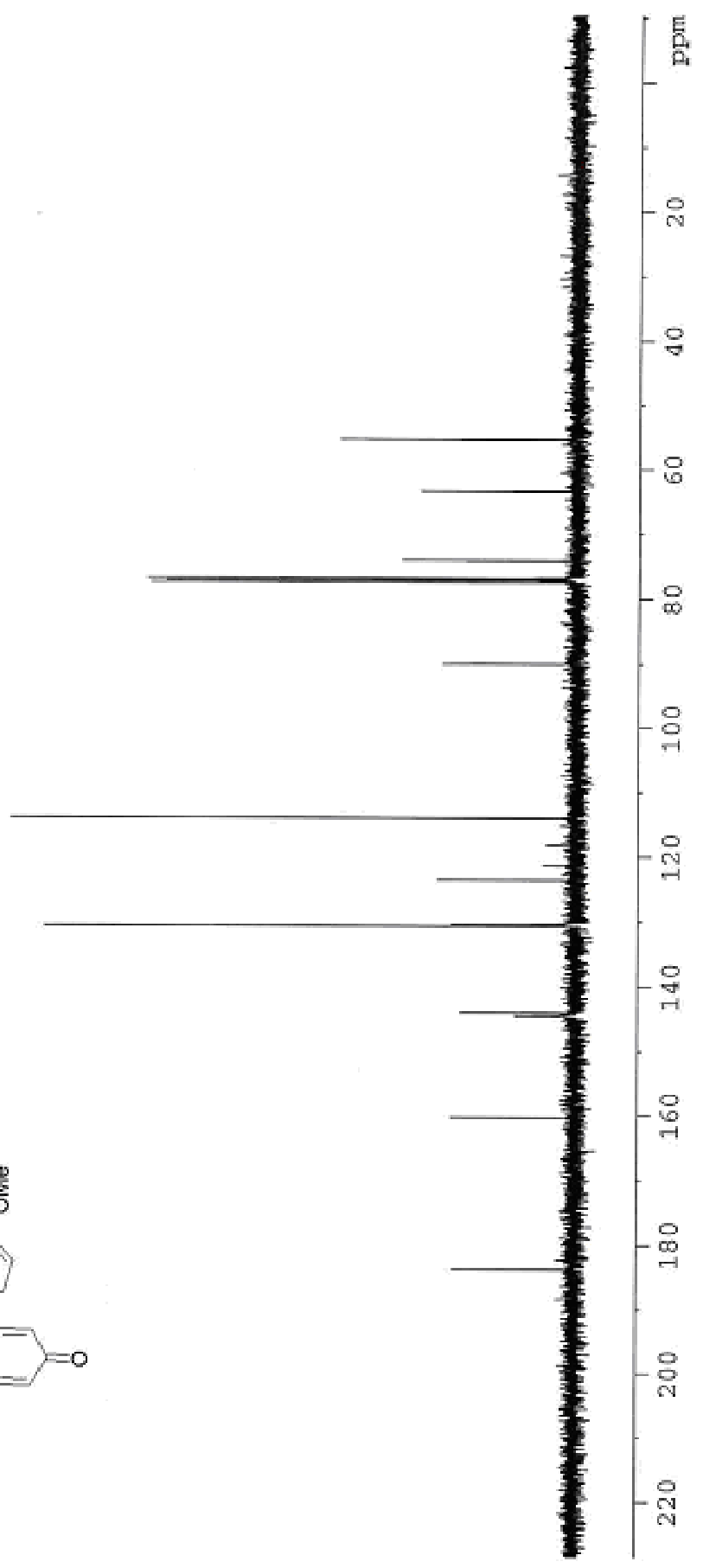


$55 g^{\circ} 2$

$59 L^{\circ} \mathrm{i}-$

$D S L^{-} D$

$024.9-2=$

055 90

$220 \cdot 4 \longrightarrow$

299: $4=$

$0.6-2=$

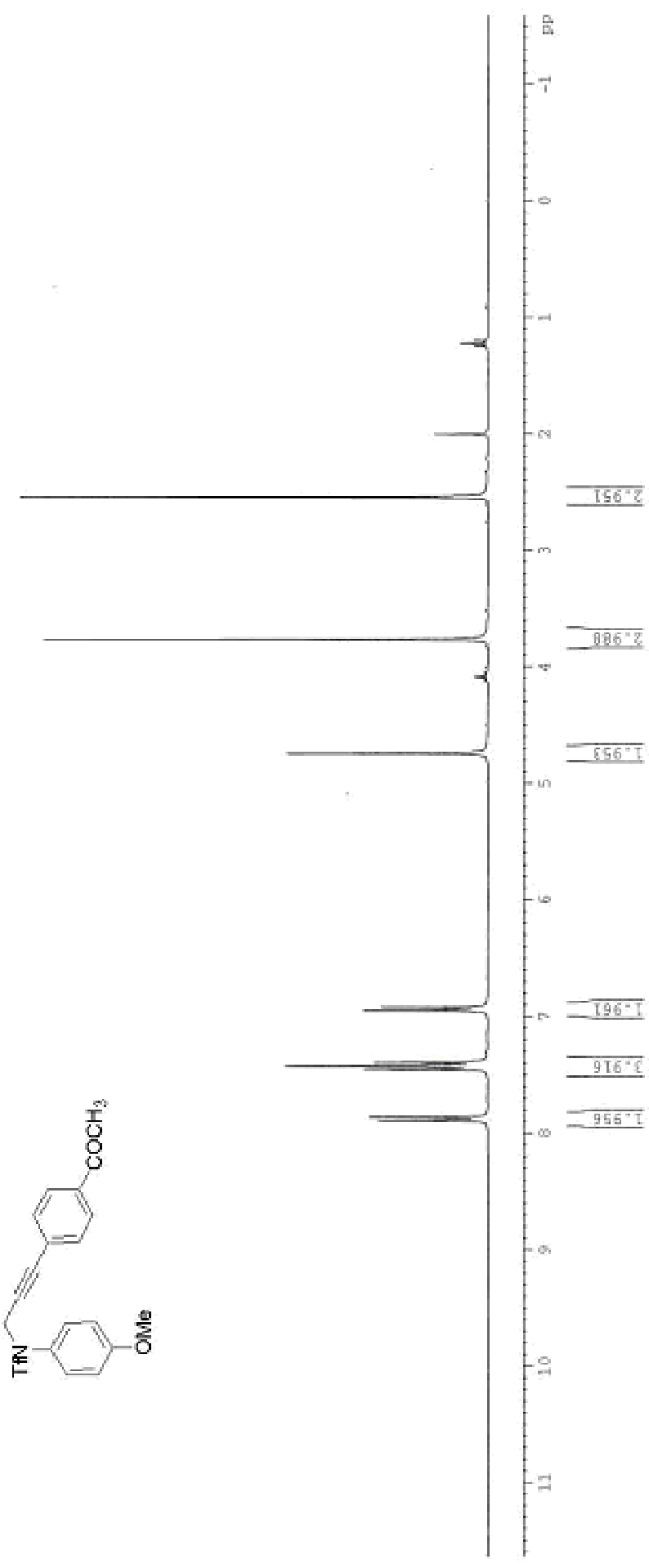



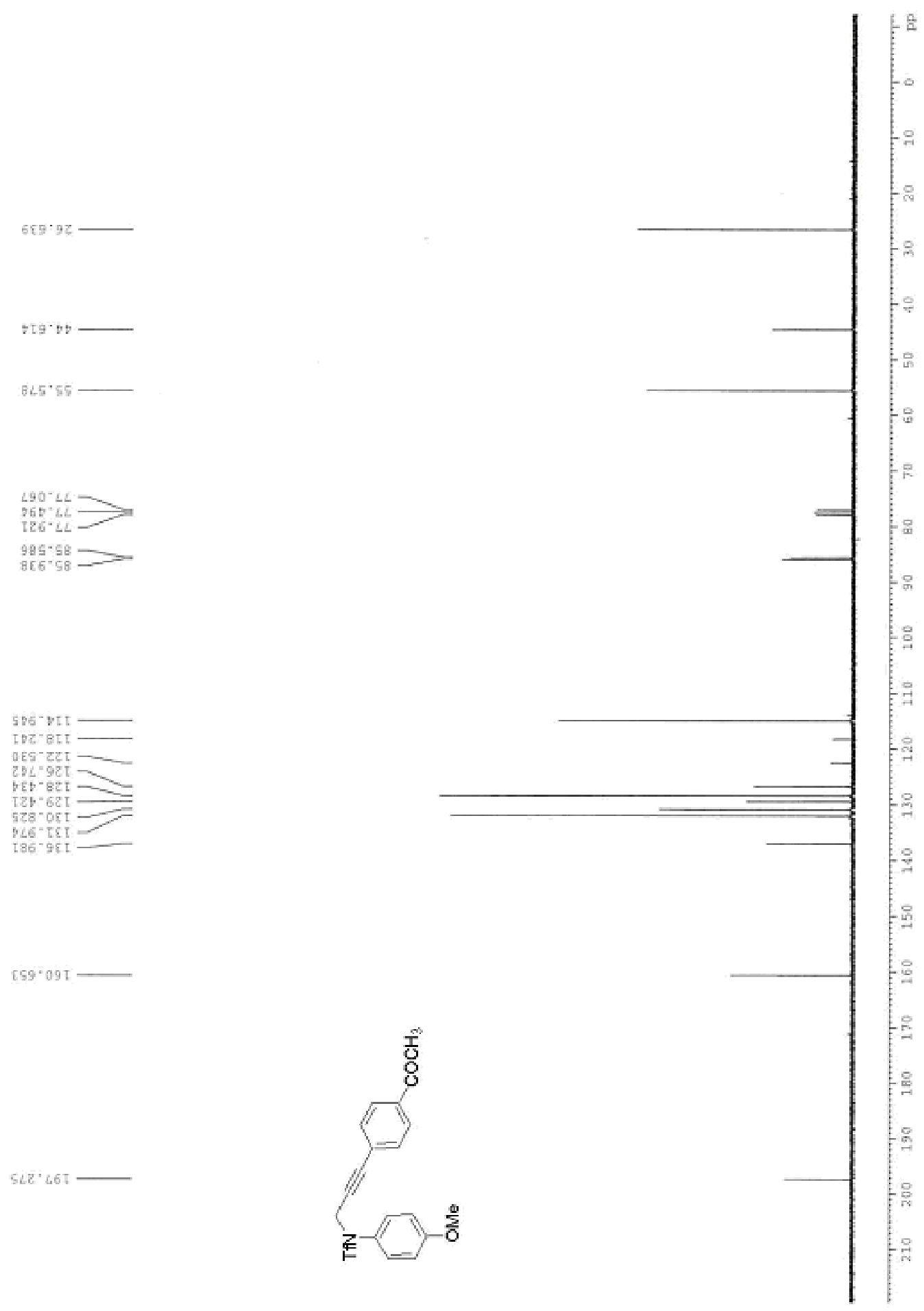

$505-21 t$ TDR- $8 \pi t$

कर्श bEt-ezt

$T 2 \mathrm{~V}=62 \mathrm{~T}$

T28- ort -

7LS-tEt

I85-9EL -

C59"09T -

$5 L Z^{\circ} 66 \mathrm{~T}$ 
$765^{\prime 2}$

$\operatorname{sed} L^{\circ}$

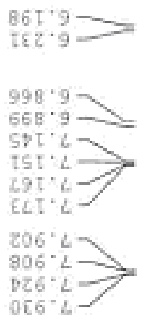

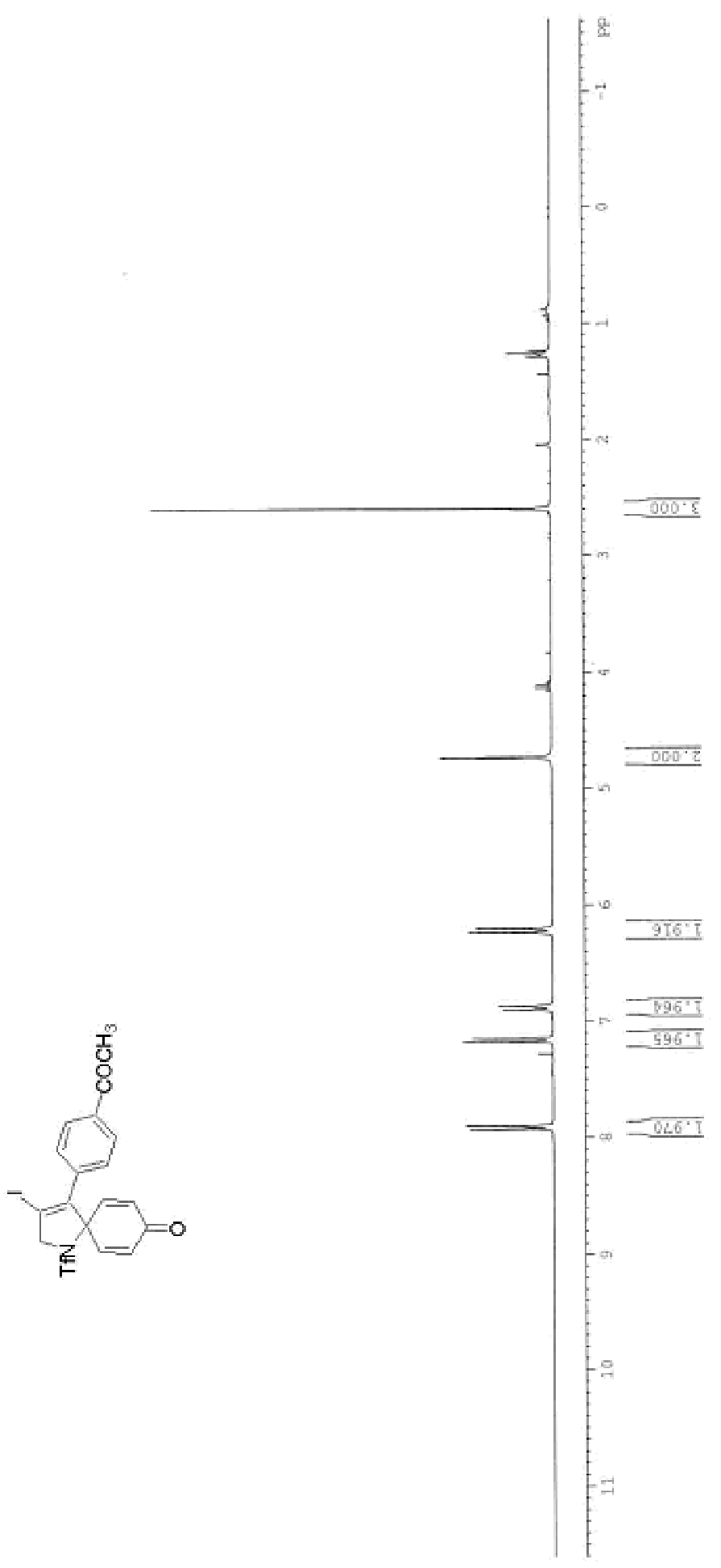

สิ 
$758 \cdot 9 z$

85L' 69

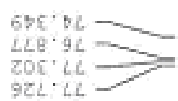

$596^{\prime} 0.6$

T19.82T

206 6t: 205

DEF-95T:

If 6 - LET

ELS. CFI $=$

$925.8 \mathrm{~T}$

$65 \mathrm{E} \cdot 46 \mathrm{t}$

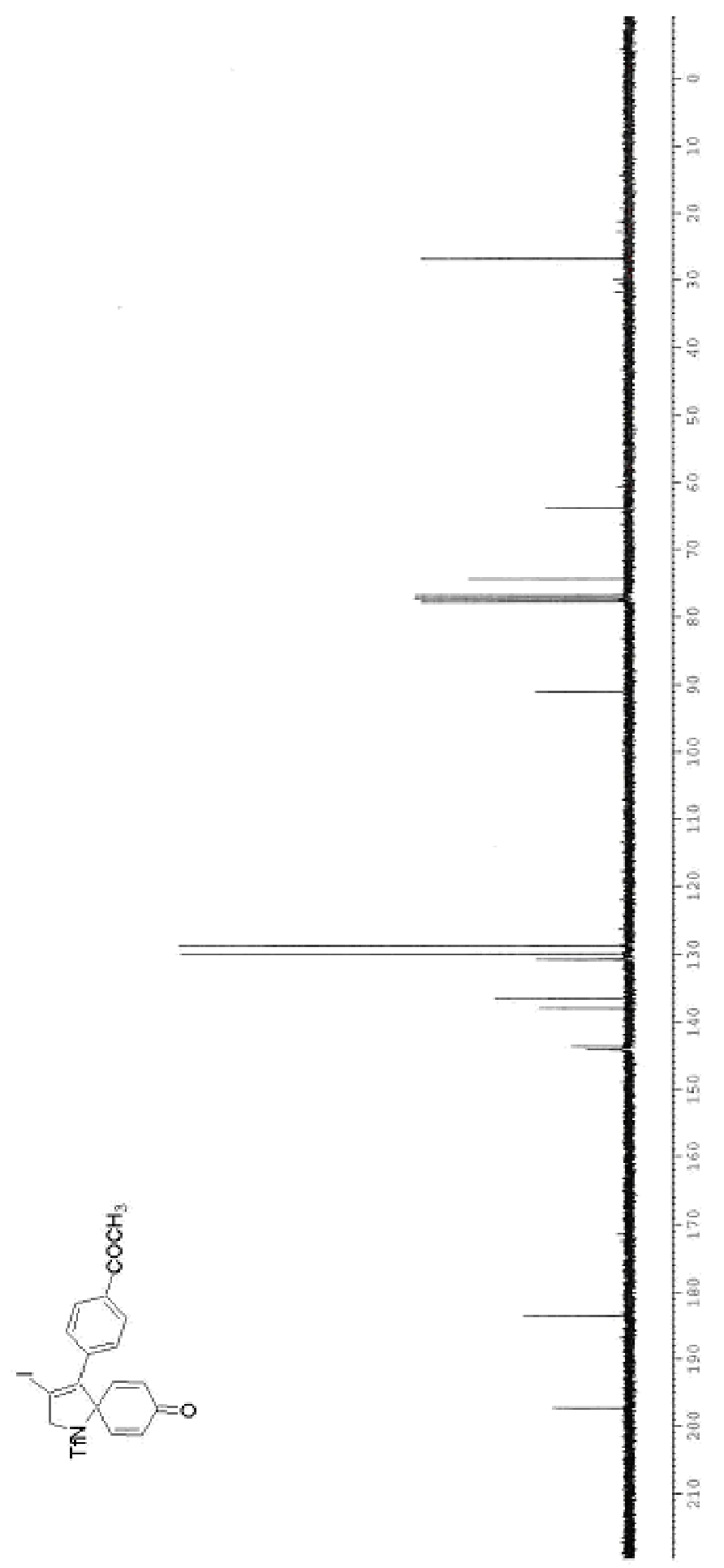



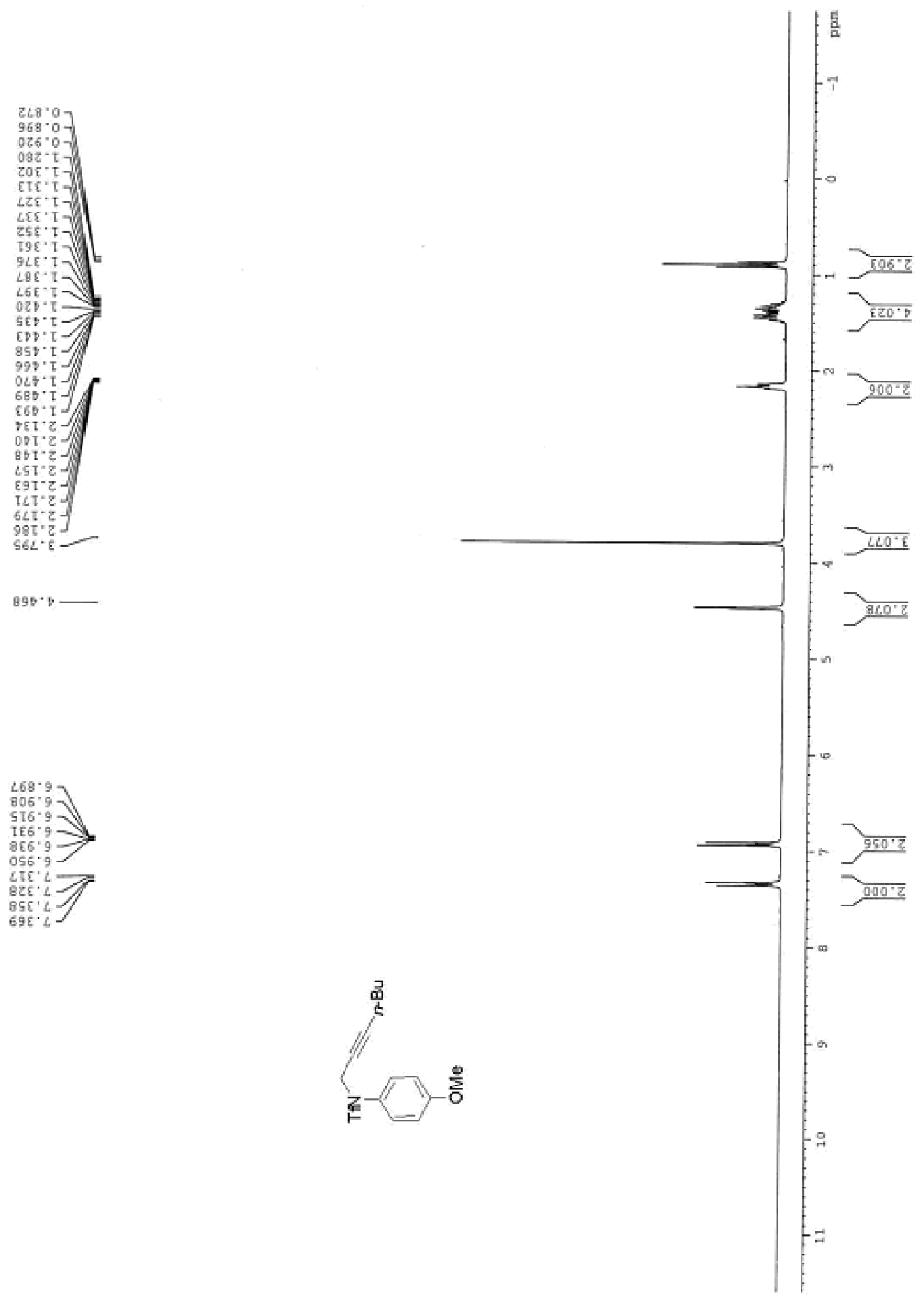

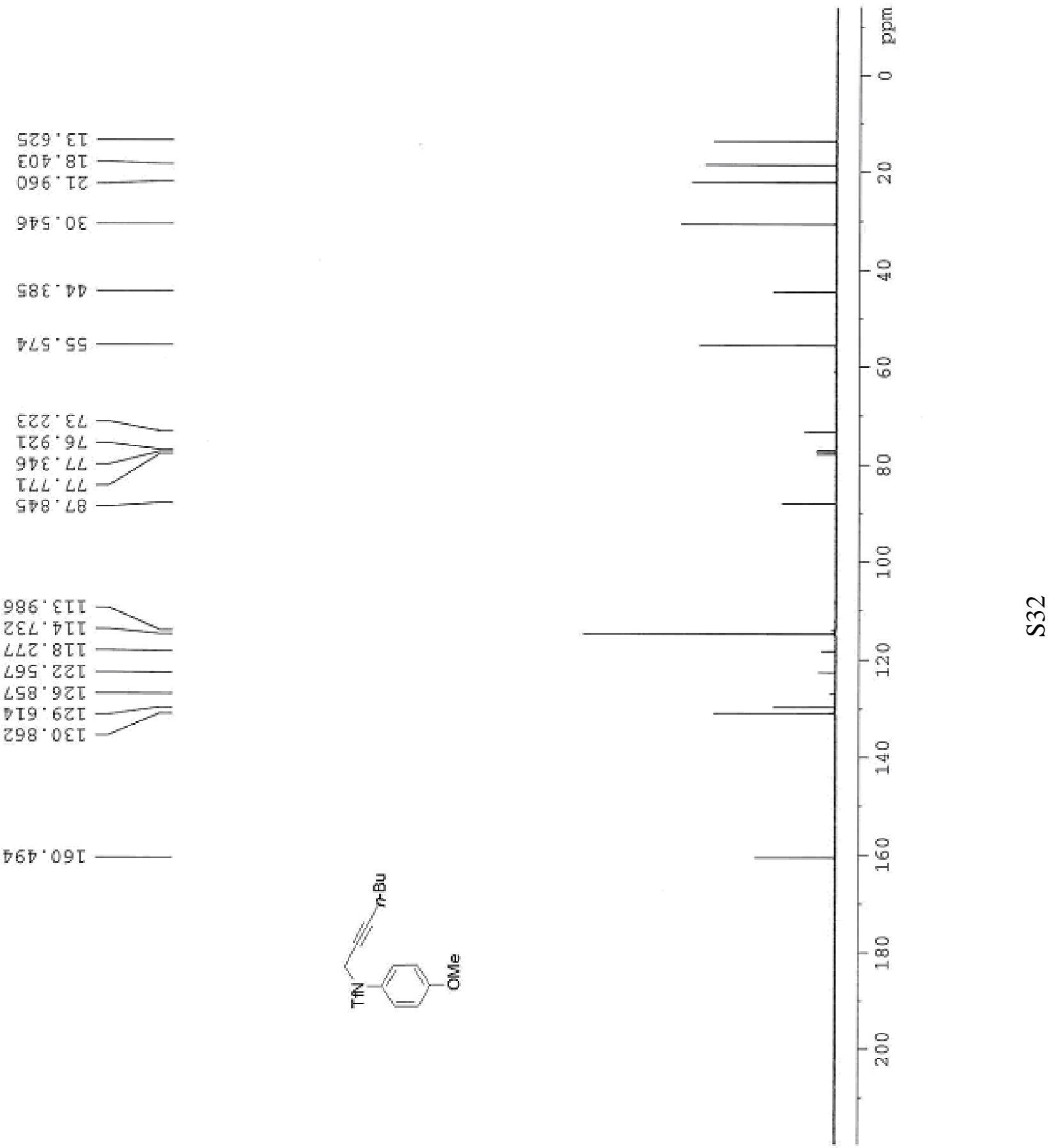

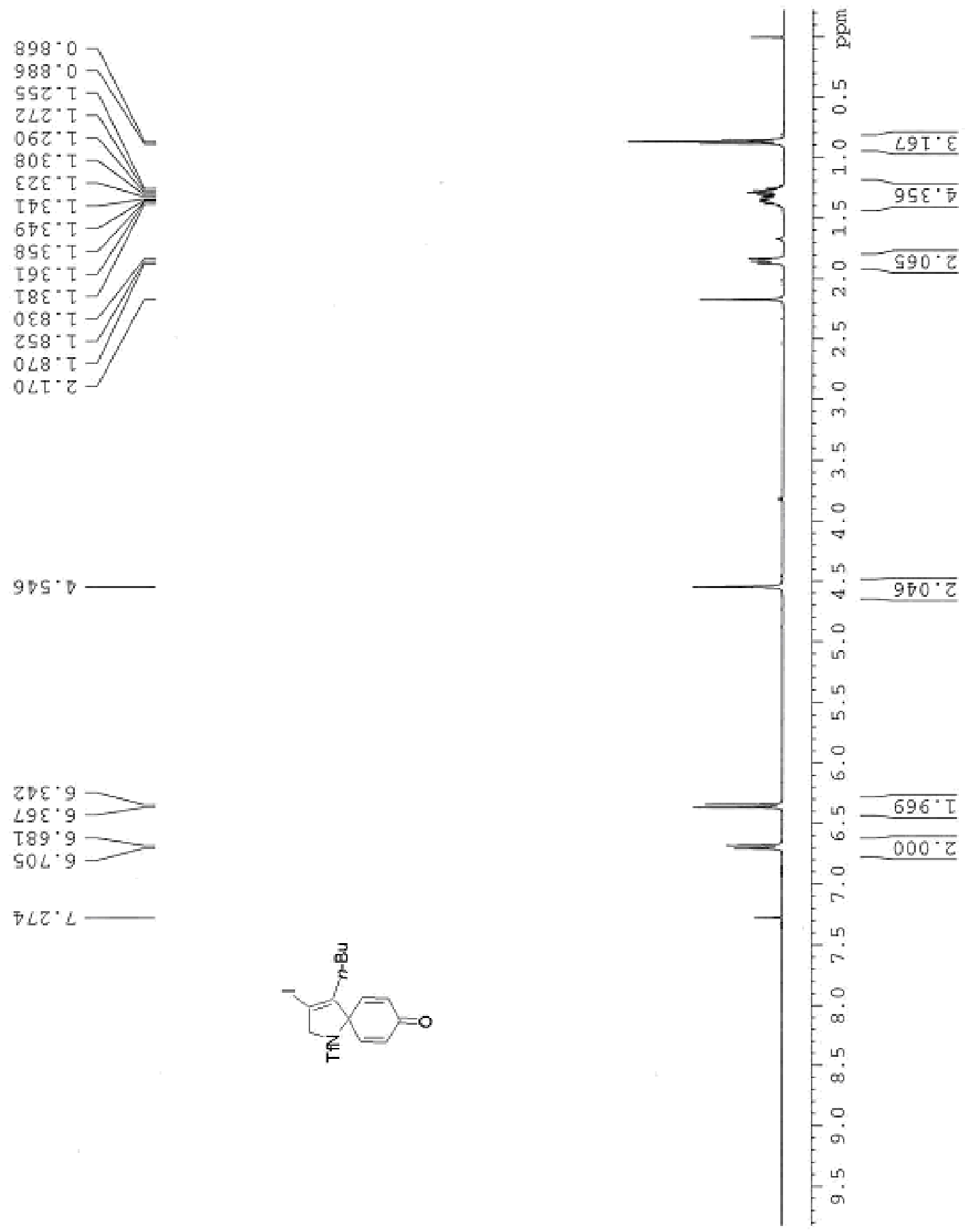

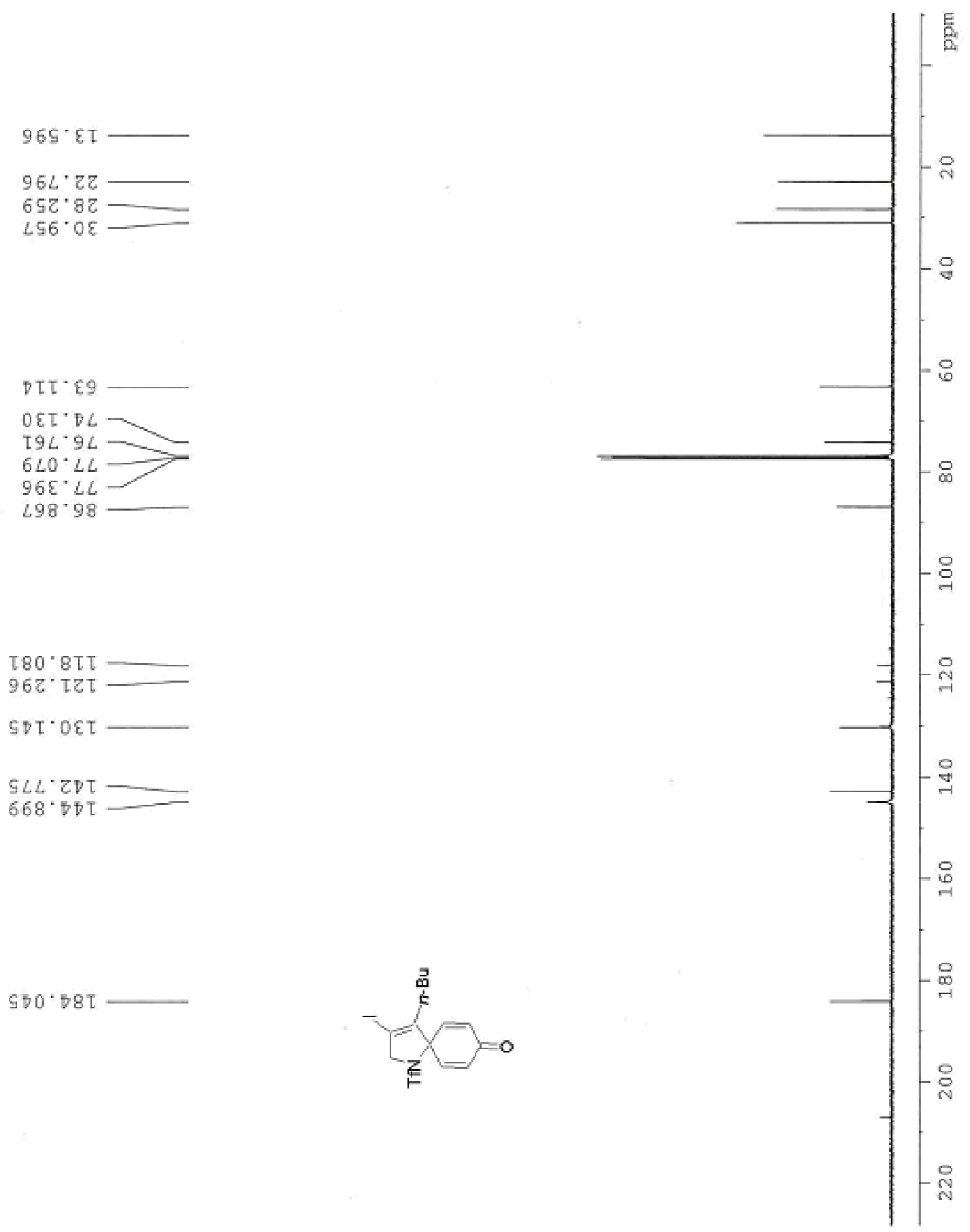

$900.58 \mathrm{~L}$

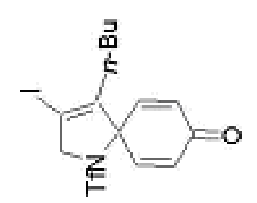




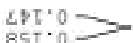

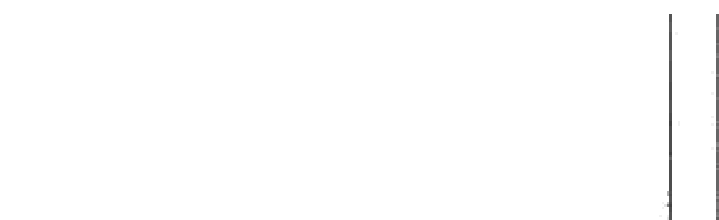

978" :

ELD

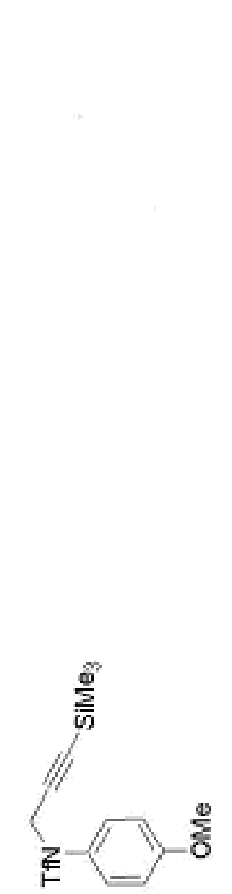

$\operatorname{tin}^{6} \cdot 92=$

${ }^{5 E R}: 4=$

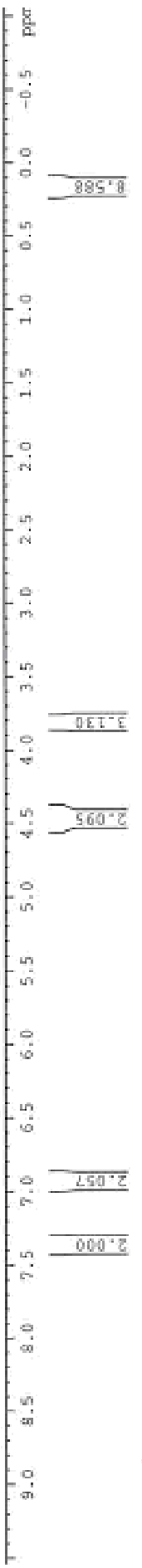




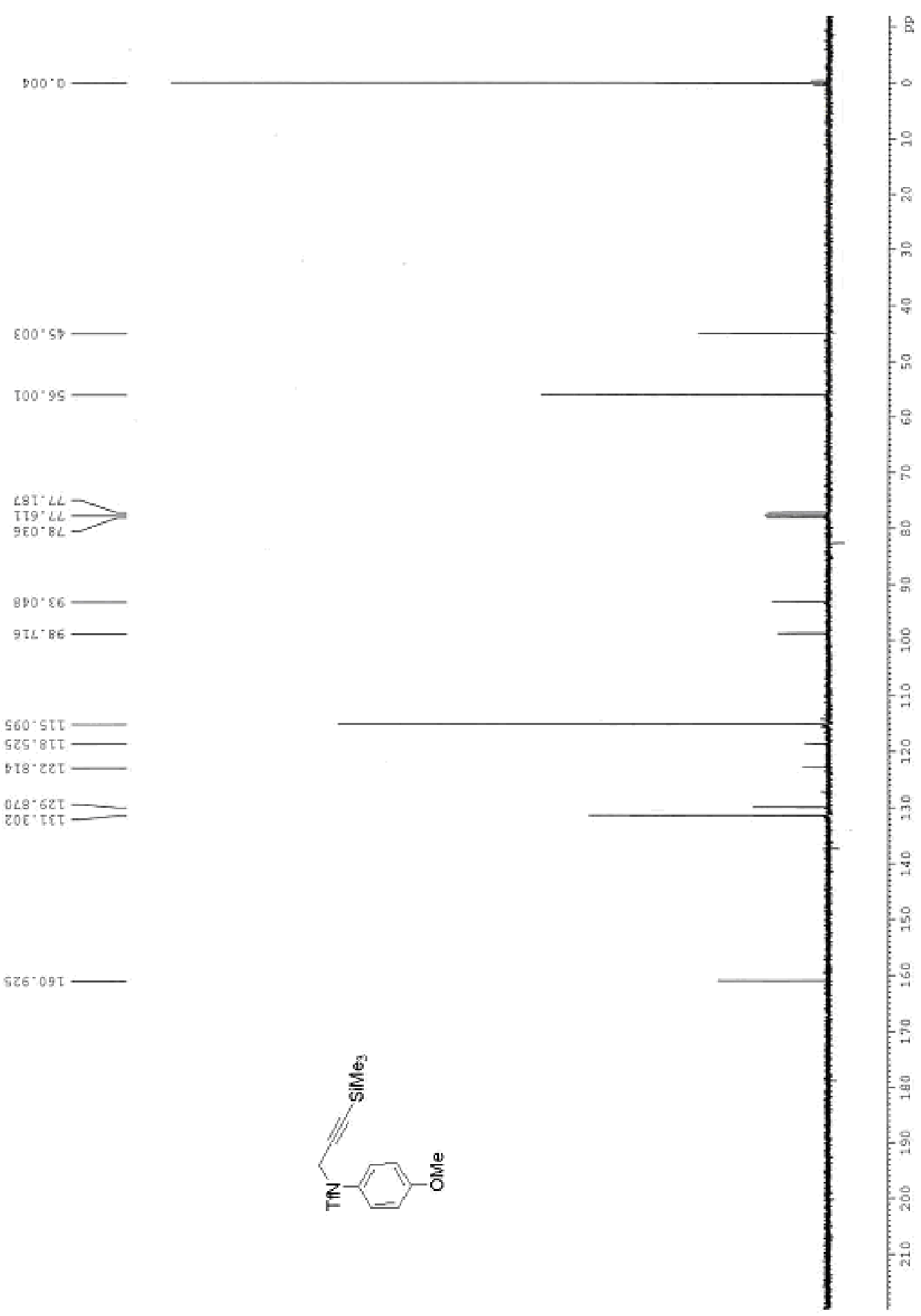

n 


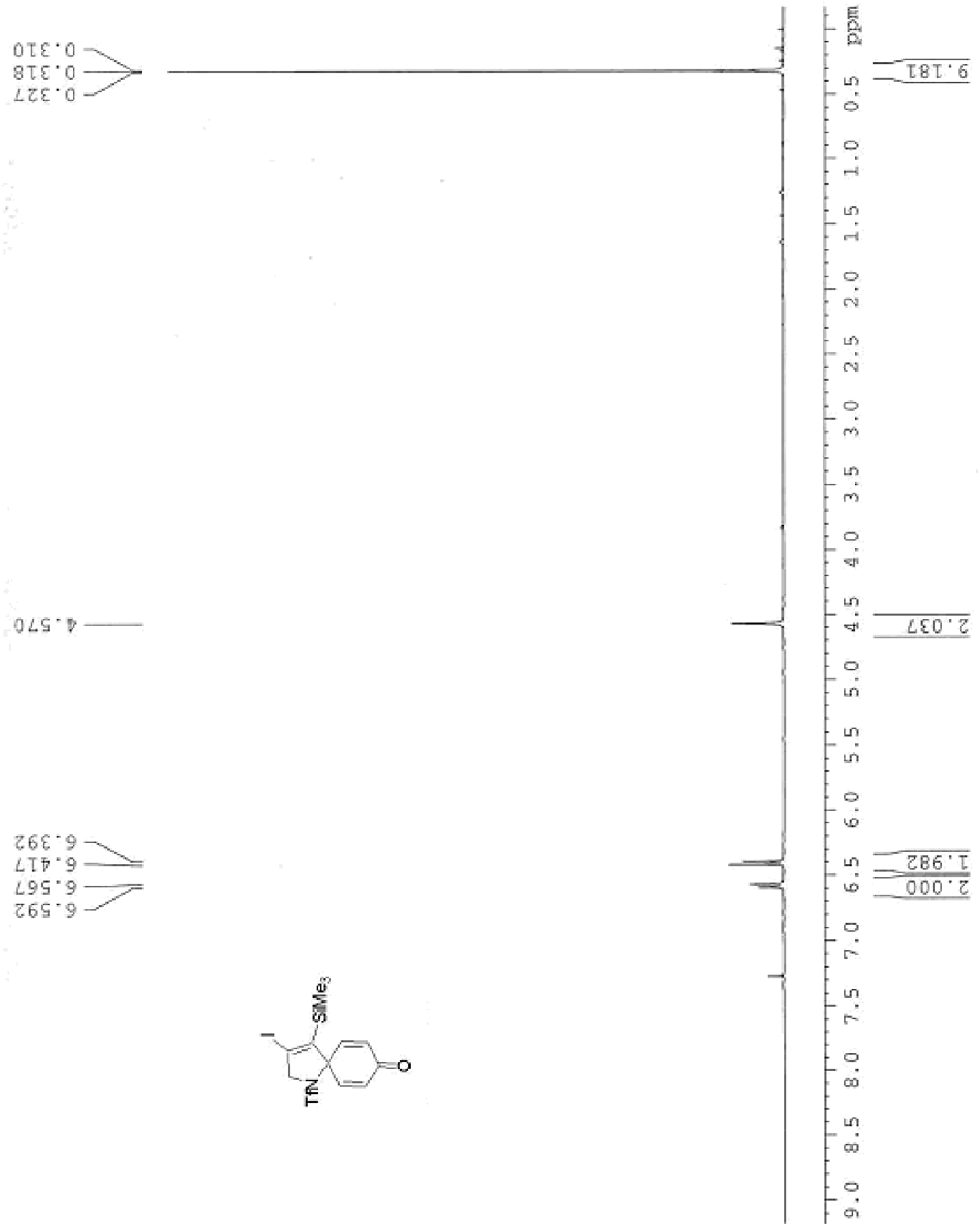



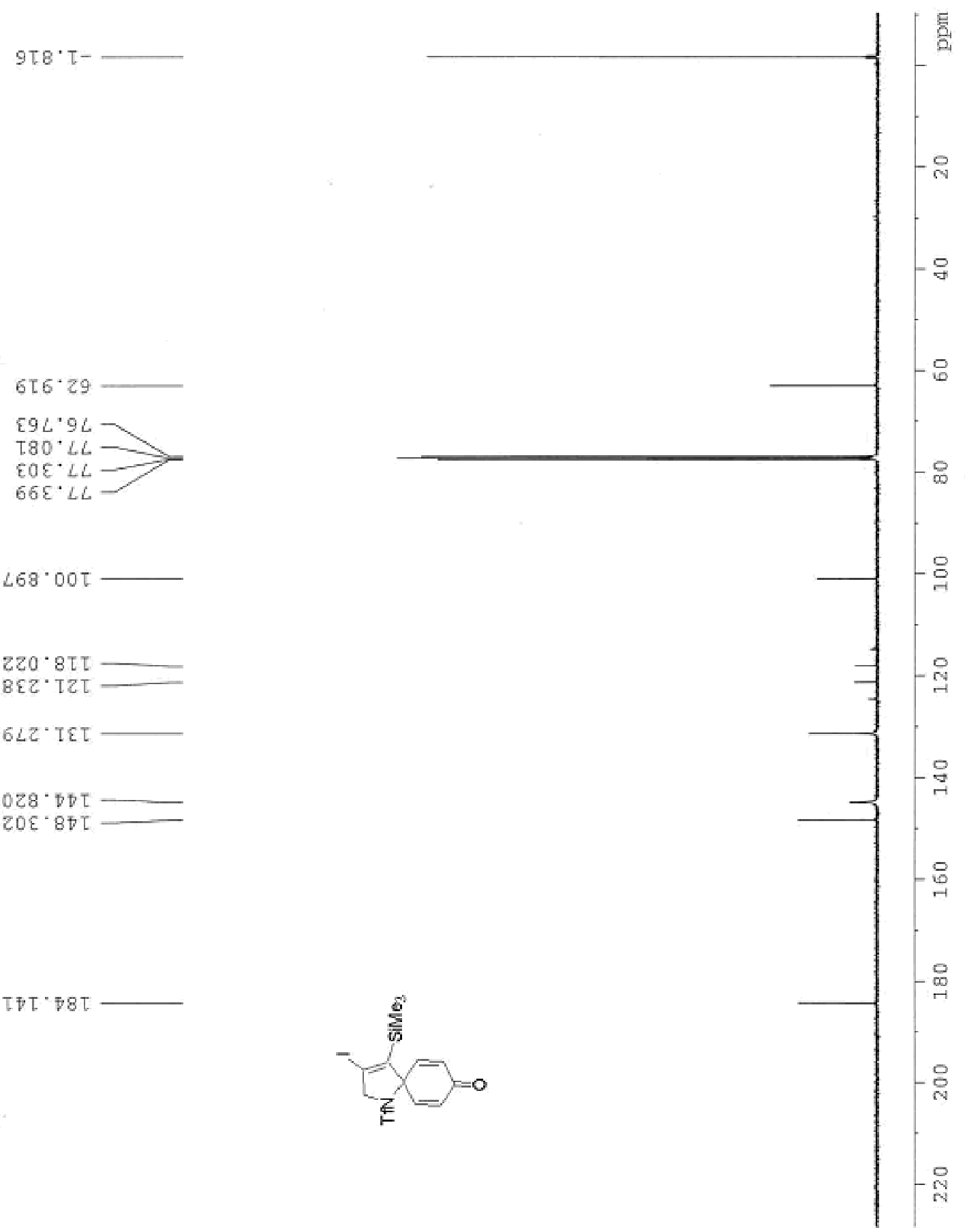


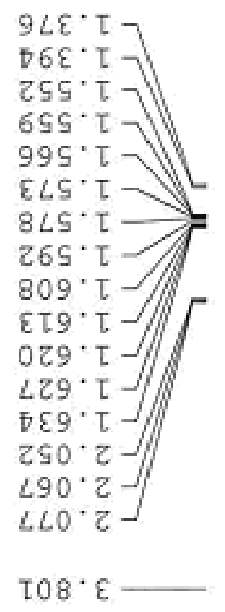

$902 \cdot 5$

$89 \mathrm{z} .5$

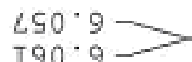

$758.9-$ $806.9 \longrightarrow$ 526.9 TZE $L D$

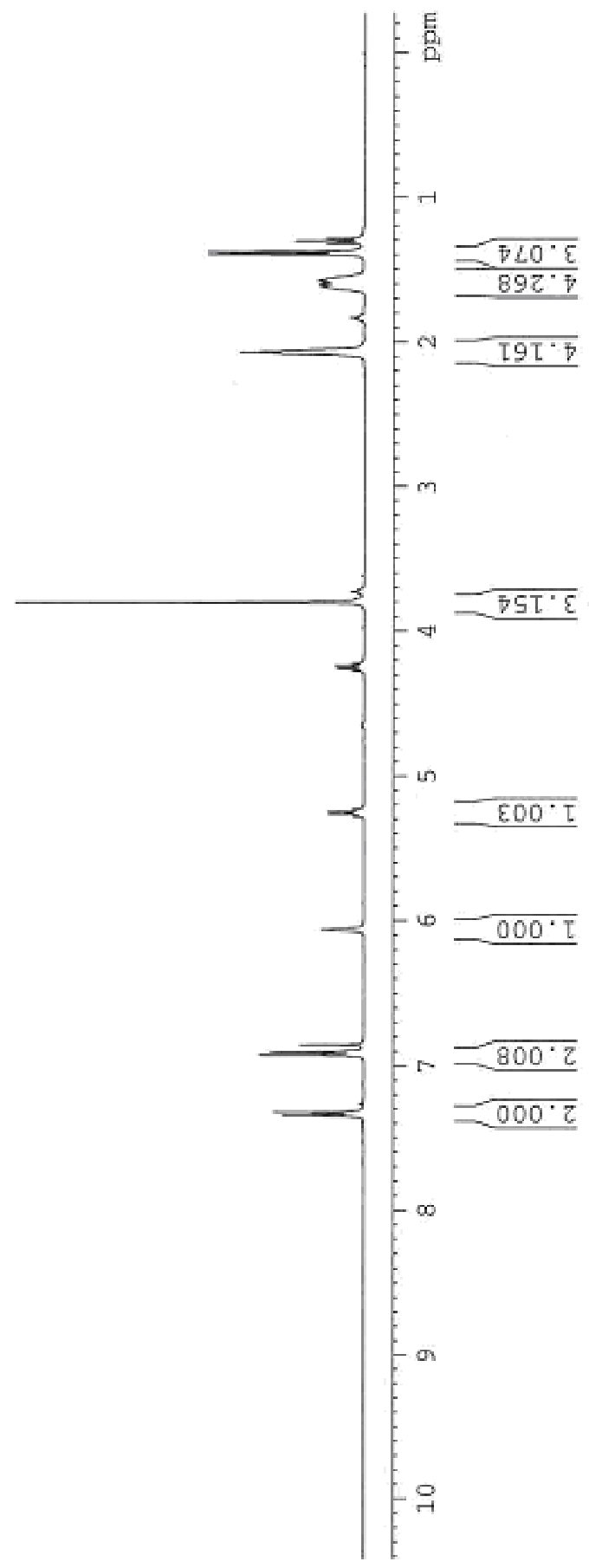



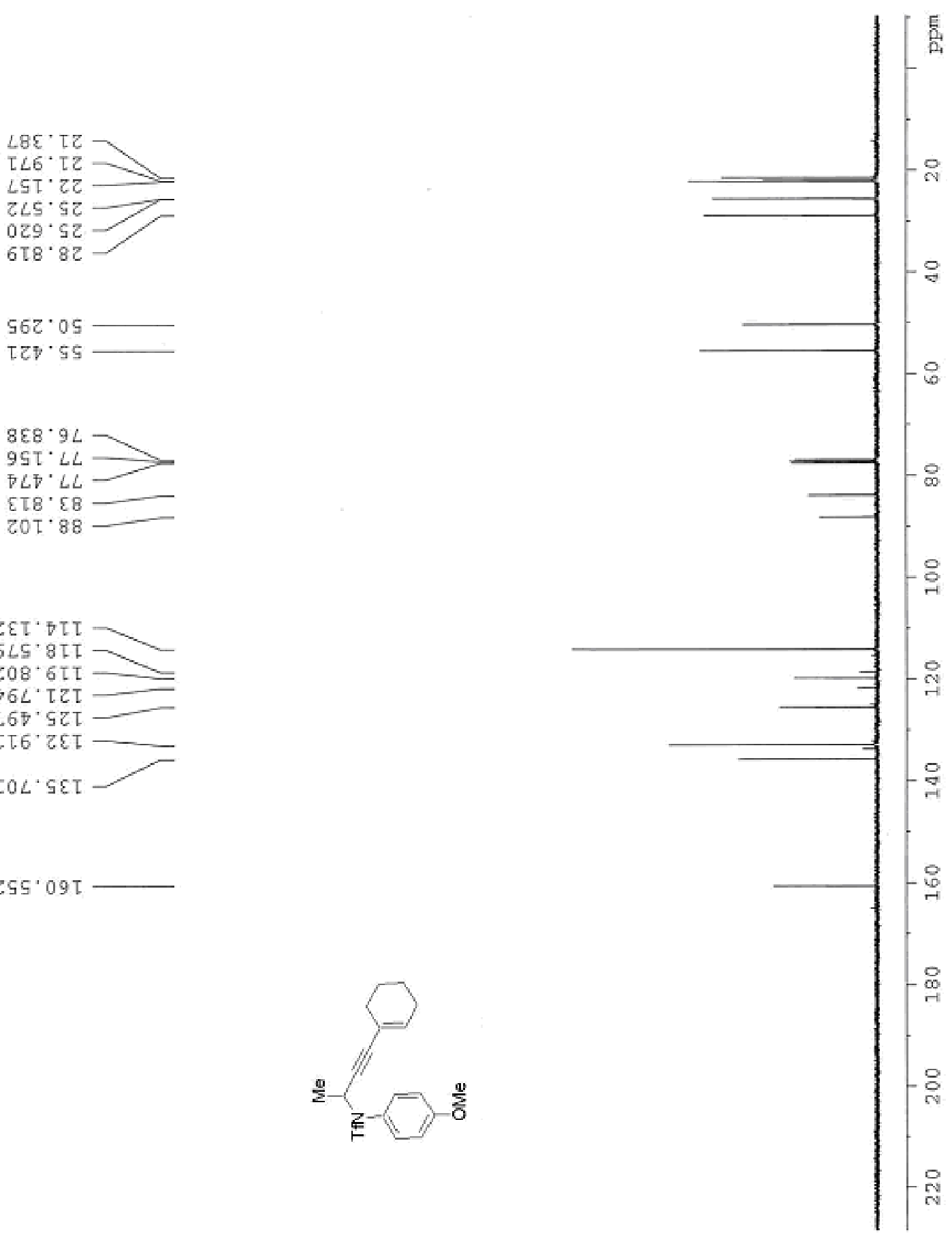

ษ

ZSS.09T

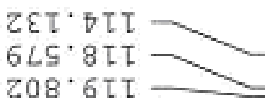

$764^{\circ}$ T ZT

$\angle 67^{\circ} \mathrm{GCT}$

T.T. $6 \varepsilon I \longrightarrow$

IOL'SEI

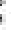

$56 Z^{\circ} 05$

$8 E 8 \cdot 9 L$

99 I. LL

ETB' $\varepsilon 8$
COT' 88

ZSS.09T

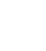

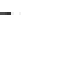



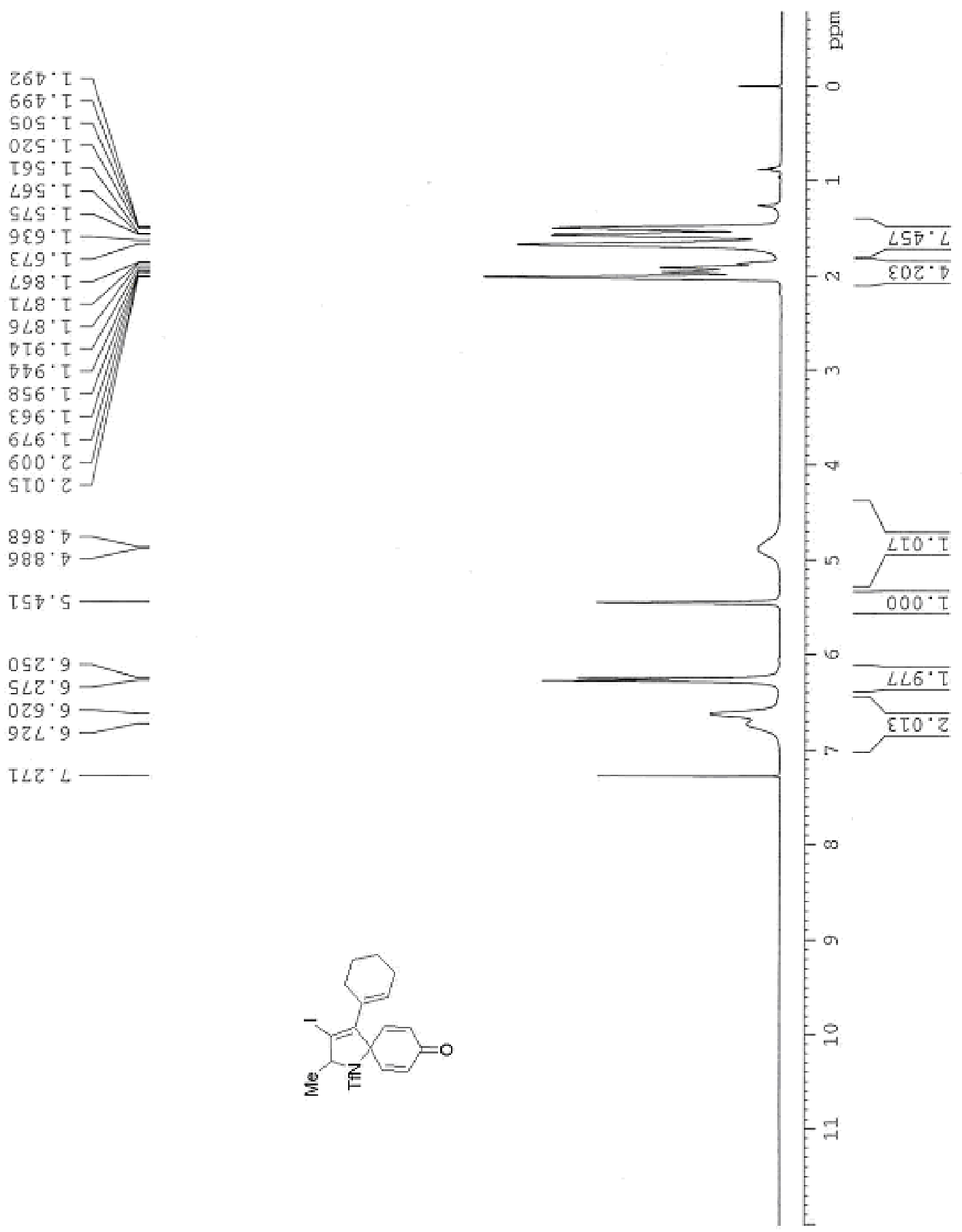

F 

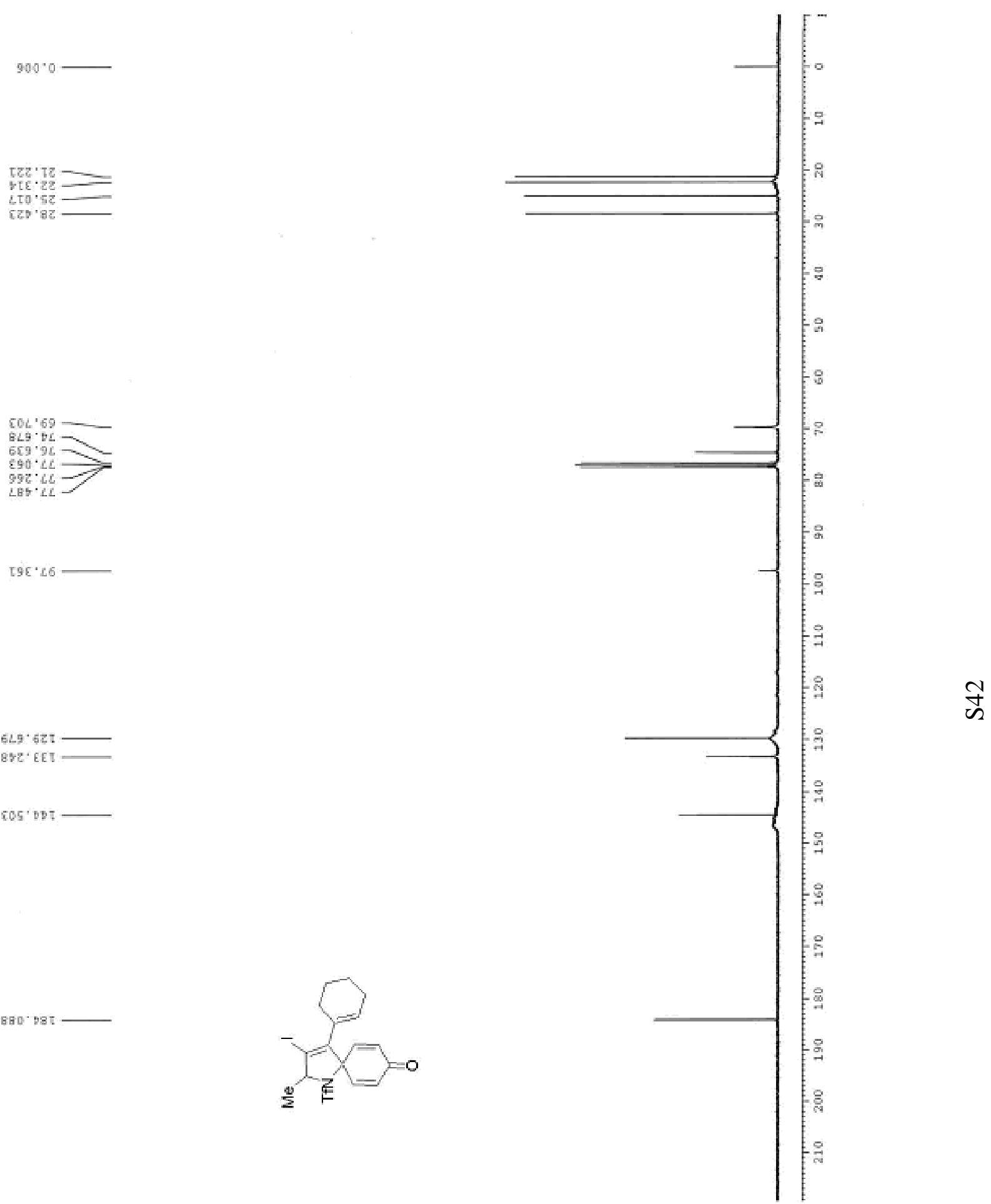

$649.62 \pi$

Tez'TZ=

L50.5z

320.

COL' 69

EL9'b

$690^{\circ} \cdot \mathrm{LL} \longrightarrow$

$465 \cdot 64-$

I96'LS -

B): EET -

CO5 $\mathrm{DDT}$

ษับ

1860.087

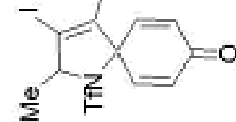


OTB. T

$T S L^{*} \varepsilon$

$9 \tau 9^{\circ}:-$

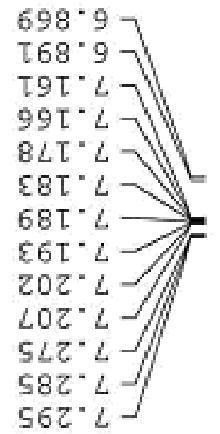

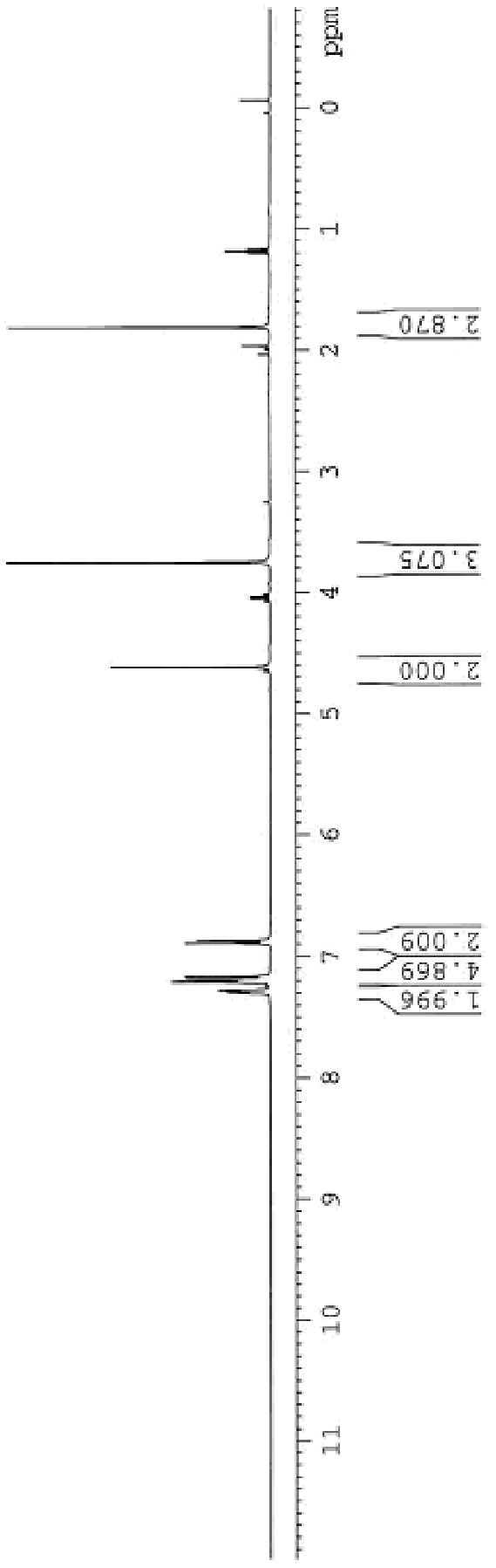



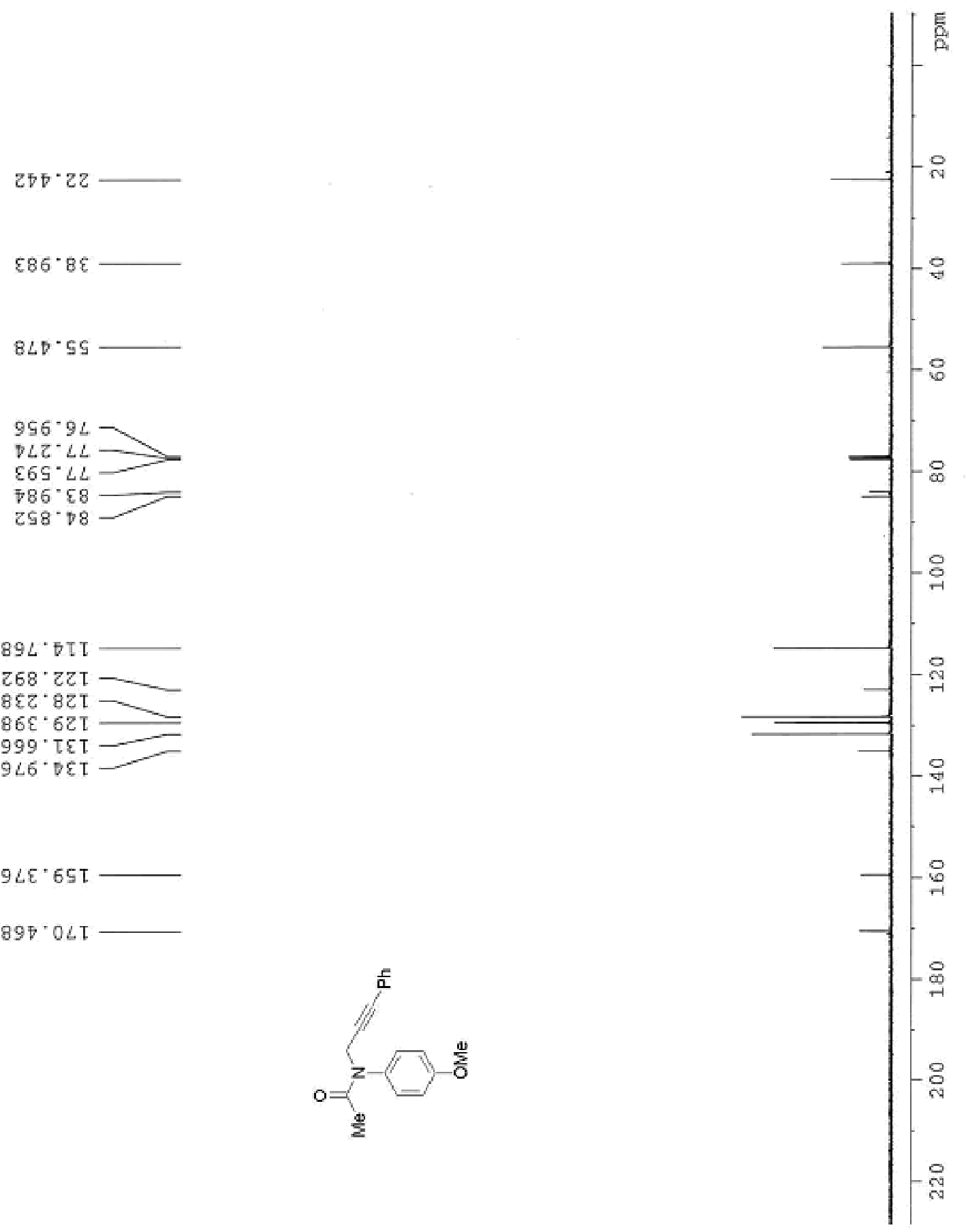

\& 

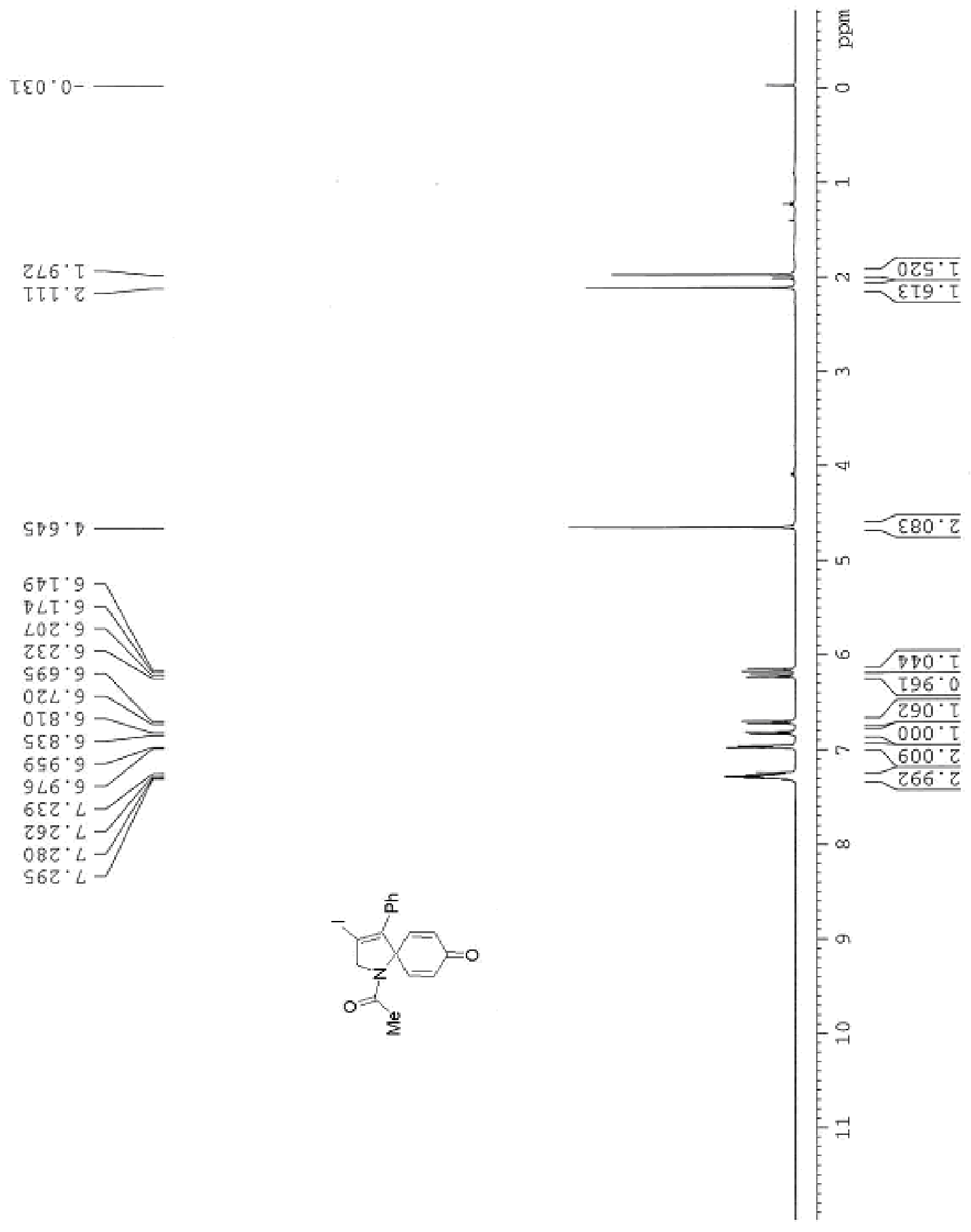
OTL TZ

$664.72-=$

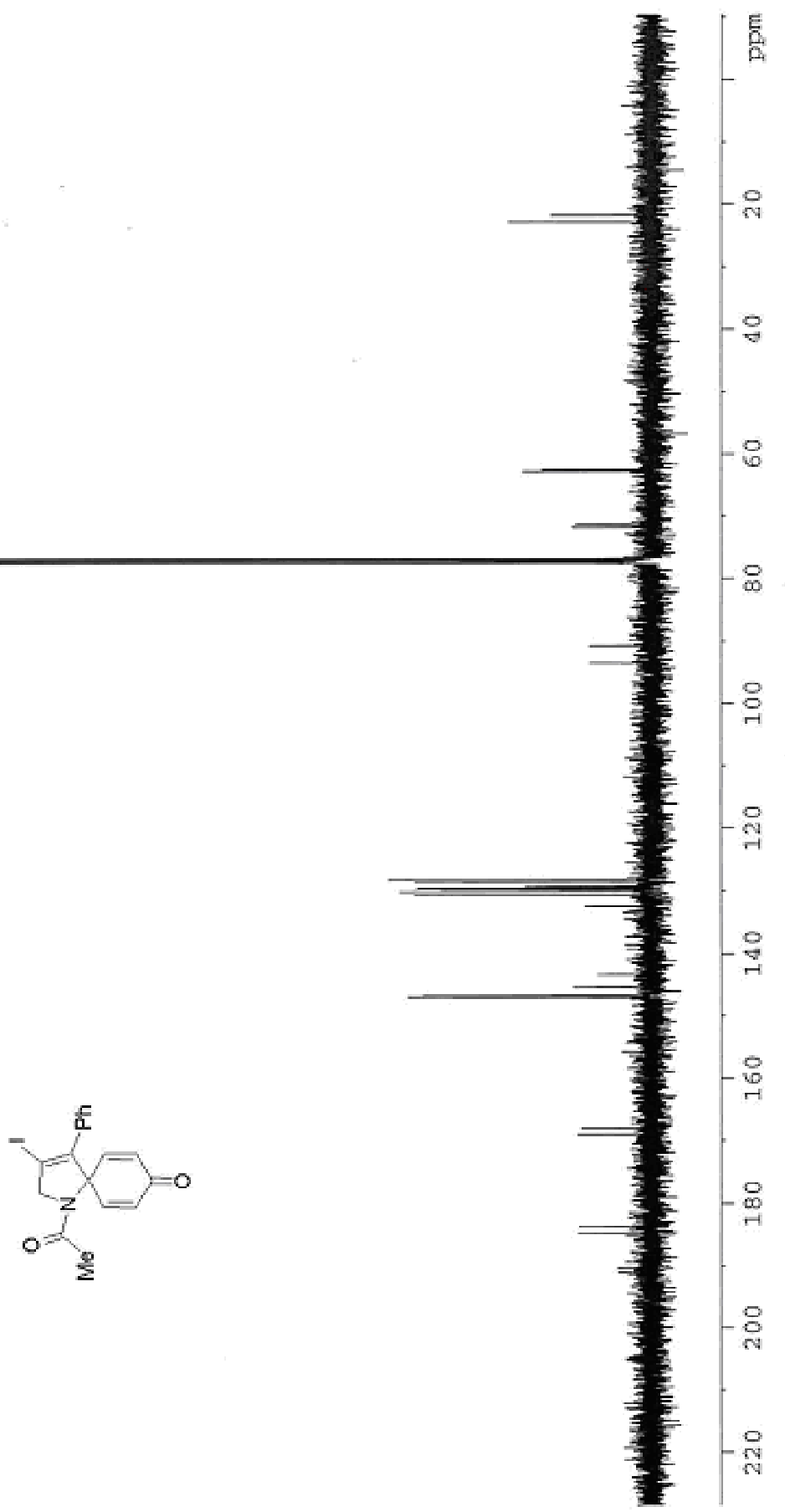

ป 
6LA'T-

$296^{\circ} \mathrm{C}$

09913
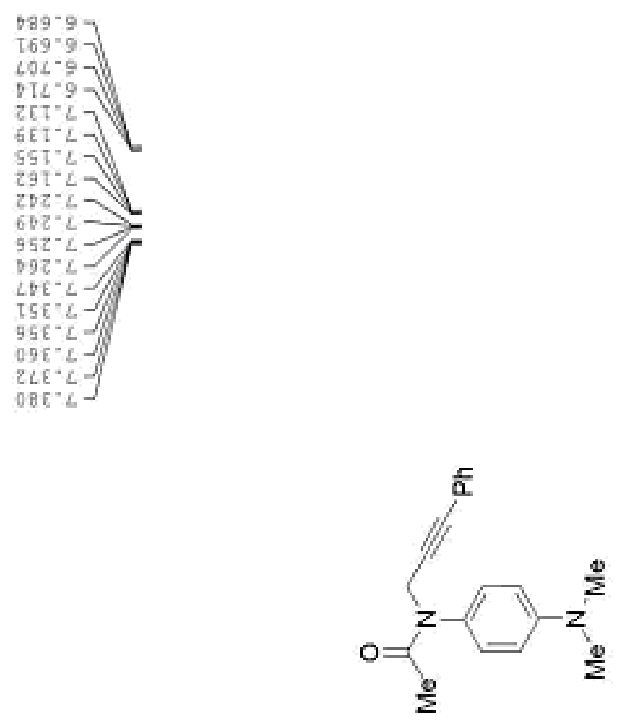

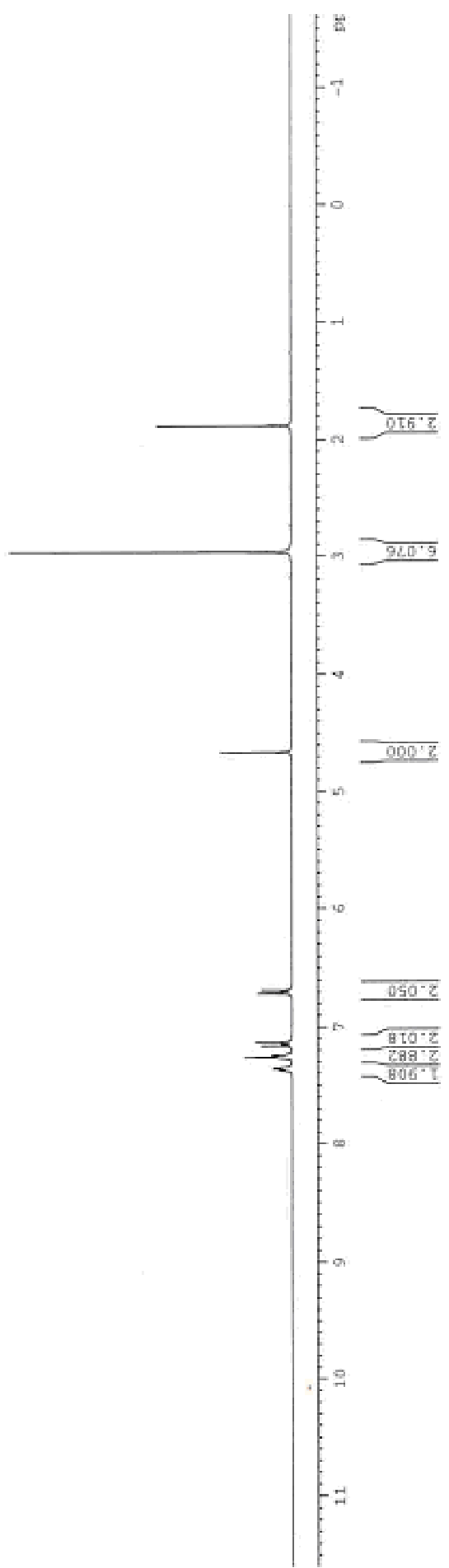




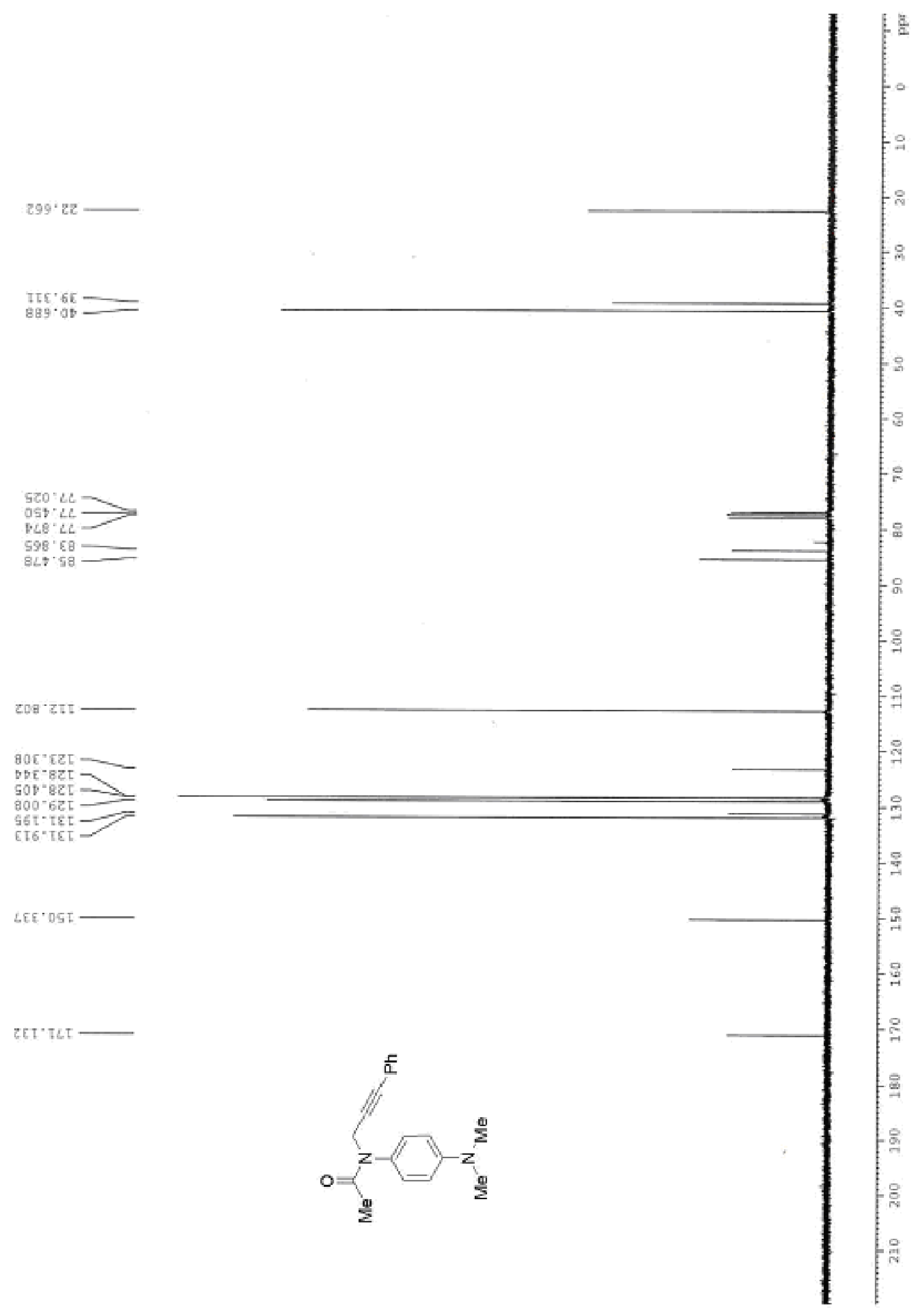



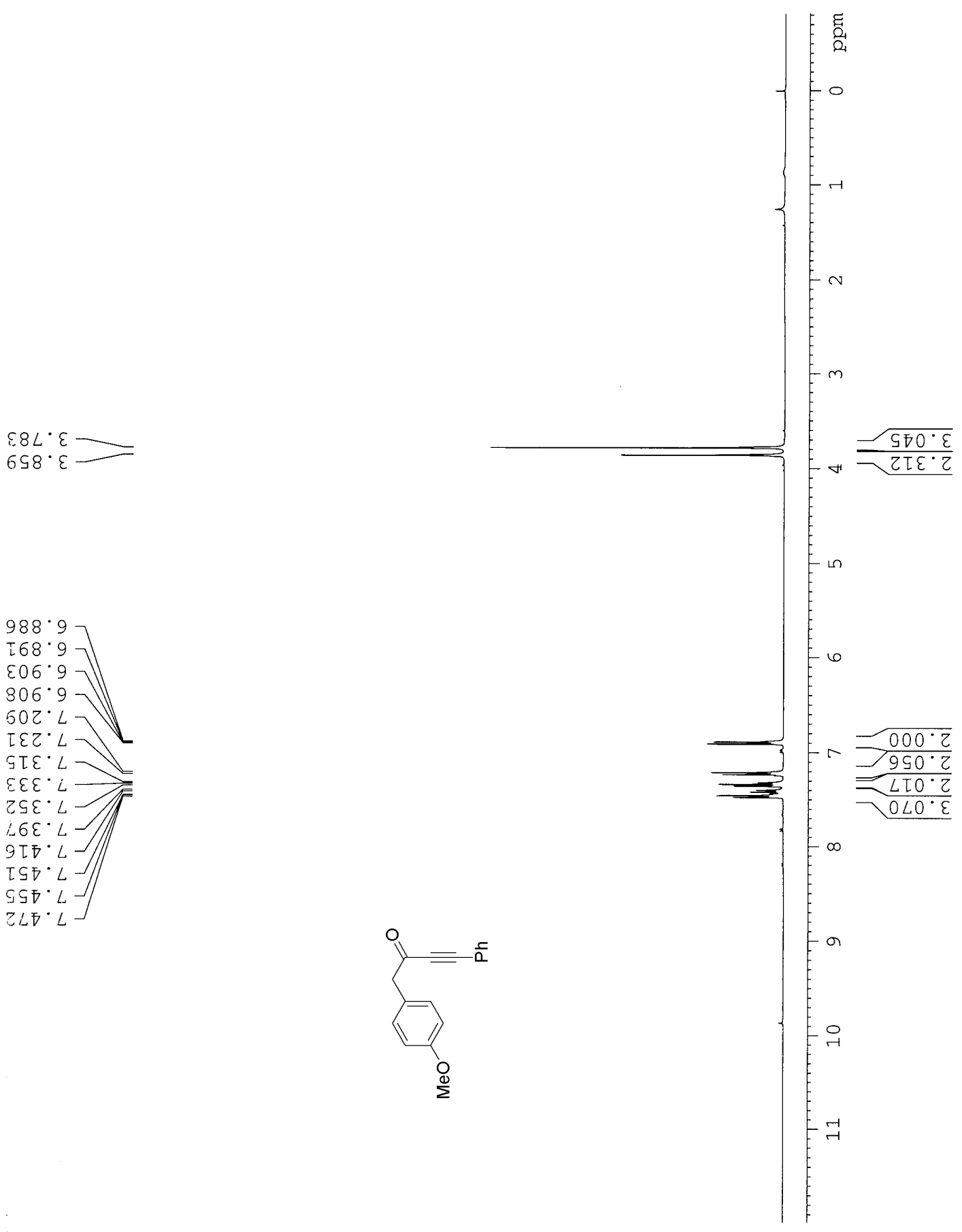

守

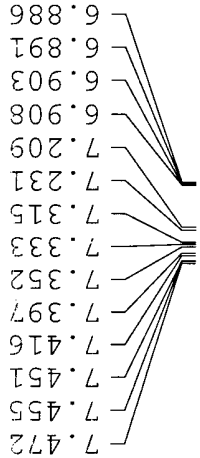



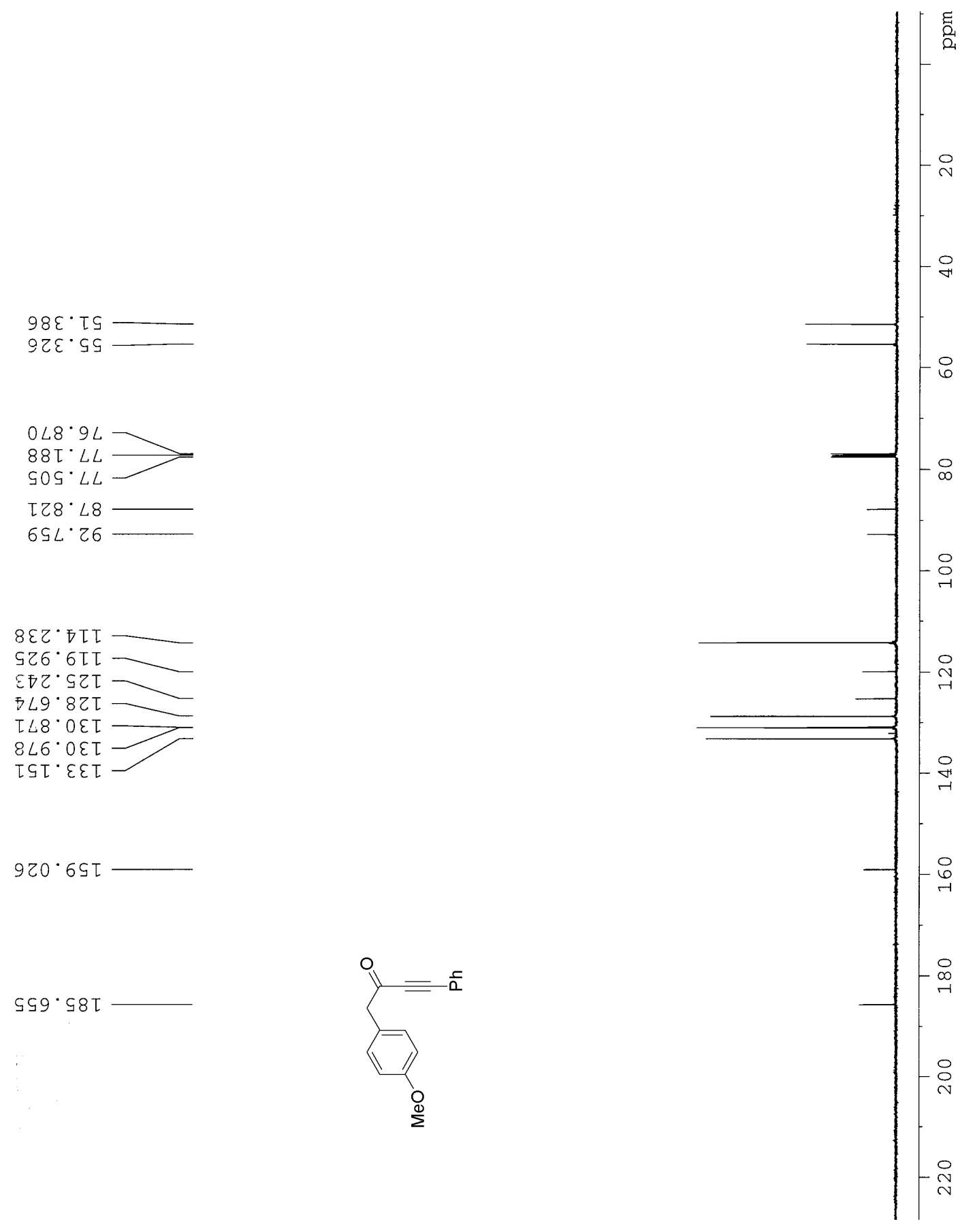

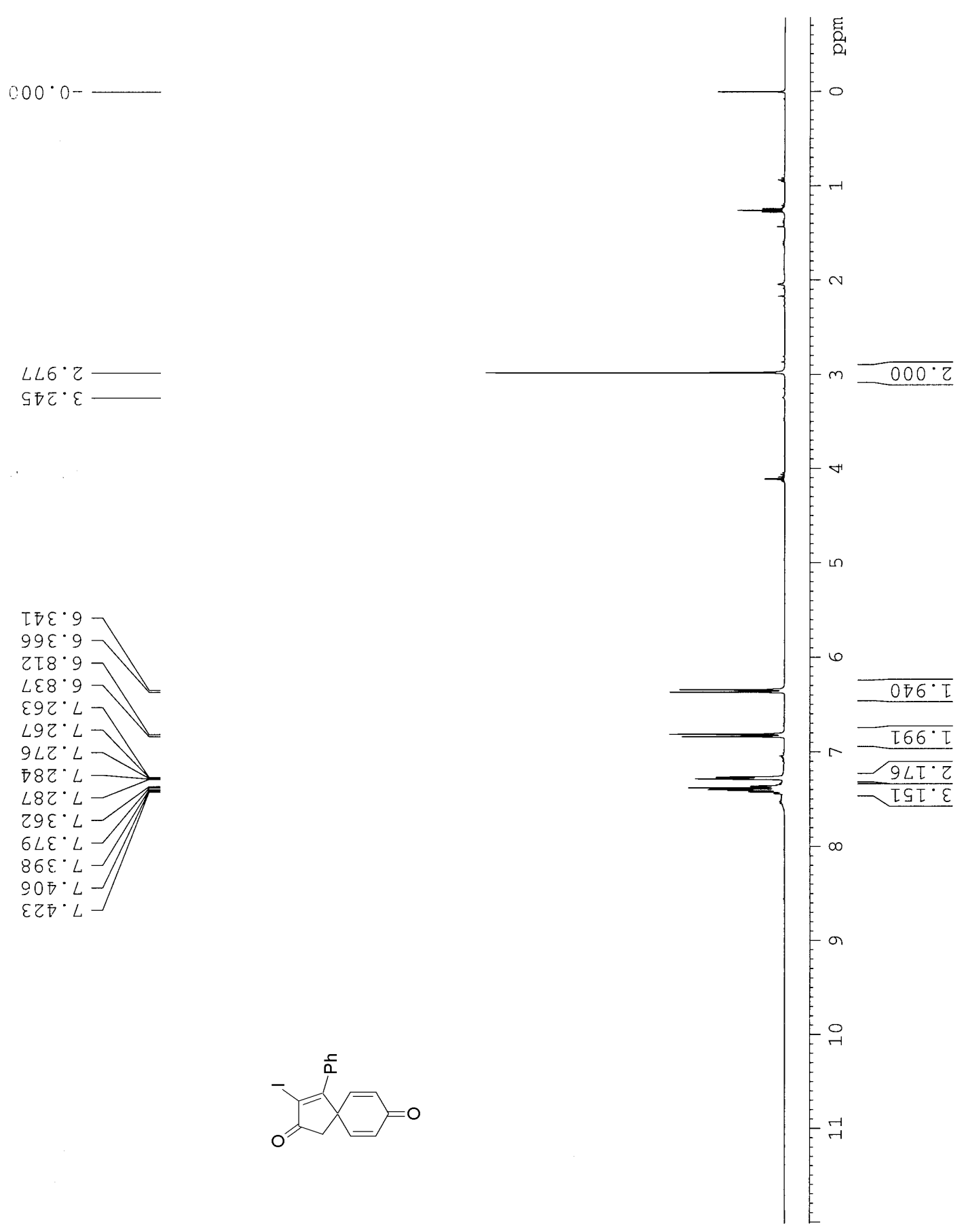


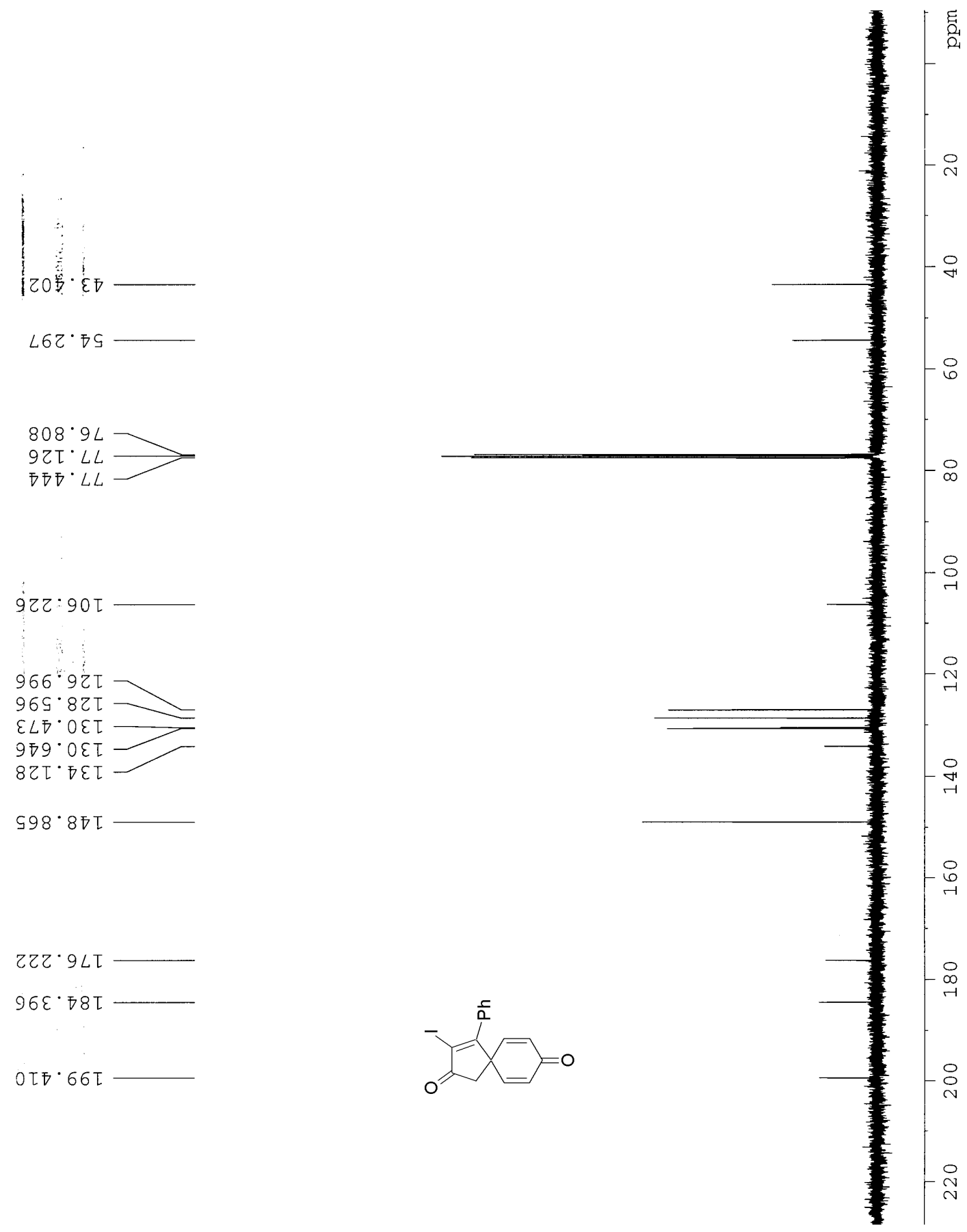



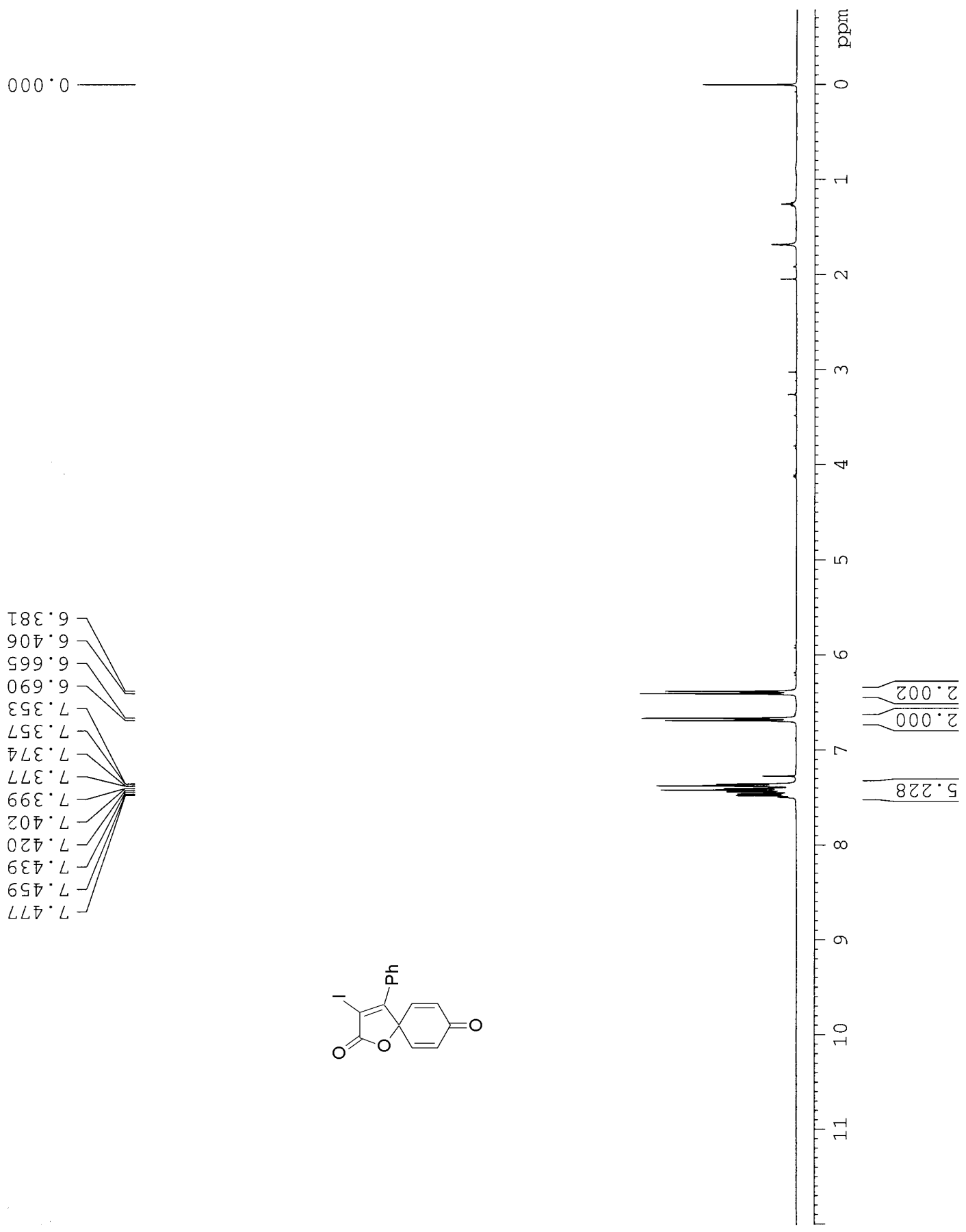


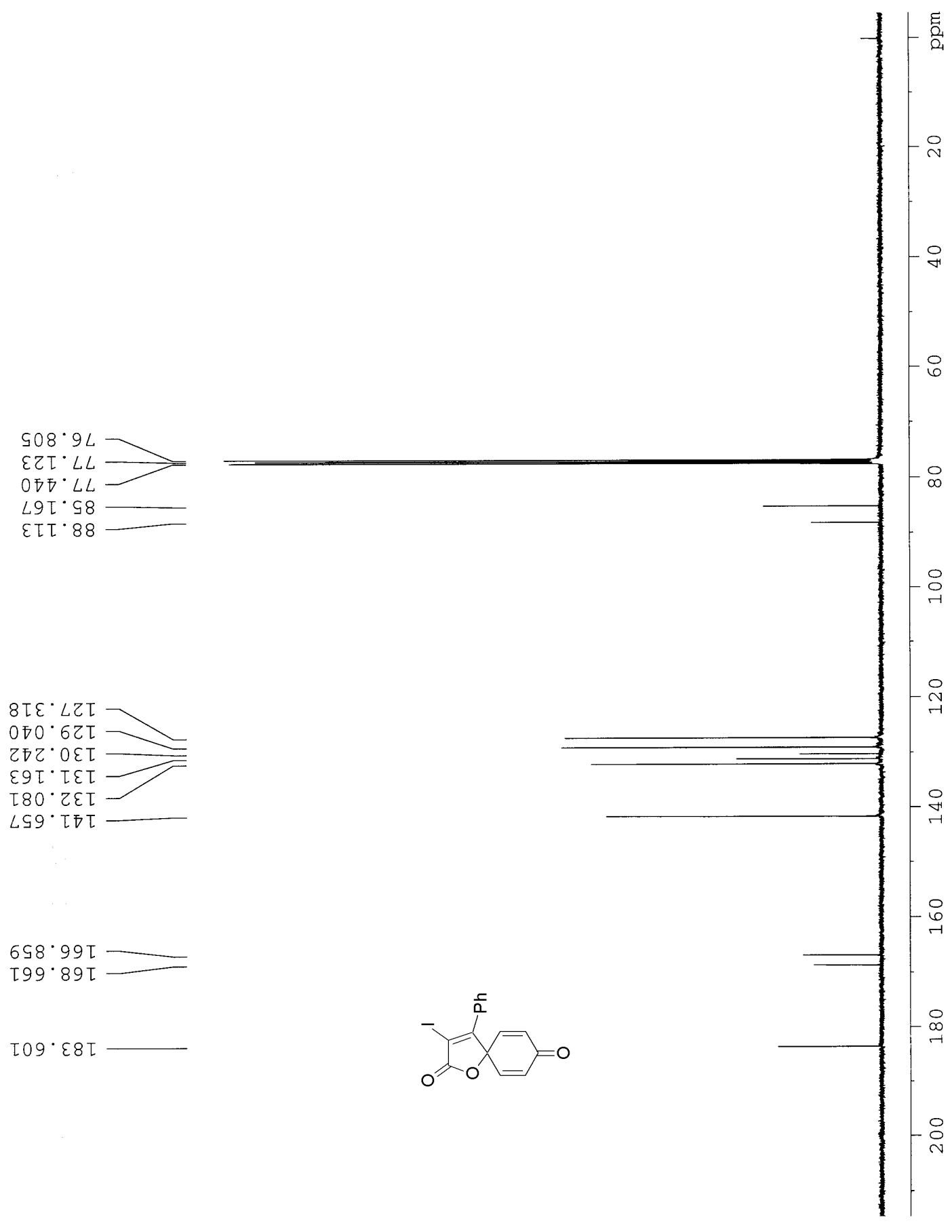


$796^{\circ} \mathrm{T}$

$050^{\circ} \mathrm{Z}$

$\bar{\nabla} \angle 8^{\circ} Z-$

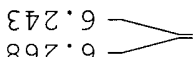

$892 \cdot 9=$

૬ع $6^{\circ} 9$ $696 \cdot 9 \longrightarrow$

$0 L \varepsilon^{\circ} L$

OZஏ.

9乙7・L

乙ย乙 8

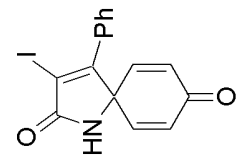

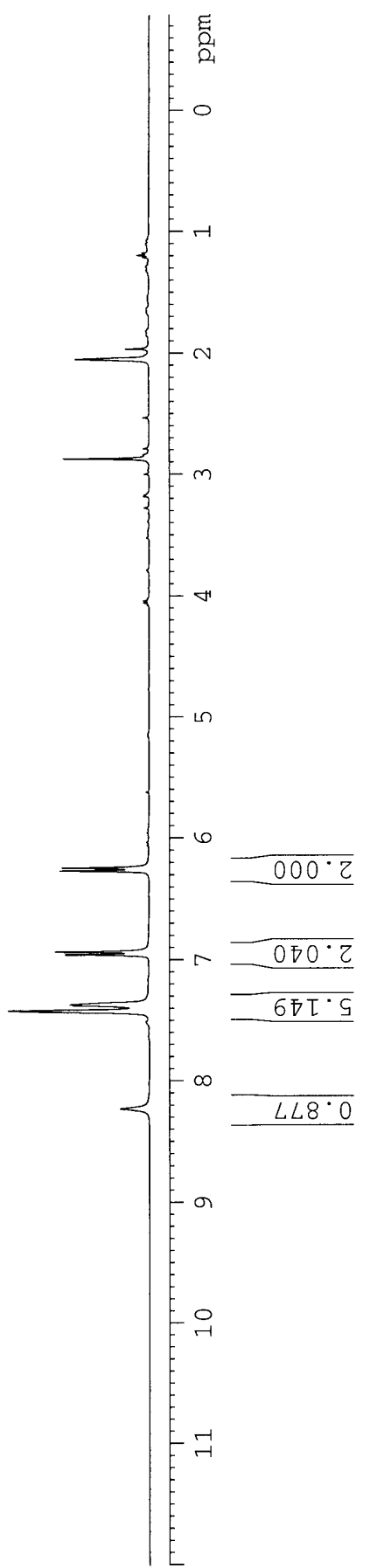


Z2L.99

$\varepsilon 66^{\circ} 86$

$890 \cdot 82 \tau$

$0 Z 0^{\circ} 8 \mathrm{TL}$

$089^{\circ} 62 \mathrm{~T}$

2Z9.0हT

乙68. $2 \varepsilon \tau$

$8 Z L \cdot 97 T$

$869^{\circ} 09 T$

$\varepsilon 89^{\circ} 89 \mathrm{~T}$

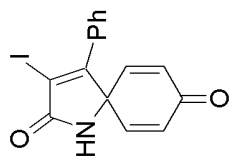

$68 L \cdot \varepsilon 8 T-$

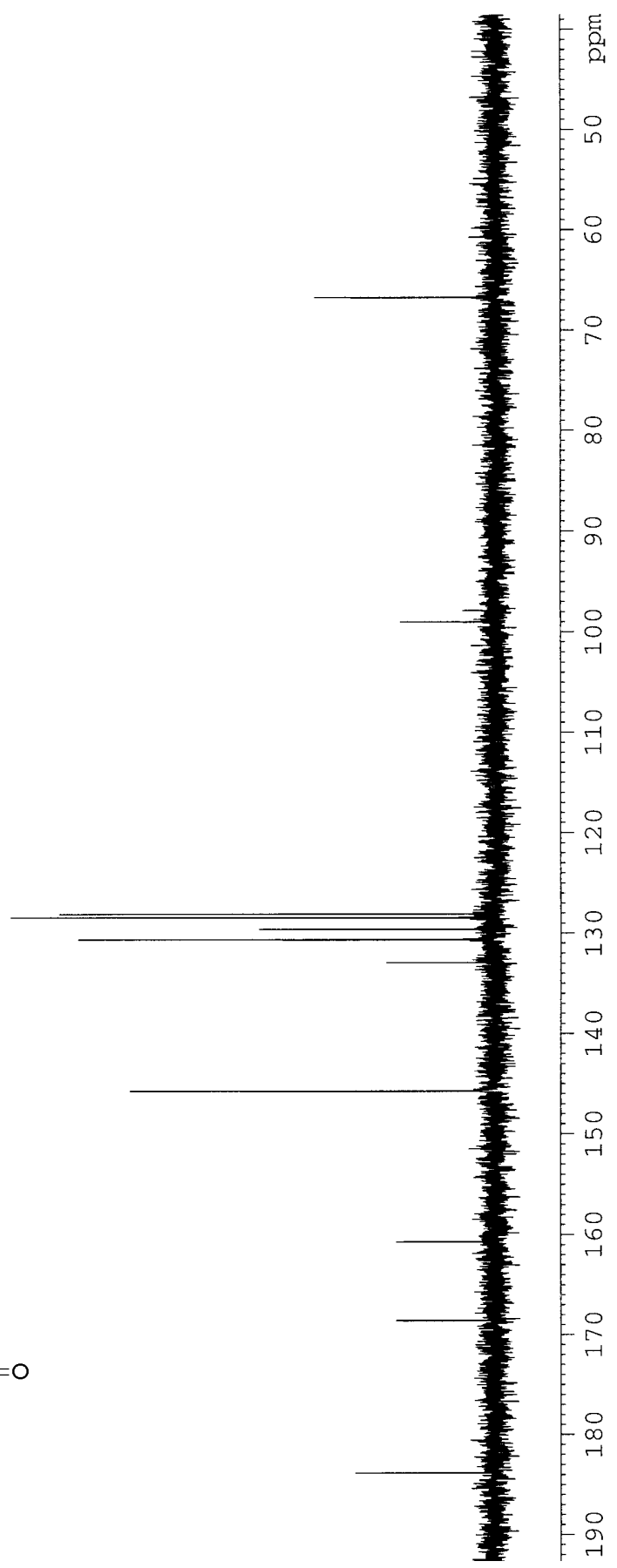




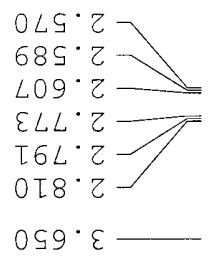

$6 L L \cdot 9-$ $008 \cdot 9-$

IOI' $L]$

Z2I $L]$

$Z L I \cdot L\rceil$

$6 \angle T \cdot L$

$8 T^{\circ} L \backslash$

$06 I^{\prime} L$

$86 I^{\circ} L$ SOZ. $L-$ $602: L-$ бच $\varepsilon^{\circ} L$

$\subseteq \varepsilon \cdot L J$

ट9ع $L-$

$\angle 9 \varepsilon \cdot L]$

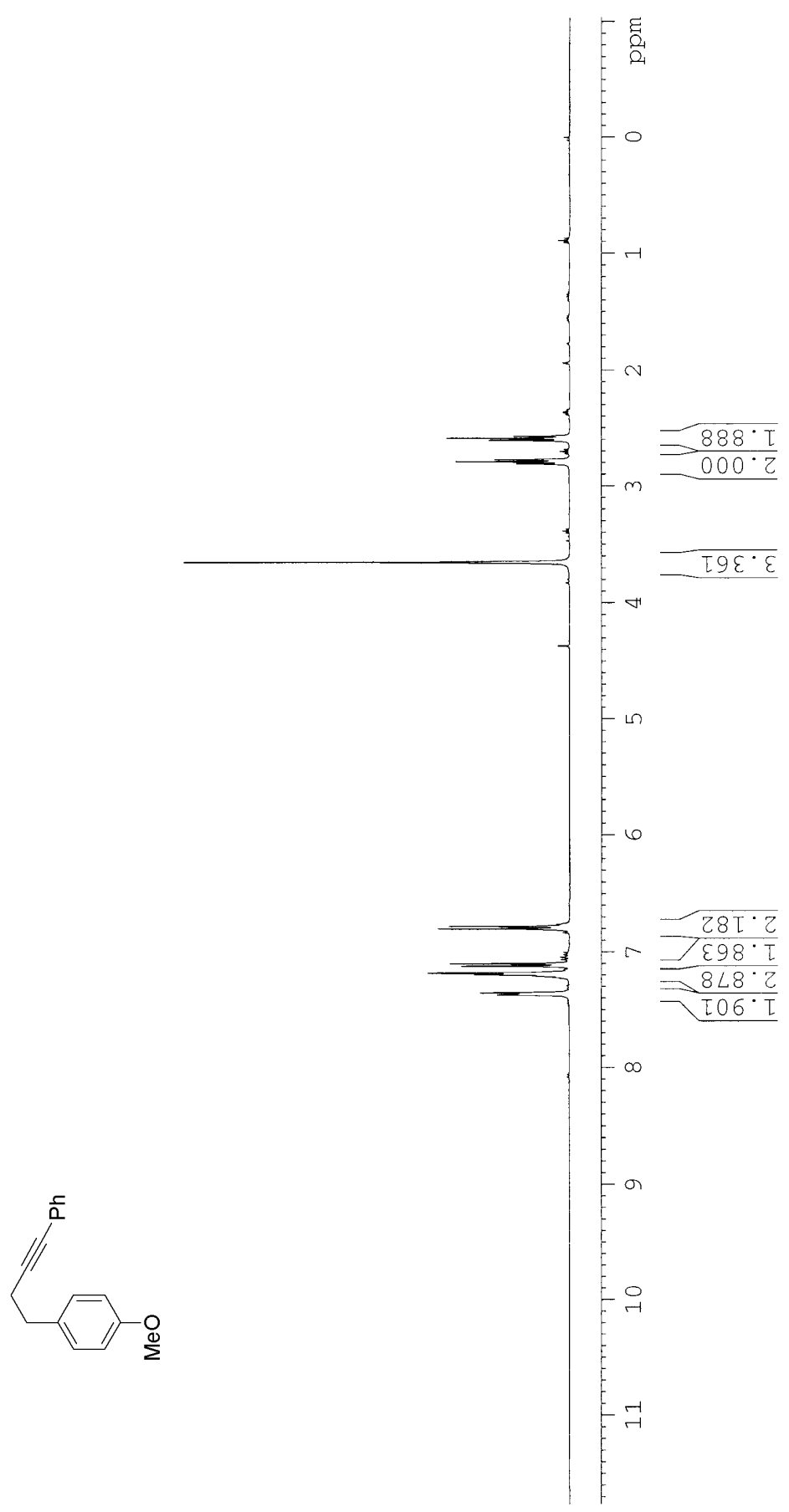



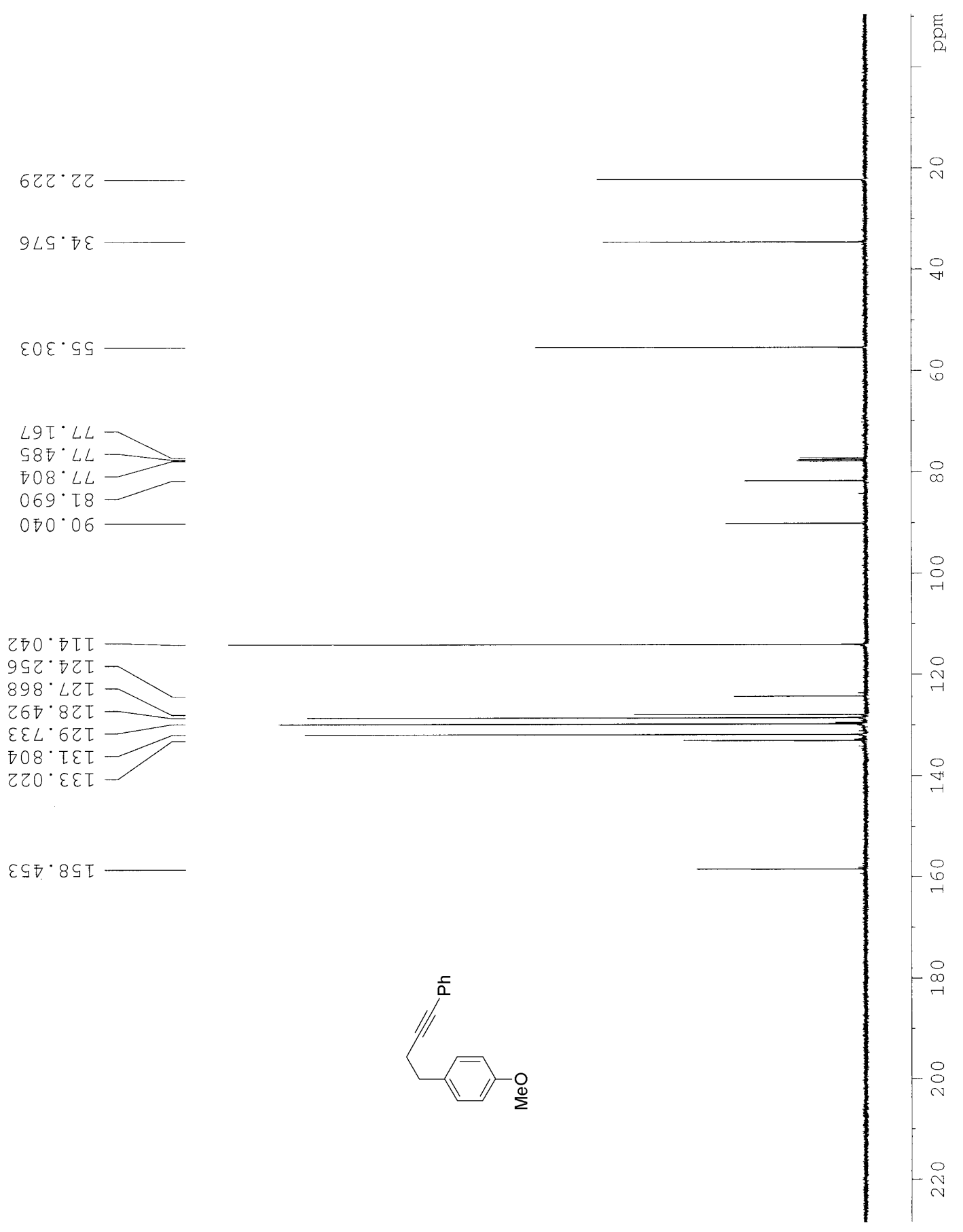
$000 \cdot 0-\square$
$0 \angle 0^{\circ} 0$
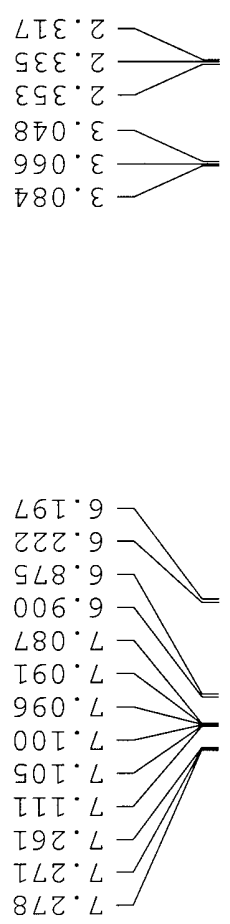

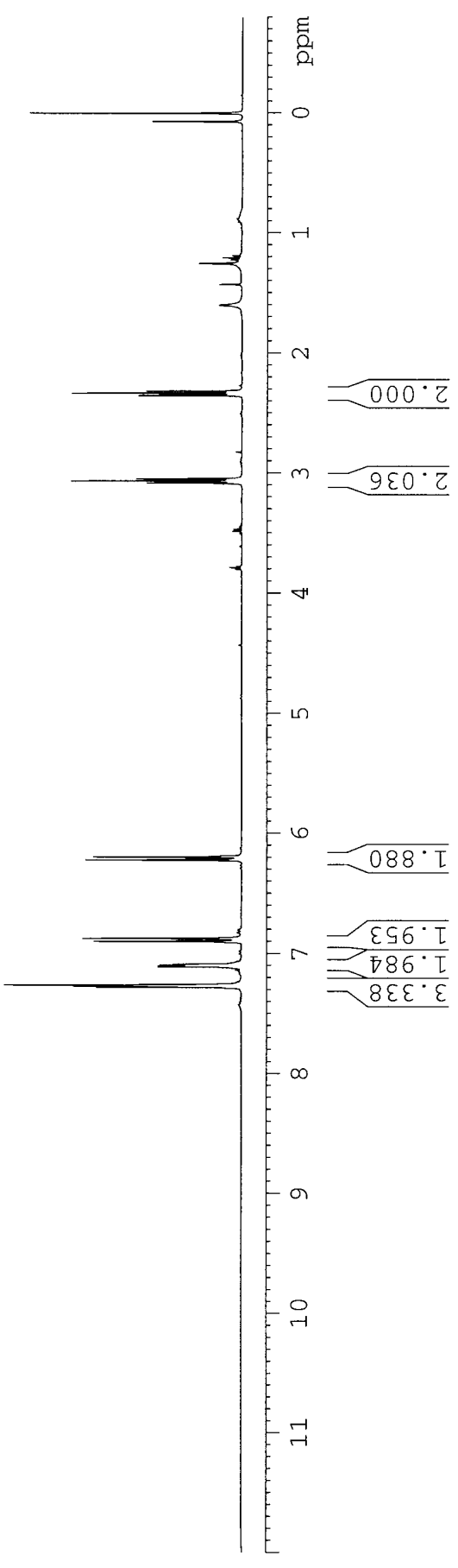

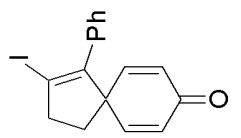




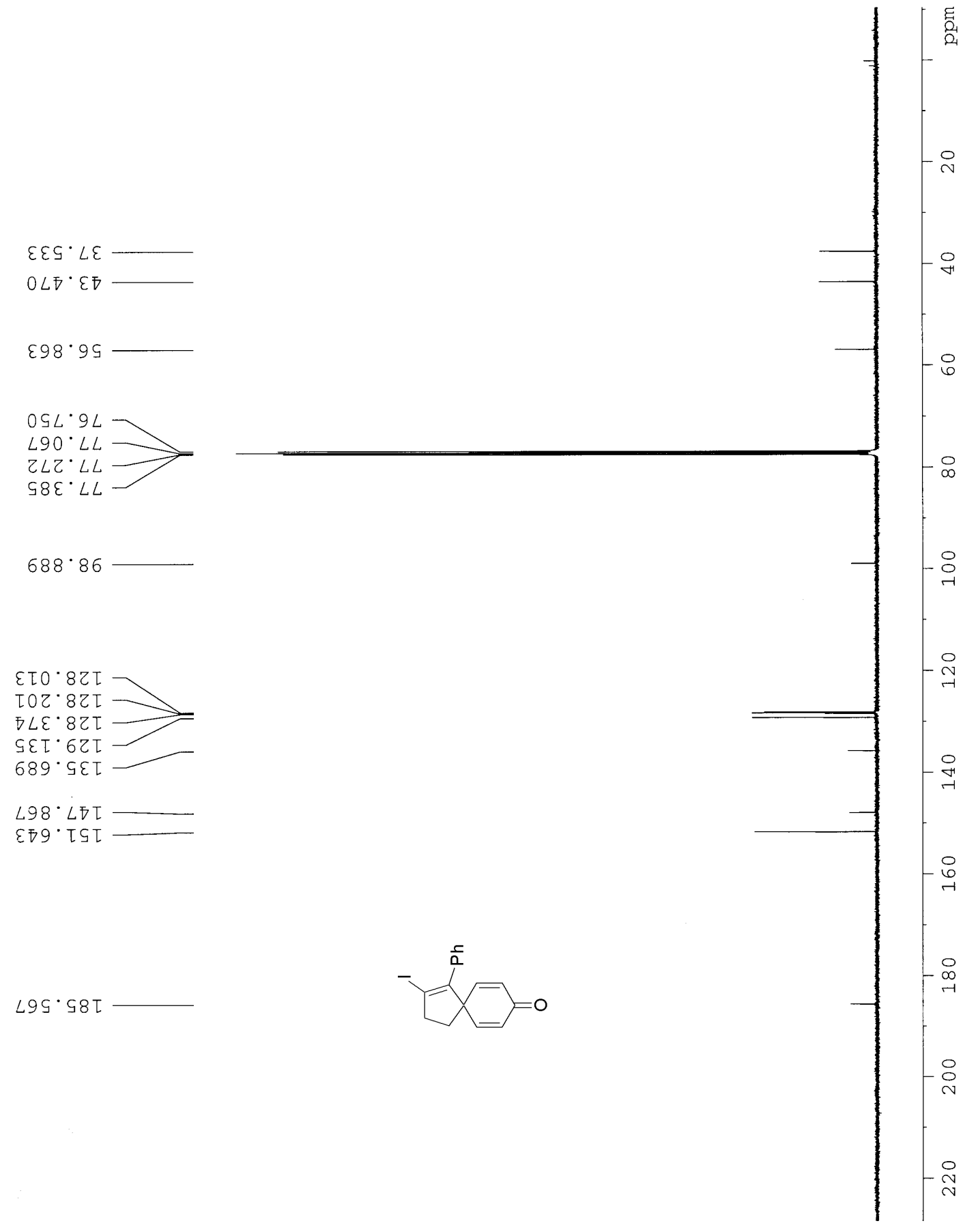

ชู 
$000 \cdot 0-$

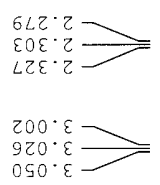

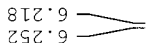

$292 \cdot 9$
$206 \cdot 9$ 986.97

951.4

E9I. $L$

$\angle 8 \mathrm{I} \cdot L$

$\varepsilon 92 \cdot L$

$9 L 2 \cdot L]$
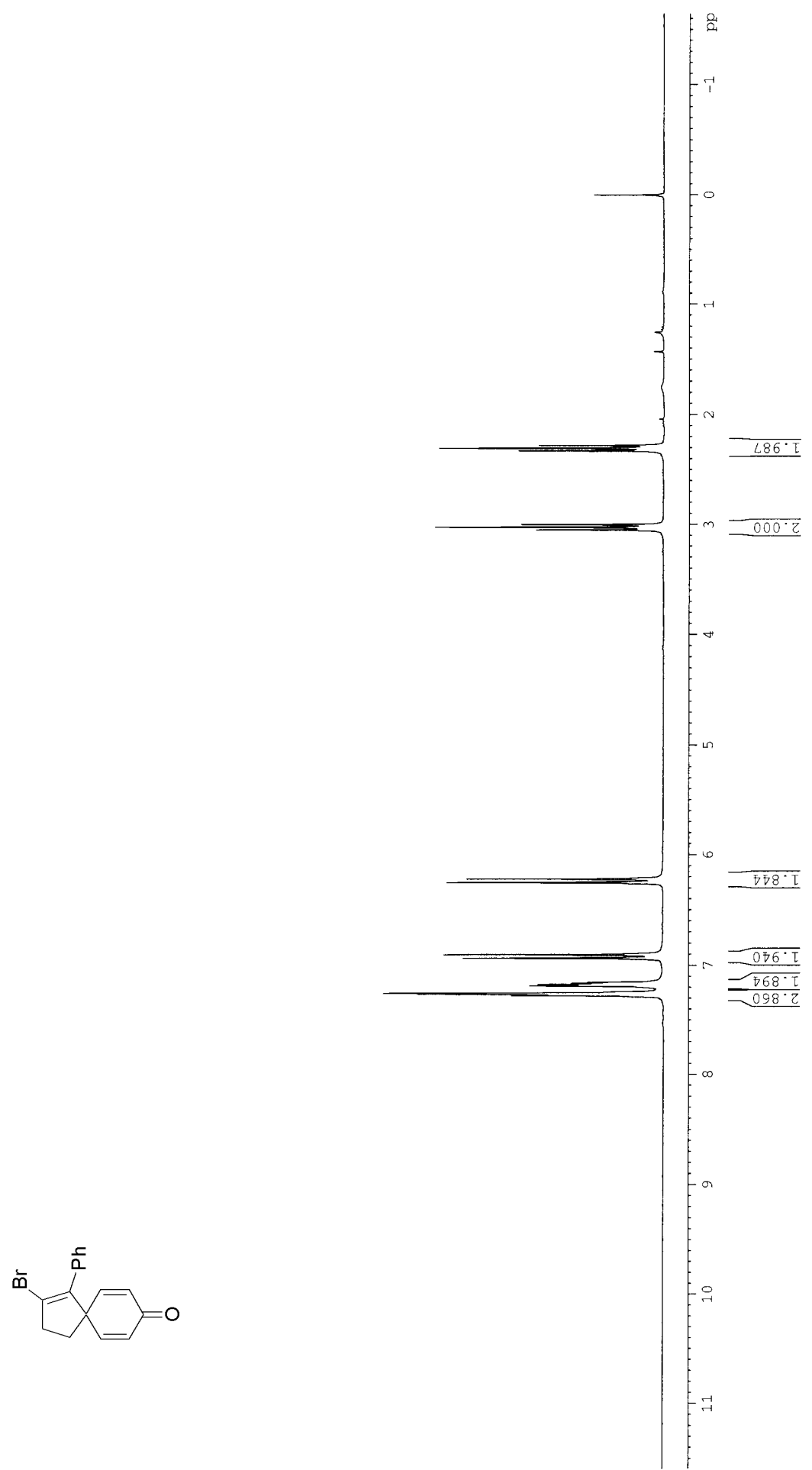

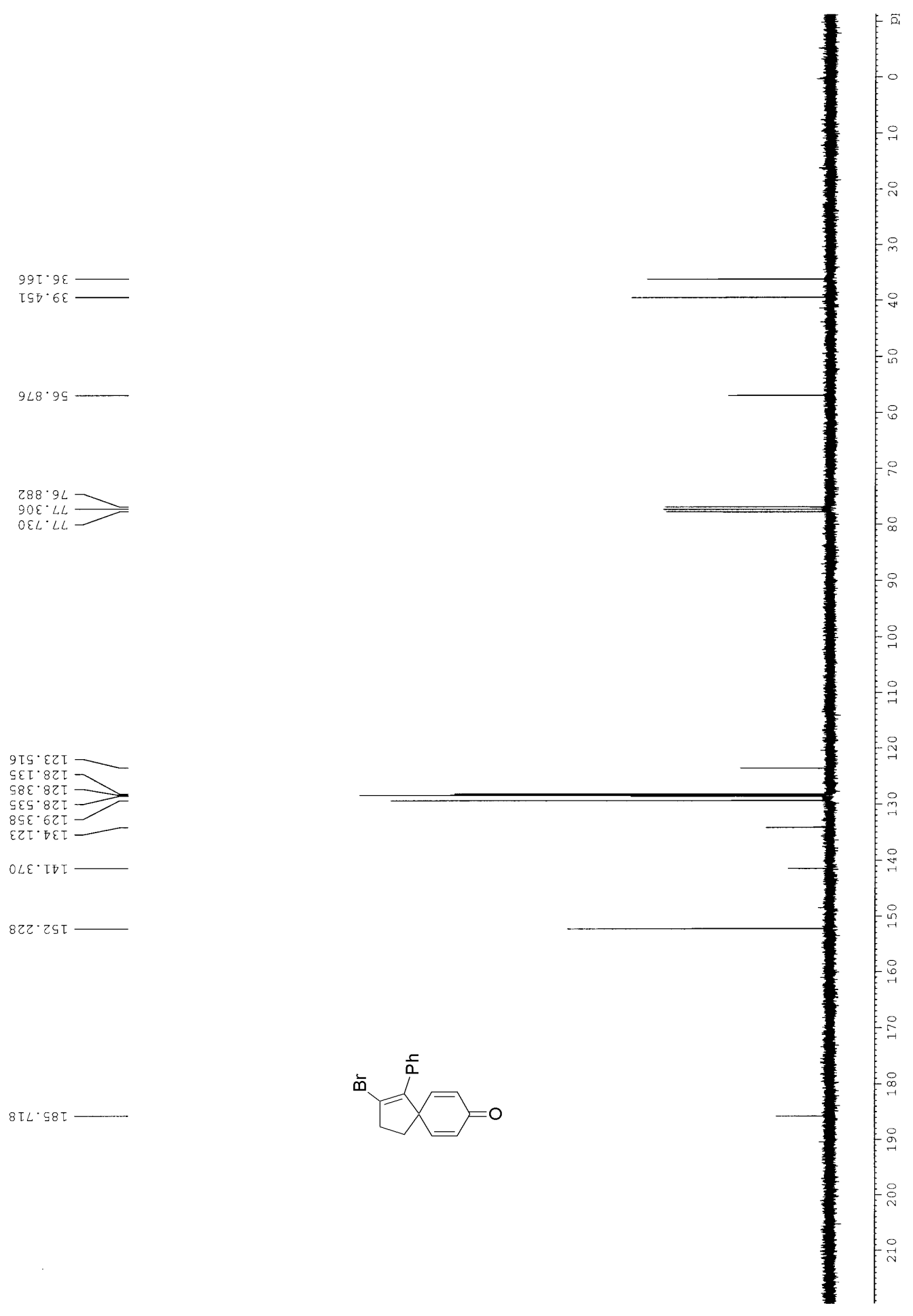

ऽ 

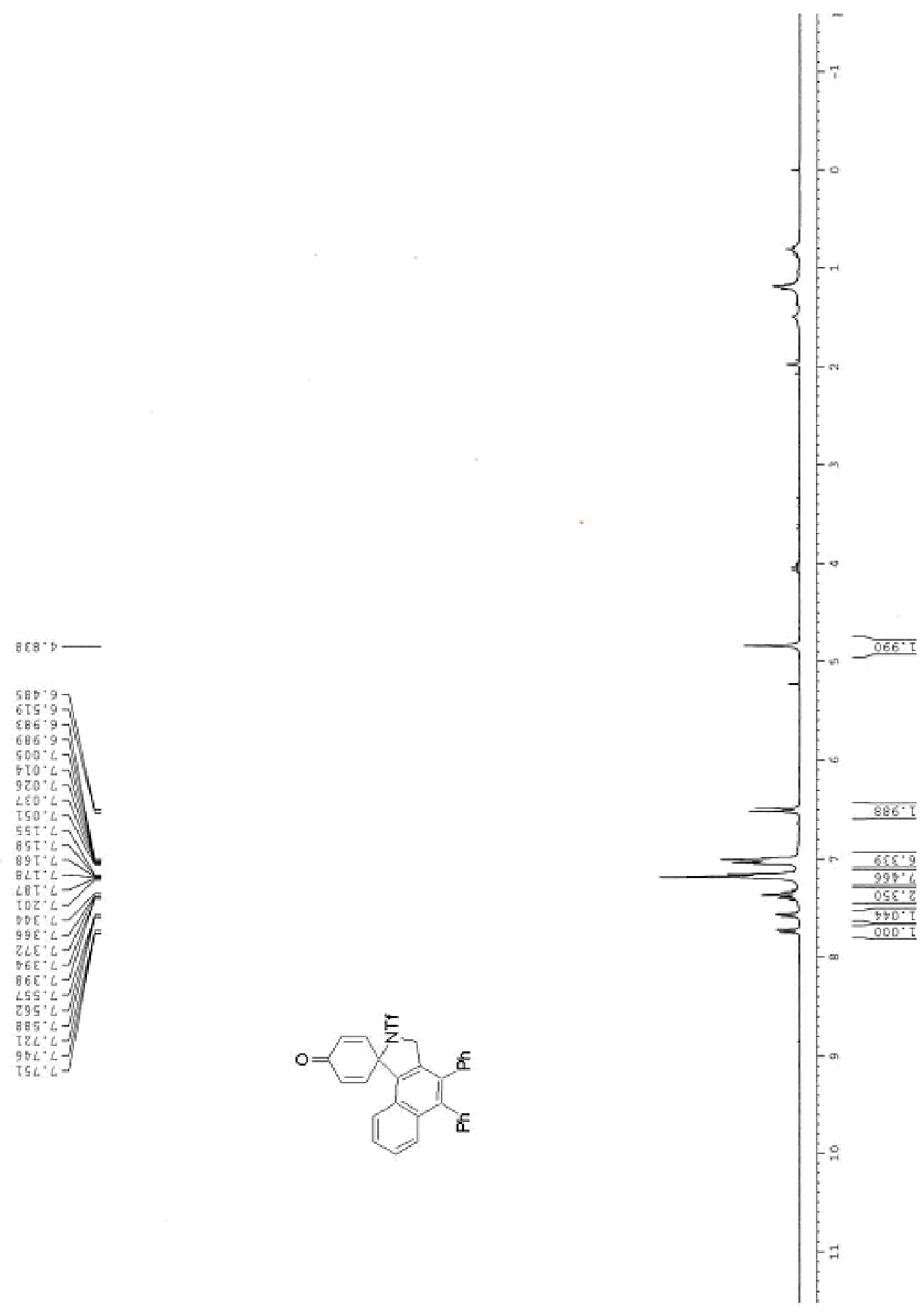


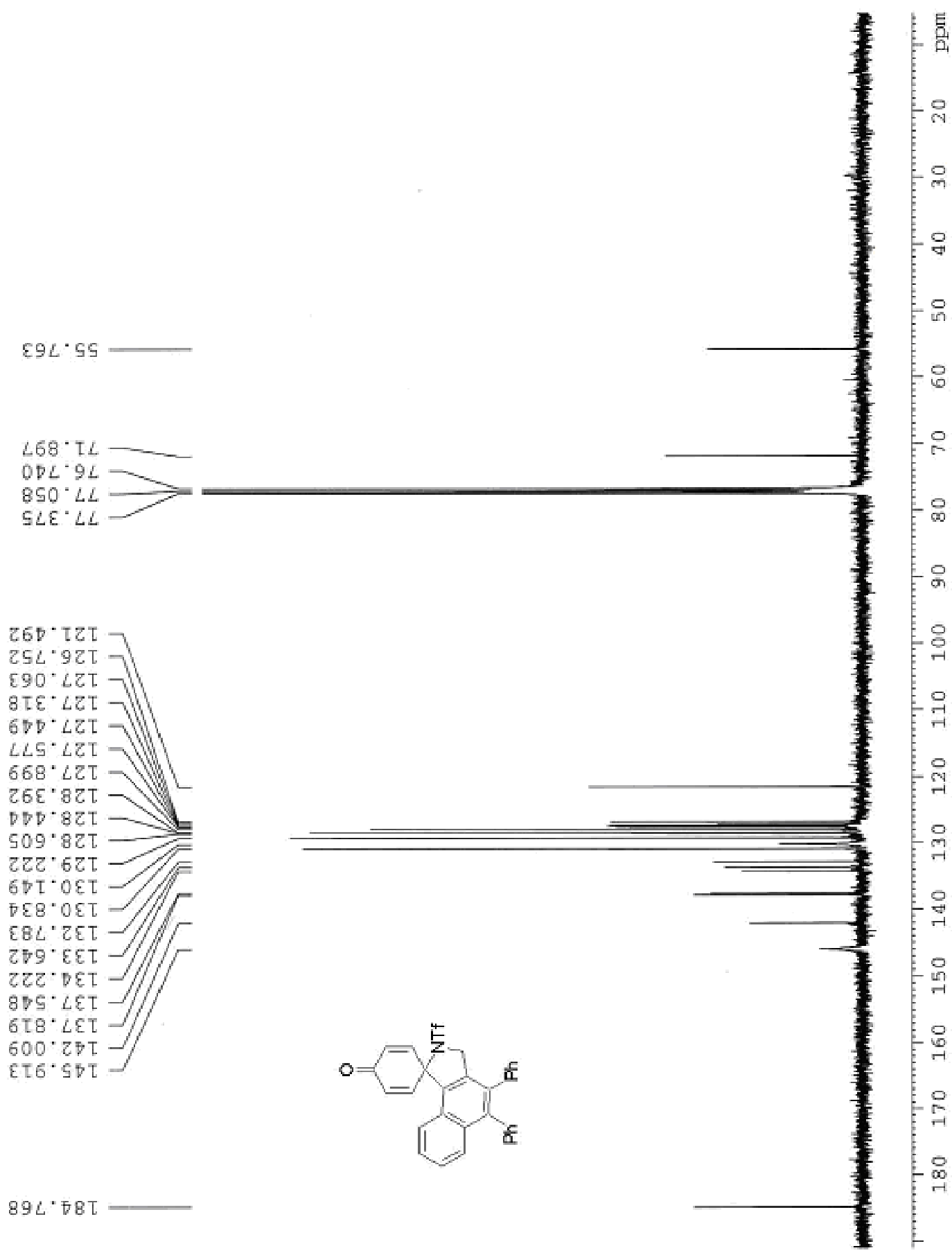

¿ 